\title{
Predictions of $\mathrm{PuO}_{2}$ and Tracer Compound Release from ISV Melts
}

\author{
August W. Cronenberg
}

Bichard A. Callow

Published April 1992

\section{Idaho National Engineering Laboratory \\ EG\&G Idaho, Inc. \\ Idaho Falls, Idaho 83415}

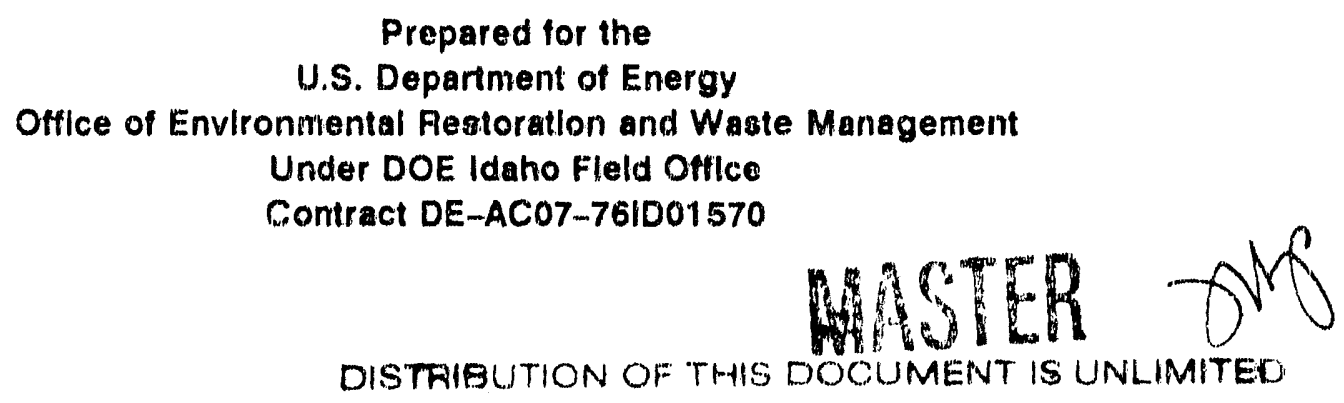

a. Engincering Science and Analysis, 8100 Mountain Road, NE, Albuquerque, New Mexico, 87110. 


\section{Predictions of $\mathrm{PuO}_{2}$ and Tracer Compound Release from ISV Melts

\author{
EGG-WTD-10172
}

Prepared by:

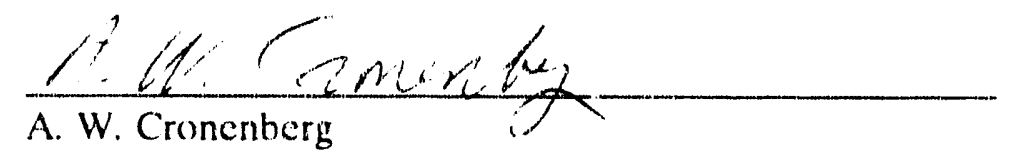

$\frac{2 / z_{i}}{\text { Date }}$

Revicwed by:

R. A. Callow

$\frac{1 / s / i j}{\text { Dale }}$

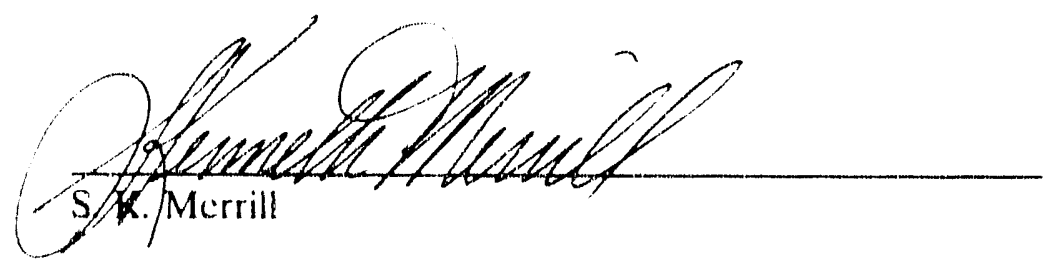

$\frac{4 / 9 / 92}{\text { Datc }}$ 


\section{ABSTRACT}

Two field tests were conducted at the Idaho National Engincering Laboratory (INEL) to assess in situ vitrification (ISV) suitability for long-term stabilization of buried radioactive waste. Both tests contained rare-earth oxide tracers $\left(\mathrm{D}_{2} \mathrm{O}_{3}, \mathrm{Yb}_{2} \mathrm{O}_{3}\right.$, and $\mathrm{Th}_{4} \mathrm{O}_{7}$ ) to simulate the presence of plutonium in the form of $\mathrm{PuO}_{2}$. In the first test, Intermediate Field Test (IFT)-1, approximately $4-\%$ release of tracer material occurred during soil melting and associated off-gassing, while essentially nil release was observed for the second experiment (IFT-2) for which off-gassing was much reduced. This report presents an evaluation of the IFT test data in terms of governing release processes.

Prediction of tracer release during ISV melting centered on an assessment of threc potential transport mechanisms, (a) tracer diffusion through stagnant pool, (b) tracer transport by convective currents, and (c) tracer carry-ofl by escaping gas bubbles. Analysis indicates that tracer release by escaping gas is the dominant release mechanism, which is consistent with video records of gas bubble escape from the ISV melt surface.

Quantitative mass transport predictions were also made for the IFT-1 test conditions, indicating similarity between the 4-\% release data and calculational results at viscosities of $\approx 30(0)$ poise and tracer diffusivities of $\approx 10^{-6} \mathrm{~cm}^{2} / \mathrm{s}$. Since $\mathrm{PuO}_{2}$ has similar chemical and transport (diflusivity) propertics as the rare-earth tracers used in the IFT experiments, release of $\mathrm{PuO}_{2}$ is predicted for similar off-gassing conditions. Reduced off-gassing during ISV would thus be expected to improve the overall retention of heavy-oxides within vitrilied soil. 


\section{EXECUTIVE SUMMARY}

As part of Department of Energy (DOE) efforts at remediation of waste disposal sites at the Idaho National Enginecring Laboratory (INEL) and other DOE-operaled lacilities, a comprehensive in situ vitrification (ISV) testing program is being conducted to assess ISV suitability for long-term stabilization of buried radioactive waste. The process uses electrical resistance heating 10 melt contaminated soil or buried waste in place, which upon resolidification lixes the waste into a glass-like form. Although the feasibility of the ISV process has been demonstrated, concerns exist that small quantities of transuranics may migrate to the melt surface during melting, requiring process technology development to capture any released transuranic material.

To assess process suilability and overall technical issues, two Intermediate Field Tests (XFT) were conducted at the INEL. Both tests contained rare-earth oxides (tracers: dysprosium oxide$\mathrm{Dy}_{2} \mathrm{O}_{3}$, ytterbium oxide- $\mathrm{Y}_{2} \mathrm{~b}_{2} \mathrm{O}_{3}$, and terbium oxide- $\mathrm{Th}_{4} \mathrm{O}_{7}$ ) to simulate the presence of plutonium in the form of $\mathrm{PuO}_{2}$. In the first test, IFT-1, approximately 4-\% release of tracer material occurred during soil melting and associated off-gassing. Essentially nil release was observed in the second experiment (IFT-2) for which off-gassing was much reduced. This report assesses phenomena which could explain these differences in release behavior.

Prediction of tracer release during ISV melting centers on an assessment of three potential transport mechanisms, (a) tracer diffusion through stagnant pool, (b) tracer transport by convective currents, and (c) tracer carry-off by escaping gas bubbles. Order-of-magnitude release times were estimated for three mechanisms, indicating carry-off of tracers by escaping gas bubbles to be the dominant release mechanism. Evidence of such bubble escape has been obtained from video records oblained during ISV melting, indicating the bursting of vapor domes at the melt surface both during initial dryout of soil, as well as at times when buried waste was exposed to melting. Thus, more detailed investigation of tracer release due to gas escape from the me!t was pursued.

Quantitative mass transport predictions were made for the IFT. 1 test conditions, assuming tracer molecular carry-off by gas bubble rise through the melt. Phenomena investigated include characterization of bubble rise requirements for release from the melt, assessment of the iFT-1 tracer concentration conditions and molecular diffusivities within $\mathrm{SiO}_{2}$-based melt, molecular solubility criteria, and an evaluation of various mass transfer correlations applicable 10 bubble rise through liquids. Estimates indicate bubte diameters of $\approx 0.5-5.0 \mathrm{~cm}$, with tracer and $\mathrm{PuO}_{2}$ molecular diffusivities of $\approx 0.2-\left(0.810^{-6} \mathrm{~cm}^{2} / \mathrm{s}\right.$. Predictions also indicate IFT-1 tracer concentrations on the order of 0.0095 w $1-\%$, while solubility data indicate that the rare-earth oxides and $\mathrm{PuO}_{2}$ would dissolve to at least $1.0 \mathrm{wt}-\%$ in basaltic melts. Thus, the IFT-1 tracers were assumed to be dissolved in the melt, so that mass transport correlations were employed for molecular carry-off due to bubble escape from the melt.

Calculational results indicate tracer release fractions ranging from 4.\% 10 20.\%, depending on soil properties (viscosity, diflusivity) and bubble size. A "best estimate prediction" yields a release: fraction of about $4.5-\%$ for the IFT-1 test conditions, at soil viscositics of $\approx 300$ poise, tracer molecular diffusivities of $\approx 0.10 \mathrm{E}-6 \mathrm{~cm}^{2} / \mathrm{s}$, and bubbles diameters of $1 \mathrm{~cm}$. Since these parameters appear to be physically realistic, tracer molecular transport by off-gassing is judged to be the 
governing mechanism for the IFT-1 test conditions. Since $\mathrm{PuO}_{2}$ has similar chemical and transpost (diffusivity) properties as the rare-earth oxides, release of $\mathrm{PuO}_{2}$ is also predicted for the IFT-1 lest conditions.

An attempt was also made to account for the diflerences in tracer release behavior noted tor the IFT-1 and IFT-2 experiments. Although IFT-2 contained potentially more volatile waste than IFT-1, the extent of gas release in IFT-2 was assessed to be much less than in IFT-1, based on oflgassing behavior deduced from hood temperature and vacuum pressure measurements. Note also that although quiescent gas release occurred continuously over the entire ISV inelt process, transient large-volume gas release was also observed. For such transient gas release, standard mass transport correlations do not apply. Nevertheless, no matter which gas escape mechanism dominates (bubble escape or slug-lype/large-volume gas release), the IFT test data and analysis clearly suggest tracer mass transport and release tied to some form of gas escape. Control of off-gassing during ISV can thus be expected to improve the overall retention of transuranic and rare-carth oxides. 


\section{CONTENTS}

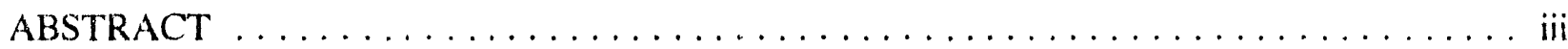

EXECUTIVE SUMMARY $\ldots \ldots \ldots \ldots \ldots \ldots \ldots \ldots \ldots \ldots \ldots \ldots \ldots \ldots$

ACRONYMS $\ldots \ldots \ldots \ldots \ldots \ldots \ldots \ldots \ldots \ldots \ldots \ldots \ldots \ldots \ldots \ldots \ldots \ldots \ldots \ldots \ldots \ldots$

1. INTRODUCTION $\ldots \ldots \ldots \ldots \ldots \ldots \ldots \ldots \ldots \ldots \ldots \ldots \ldots \ldots \ldots \ldots$

2. REVIEW OF ISV TRACER RELEASE DATA $\ldots \ldots \ldots \ldots \ldots \ldots \ldots \ldots \ldots$

2.1 Overview of the INEL IFT Experiments $\ldots \ldots \ldots \ldots \ldots \ldots \ldots \ldots \ldots \ldots \ldots$

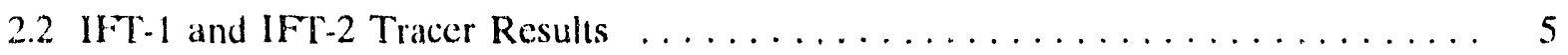

2.2 .1 IFT-1 Results $\ldots \ldots \ldots \ldots \ldots \ldots \ldots \ldots \ldots \ldots \ldots \ldots \ldots \ldots$

2.3) IFT-2 Test and Tracer Results $\ldots \ldots \ldots \ldots \ldots \ldots \ldots \ldots \ldots \ldots \ldots$

2.4 Summary of IFT Tracer Release Data $\ldots \ldots \ldots \ldots \ldots \ldots \ldots \ldots \ldots \ldots \ldots$

3. OVERVIEW OF MASS TRANSPORT DURING ISV MELTING $\ldots \ldots \ldots \ldots \ldots 12$

3.1 Diffusion Controlled Mass Transport $\ldots \ldots \ldots \ldots \ldots \ldots \ldots \ldots \ldots \ldots \ldots \ldots$

3.2 Convection Controlled Mass Transport $\ldots \ldots \ldots \ldots \ldots \ldots \ldots \ldots \ldots \ldots \ldots$

3.3 Mass Transfer Due to Bubble Rise $\ldots \ldots \ldots \ldots \ldots \ldots \ldots \ldots \ldots \ldots \ldots$

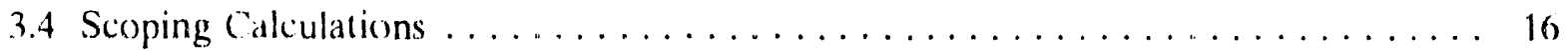

4. PREDICTIONS OF ISV TRACER RELEASE DUE TO BUBBLE RISE $\ldots \ldots \ldots \ldots .19$

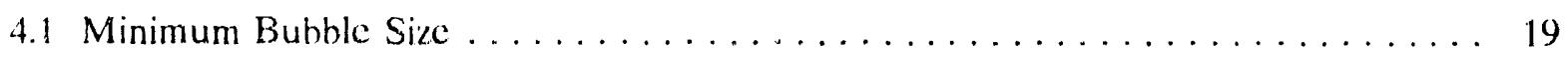

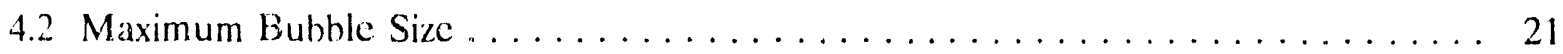

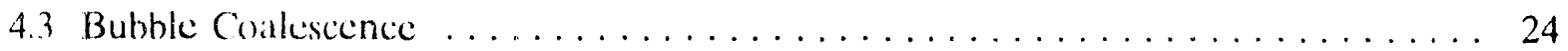

4.4 Mass Transport Coefficient for Bubble Rise $\ldots \ldots \ldots \ldots \ldots \ldots \ldots \ldots \ldots \ldots$

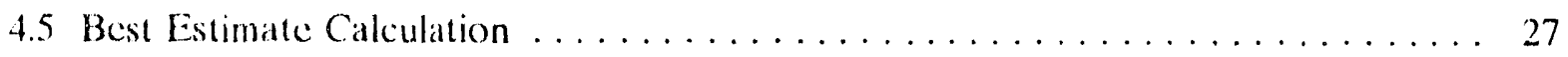

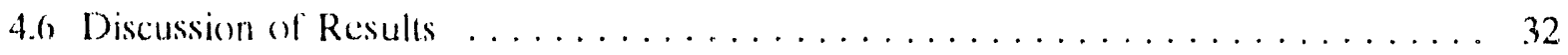

5. COMPARISON OF THE IFT-1 AND IFT-2 TRACER RELEASE TRENDS $\ldots \ldots \ldots 37$ 


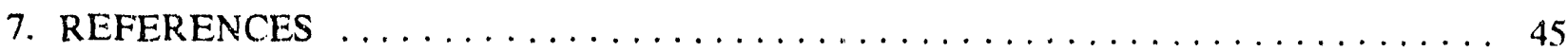

APPENDIX A-Soil Melt Properties for Transport Modeling $\ldots \ldots \ldots \ldots \ldots \ldots \ldots$ A-1

APPENDIX B-Diffusivity Estimates for Mass Transport Analysis $\ldots \ldots \ldots \ldots \ldots \ldots \ldots$ B-1

\section{FIGURES}

1. Illustration of in situ vitrification processing of buried waste $\ldots \ldots \ldots \ldots \ldots \ldots$

2. Illustration of waste configuration and tracer placernent location in IFT-1 and IFT'-2 .. 4

3. Depth of soil melting, deduced from average electrode depth data $\ldots \ldots \ldots \ldots \ldots$

4. Measured off-gas flow rate and hood plenum temperature during the IFT-1 experiment ................................ 7

5. Measured oxygen $\left(\mathrm{O}_{2}\right)$ and $\mathrm{CO}$ hood concentrations during the IFT-1 experiment $\ldots \ldots 8$

6. Comparison of off-gassing behavior noted in tests IFT-1 and IFT-2 $\ldots \ldots \ldots \ldots$

7. Illustration of potential mass transport modes for quiescent, dynamic, and

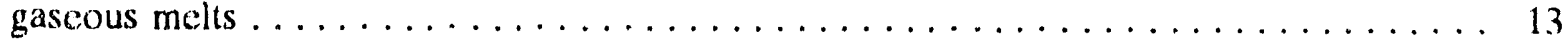

8. Simple force balance on a rising gas bubble in a viscous liquid $\ldots \ldots \ldots \ldots \ldots \ldots$

9. Illustration of buoyant rise versus circular convective curren for bubble entrainment _. 20

10. Summary of ISV IFT -1 test conditions $\ldots \ldots \ldots \ldots \ldots \ldots \ldots \ldots \ldots \ldots \ldots \ldots$

11. Photographic evidence of bubble bursting at ISV melt surface $\ldots \ldots \ldots \ldots \ldots \ldots \ldots$

12. Illustration of relative burial positioning for tracer and vaporous matcrials for the IFT-1 and IFT -2 experiments $\ldots \ldots \ldots \ldots \ldots \ldots \ldots \ldots \ldots \ldots$

13. Comparison of measured hood pressure and temperatures noted in IFT-1 and IFT-2 . . 41

14. Illustration of gas escape by bubble rise, versus transient slug-type gas release $\ldots \ldots \ldots 42$

\section{TABLES}

1. Waste inventory in the IFT-1 and IFT -2 experiments $\ldots \ldots \ldots \ldots \ldots \ldots$

2. Summary of soil melt properties and system parameters $\ldots \ldots \ldots \ldots \ldots \ldots \ldots \ldots$ 
3. Estimation of time constant for diffusion-governed release $\ldots \ldots \ldots \ldots \ldots \ldots \ldots$

4. Estimation of time constant for free convection $\ldots \ldots \ldots \ldots \ldots \ldots \ldots \ldots \ldots$

5. Estimation of time constant for bubble rise $\ldots \ldots \ldots \ldots \ldots \ldots \ldots \ldots \ldots$

6. Estimation of minimum bubble size for escape from ISV melts $\ldots \ldots \ldots \ldots \ldots \ldots 22$

7. Estimation of maximum bubble size for ISV melts $\ldots \ldots \ldots \ldots \ldots \ldots \ldots \ldots \ldots$

8. Estimation bubble morphology characteristics due to coalescence $\ldots \ldots \ldots \ldots \ldots$

9. Calculational methodology for estimation of overall mass release fraction $\ldots \ldots \ldots 28$

10. Best estimate calculational of tracer release fraction for the IFT-1 experiment $\ldots \ldots \ldots 29$

11. Estimation of various mass transfer correlations for the Sherwood number an mass transfer coefficient $\ldots \ldots \ldots \ldots \ldots \ldots \ldots \ldots \ldots \ldots \ldots \ldots \ldots \ldots \ldots \ldots$

12. Comparison of predicted and published diffusivities for molten soil materials $\ldots \ldots \ldots 35$

13. Waste inventory in the IFT-1 and IFT-2 experiments $\ldots \ldots \ldots \ldots \ldots \ldots \ldots \ldots$ 


\section{ACRONYMS}

DOE Department of Energy

HEPA high-efficiency particulate air (filter)

IFT Intermediate Field Test

INEL. Idaho National Engineering Laboratory

ISV in situ vitrification

PNL Pacific Northwest Laboratory 


\section{Predictions of $\mathrm{PuO}_{2}$ and Tracer Compound Release from ISV Melts}

\section{INTRODUCTION}

As part of Department of Energy (DOE) mandated efforts at improving long-term stabilization of buried radioactive waste at DOE-operated sites, a comprehensive in situ vitrification (ISV) testing/feasibility program is being conducted at the Idaho National Enginecring Laboratory (INEL) to assess ISV suitability for buried waste remediation. Figure 1 illustrates the basic features of the process where electrical resistance heating is employed to melt buried waste in place, which upon resolidification fixes the waste into a glass-like form. During soil melting, organic components are pyrolyzed resulting in formation of gaseous byproducts $\left(\mathrm{CO}, \mathrm{CO}_{2}\right.$, and $\left.\mathrm{H}_{2} \mathrm{O}\right)$, which migrate through the melt to the upper surface. Combustible gases released from the melt burn within the air environment of a cover hood, which acts as a collection system. Collected gases and combustion byproducts are then sent to an on-iine filtration and scrubbing system to ensure that any emissions meet regulatory requirements.

Because of the high temperatures involved $\left.(>150)^{\circ} \mathrm{C}\right)$, no residual organics remain within the vitrified product. For heavy metals, such as uranium and plutonium, the desirable behavior is immobility during ISV melting, so that upon melt cooling, complete relention within the recrystallized glass-like product occurs. However, alteration from ideal behavior can occur; processes such as dynamic off-gassing and melt ejection can exert an adverse influence on overall waste retention characteristics.
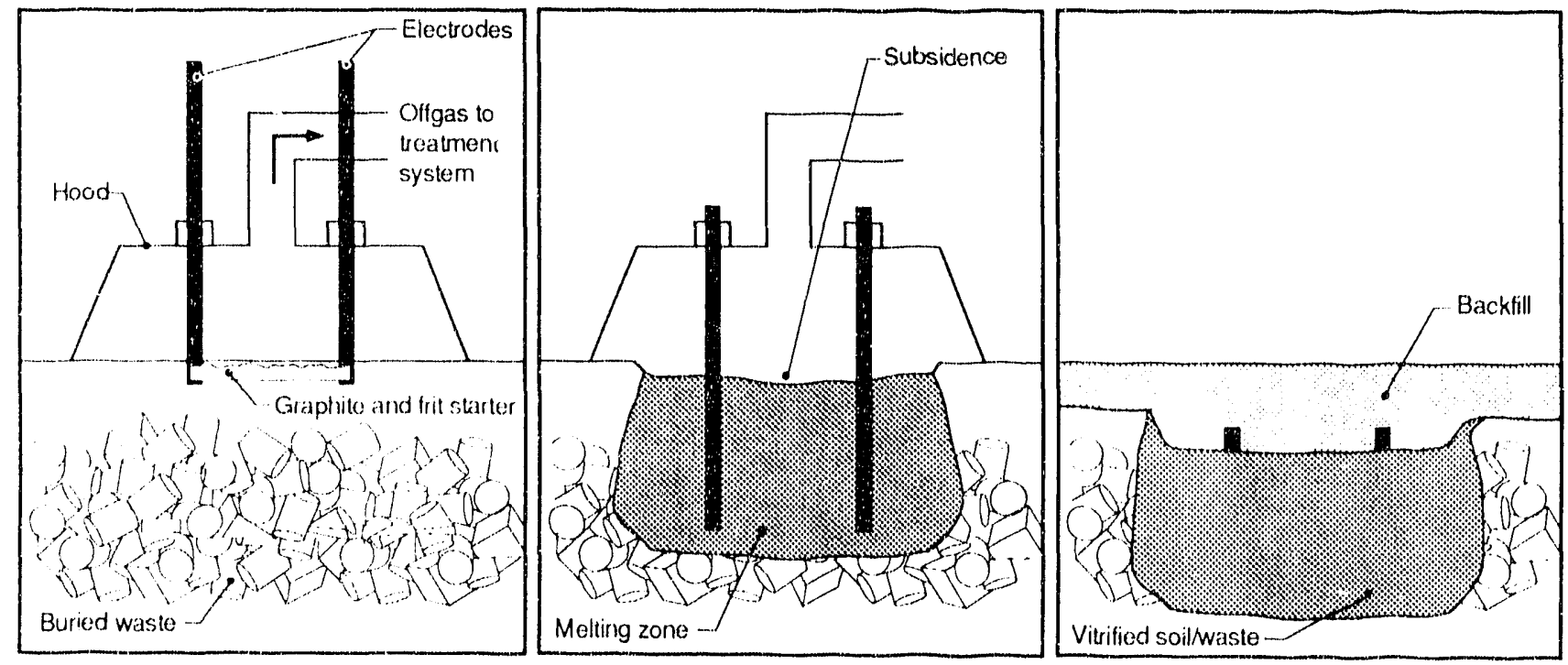

T910811

Figure 1. Illustration ot in situ vitrification processing of buried waste. 
To assess ISV suitability to remediation of buried waste, two Intermediate Field Tests (IFT) have been conducted at the INEL to date. ${ }^{1}$ In these tests small quantities of rare-carth oxides (tracer material: $\mathrm{Dy}_{2} \mathrm{O}_{3}, \mathrm{Yb}_{2} \mathrm{O}_{3}$, and $\mathrm{Tb}_{4} \mathrm{O}_{7}$ ) were added to the test pits to simulate plutonium (in the form of $\mathrm{PuO}_{2}$ ) behavior. The interest in plutonium stems from the necessity to protect ISV workers and equipment from its release during soil melting. Some data are available on plutonium (Pu) release from ISV melts, which however is limited to vitrification of contaminated soils. ${ }^{2}$ The interest in the INEL studies is the application of the ISV process to remediation of buried waste canisters which contain sludge and combustible materials contaminated with trace quantities of plutonium. It is from this perspective that small amounts of rare-earth tracer materials were added to the INEL test pits to simulate plutonium behavior. ${ }^{3}$

In the first experiment, IFT-1, three rare-earth tracers $\left(\mathrm{Dy}_{2} \mathrm{O}_{3}, \mathrm{Yb}_{2} \mathrm{O}_{3}\right.$, and $\left.\mathrm{Tb}_{4} \mathrm{O}_{7}\right)$ were added to the test pit; while in the second experiment, IFT-2, only $\mathrm{Dy}_{2} \mathrm{O}_{3}$ was used to simulate $\mathrm{PuO}_{2}$ behavior. Data from IFT-1 indicate tracer release at $\approx 4-\%$ during soil melting and associated offgassing; while essentially nil release was observed for IFT-2 where off-gassing was much reduced. Thus, questions arise as to the conditions governing tracer release and whether the tracers empioyed adequately simulate the chemical/transport properties of $\mathrm{PuO}_{2}$ in ISV environments. These questions are addressed in this report, which is structured as follows.

The IFT test conditions and release data are first summarized in Section 2, followed by anailysis of potential mass transport mechanismis from ISV melts (Section 3), namely diffusion through a stagnant pool, mass transport by convective currents, and molecular release by escaping gas bubbles. Analysis indicates that tracer carry-off by escaping gas is the dominant release mechanism for ISV melt conditions; thus, a more in-depth study of tracer release by off-gassing is presented in Section 4. The IFT- 1 and IFT-2 test data are then compared in Section 5 , in light of differences in tracer release and off-gassing behavior noted between these two tests. Conclusions are then summarized in Section 6. 


\section{REVIEW OF ISV TRACER RELEASE DATA}

During the summer of 1990), (wo field experiments, reforred to as the Intermediate Fied Test (IFT) series, were conducted at the INEL to investigate the application of in silu vitrification (ISV) 10 processing of buried waste. ${ }^{4}$ It was proposed that tracer materials be added to each tost pit. to act es surrogates for the assessment of potential transuranic (primarily plutonium, $\mathrm{Pu}$ ) release during ISV melking. To establish a basis for delinition of appropriate $\mathrm{Pu}$ surrogates, a review of $\mathrm{Pu}$ and rare-earth chemistry was conducted. ${ }^{5}$ Results indicated that at ISV temperatures $\left(>1500^{\circ} \mathrm{C}\right)$ and basalt melt compositions (see Appendix $\mathrm{A}$ ) a reducing environment (indicated by $\mathrm{Fe}^{+2} / \Sigma \mathrm{Fe}>0.9$ ) can be expectexf; thus, the most likely forms of $\mathrm{Pu}$ are $\mathrm{PuO}_{2}$ (oxidation state +4 ) and $\mathrm{Pu}_{2} \mathrm{O}_{3}$. A review of the chemistry for the rare earths indicates similar oxidation states, i.e., +2 to +4 in basalt melts. With respect to solubility sinilaritics, prior studies indicate that oxides of both $\mathrm{Pu}^{6}$ and the rare earths ${ }^{7,8}$ are soluble in iren-rich basalt to a least one percent by weight. This limit far excecds that which is expected for INEL-ISV conditions, so that similar solubility characteristics are indicated for $\mathrm{PuO}_{2}$ and such rare-earth oxides as $\mathrm{Dy}_{2} \mathrm{O}_{3}, \mathrm{Yb}_{2} \mathrm{O}_{3}$, and $\mathrm{Tb}_{4} \mathrm{O}_{7}$. Likewise, for basalt melts, similar molecular diffusivities (see Appendix $\mathrm{B}$ ) are predicted for $\mathrm{Dy}_{2} \mathrm{O}_{3}, \mathrm{Yb}_{2} \mathrm{O}_{3}, \mathrm{~Tb}_{4} \mathrm{O}_{7}$, and $\mathrm{PuO}_{2}$, On this basis, the rare-earth oxides of $\mathrm{Dy}_{2} \mathrm{O}_{3}, \mathrm{~Tb}_{4} \mathrm{O}_{7}$, and $\mathrm{Yb}_{2} \mathrm{O}_{3}$ were judged to have suitable chemical and transport properties as that of $\mathrm{PuO}_{2}$ (se. References 3 and 5) and, thus, were used in the INEL IFT experiments.

After ISV processing of the IFT test pits was complete, the amounts of tracers were measured in retrieved samples of vitrified soil, as well as at various locations within the collection hood, olf-gas piping surfaces, and in the scrub solution (collectively referred to as the off-gas collection system). Altiough quantitative determination of tracer amounts was hampered by sampling and analysis uncertaintics (see Reference 4), overall results indicate that the inajority of the rare-earth oxide tracers were retained in the vitrilied product. Nevertheless, 10 s of grams of tracer material (original inventory of individual tracers ar $1.0(0) .23(0) \mathrm{g})$ were found within the off-gas collection system for the IFT-1 experiment, corresponding to upwards of several percent of tracer material released from the ISV melt. In the IFT-2 experiment, nil amounts of tracer were found in the olf-gas collection system. As will te discussed, a more dynamic off-gassing process was noted for IFT-1 compared to IFT-2, which could have impacted sracer release behavior. It is also interesting to note that the IFT-1 release data are at odds with previously reported findings of essentially complete $\mathrm{PuO}_{2}$ retention $\therefore$ ring ISV processing of contaminated soil (see Reference 2). Thus, questions arise relating (n) tracer and transuranic release potential during ISV processing. One possibility, which is assessed in this report, is the influence that off-gassing can exert on overall transport behavior of dilute species within melts. The INEL IFT-1 and IFT-2 tracer release data are reviewed in this chapter, and form the basis of model predictions of tracer release presented later in this report.

\subsection{Overview of the INEL IFT Experiments}

Figure 2 illustrates the relative positioning of waste and tracers in the INEL. Intermediate Fick Fests (refered lo as IFr-1 and IF- T-2). Pertinent watste inverblory and configuration information are provided in Table 1. In the IFT" 1 lest, the amounts of tracer added to simulate watste cans containing, sludge, papericleth, melal. concrete, and wood were as follows: $\mathrm{Dy}_{2} \mathrm{O}_{3}=1.336 \mathrm{~kg}, \mathrm{~Tb}_{4} \mathrm{O}_{7}=$ $1.3 .37 \mathrm{~kg}$, and $\mathrm{Yb}_{2} \mathrm{O}_{3}=1.331 \mathrm{~kg}$. Unlike IFT-1, only one tracer was placed in the IFT-2 pit, $\mathrm{Dy}_{2} \mathrm{O}_{3}$ 

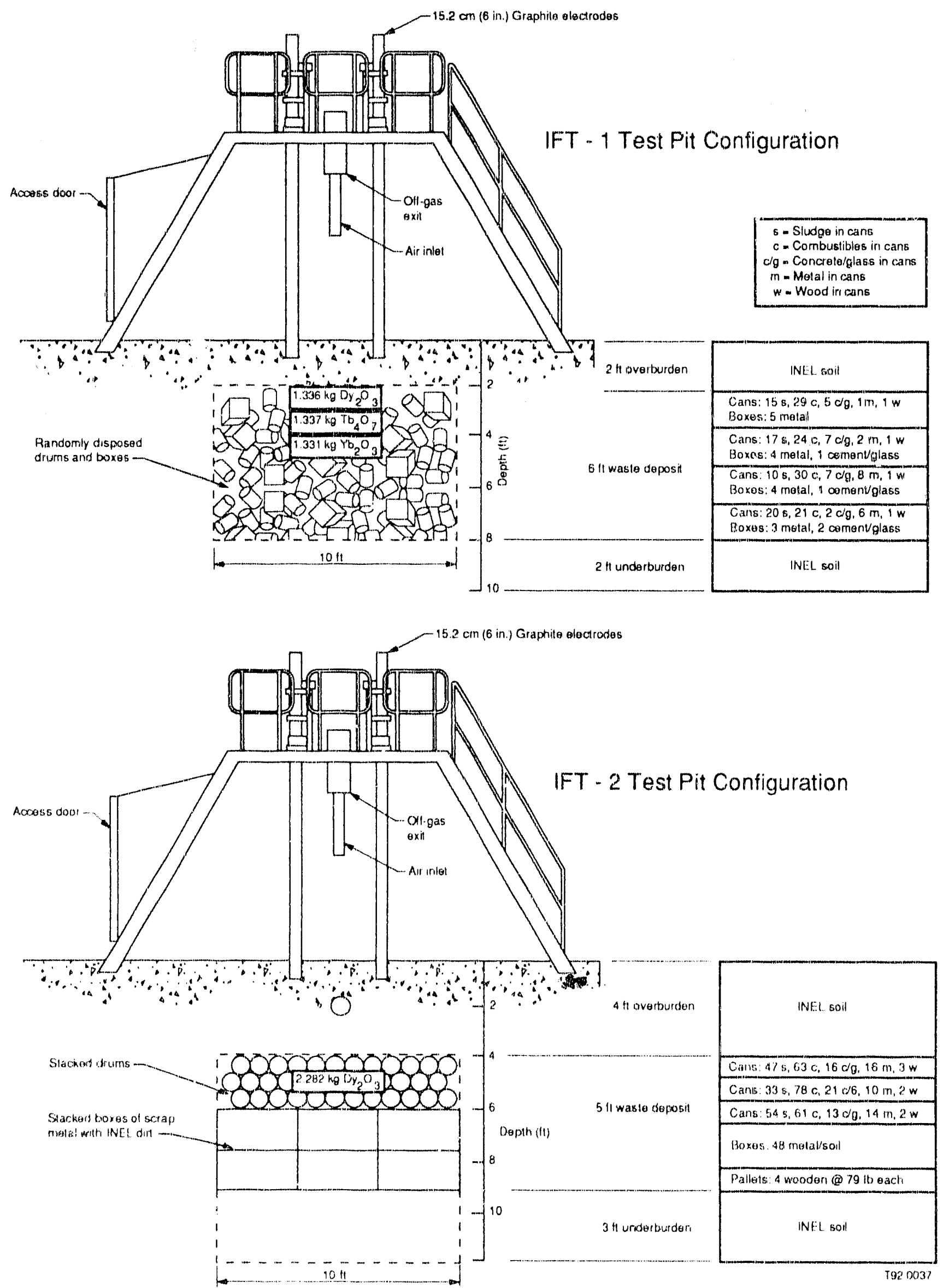

Figure 2. Illustration of waste configuration and tracer placement location in IFT-1 and IFT:2. 
Table 1. Waste inventory in the IFT-1 and IFT-2 experiments.

\begin{tabular}{|c|c|c|}
\hline & \multicolumn{2}{|c|}{ Inventories } \\
\hline Material & IFT-1 & HFT $=$ \\
\hline \multicolumn{3}{|l|}{ Waste Materials } \\
\hline Combustible & $666 \mathrm{lb}$ & $1,514 \mathrm{lb}$ \\
\hline Water & $478 \mathrm{lb}$ & $1,035 \mathrm{lb}$ \\
\hline FLOOR-DRI & $43 \mathrm{lb}$ & $94 \mathrm{lb}$ \\
\hline MICRO-CELL & $143 \mathrm{lb}$ & $308 \mathrm{lb}$ \\
\hline Metal & $2,473 \mathrm{lb}$ & $6,758 \mathrm{lb}$ \\
\hline Glass & $485 \mathrm{lb}$ & $237 \mathrm{lb}$ \\
\hline Concrete & $867 \mathrm{lb}$ & $600 \mathrm{lb}$ \\
\hline \multicolumn{3}{|l|}{ Tracers } \\
\hline $\mathrm{Dy}_{2} \mathrm{O}_{3}$ & $1.3 .36 \mathrm{~kg}$ & $2.282 \mathrm{~kg}$ \\
\hline $\mathrm{Tb}_{4} \mathrm{O}_{7}$ & $1.337 \mathrm{~kg}$ & $\ldots$ \\
\hline $\mathrm{Yb}_{2} \mathrm{O}_{3}$ & $1.331 \mathrm{~kg}$ & $\ldots$ \\
\hline Tracers (total) & $4.004 \mathrm{~kg}$ & $2 . \overline{282 \mathrm{~kg}}$ \\
\hline \multicolumn{3}{|l|}{ Soil } \\
\hline Soil Fill & $54,630 \mathrm{lb}$ & $49,963 \mathrm{lb}$ \\
\hline Soil Overburden & $2 \mathrm{ft}$ & $4 \mathrm{ft}$ \\
\hline
\end{tabular}

\subsection{IFT-1 and IFT-2 Tracer Results}

\subsubsection{IFT-1 Results}

The IFT-1 test was initiated on June 12, 1990, and had proceeded for approximately five hours when an electrode power cable failed at a melt depth of 46 to $51 \mathrm{~cm}$ (18 $1020 \mathrm{in})$. Upon cable replacement the test was restarted (on June 14th) at an essentially constant power of $300 \mathrm{~kW}$ for an additional 18 hours. During this time the overall rate of downward melt growth averaged $4.6 \mathrm{~cm} / \mathrm{h}$ $(1.8 \mathrm{in} . \mathrm{h})$, which includes the final 15 hours of operation during which the downward melt growth rate was significantly redued due $t o$ the electrical imbalances. The maximum achieved melt depth was approximately $240 \mathrm{~cm}(\approx 7.9 \mathrm{ft})$, with an electrode depth history as illustrated in Figure 3 . Final soil collapse (subsidence) was measured at approximately $1.4-2.0 \mathrm{~m}(4.5-6.5 \mathrm{ft})$, leaving a $0.4 \mathrm{~m}$ ( 18 in.) layer of glass in the bottom of the vitrified area. 


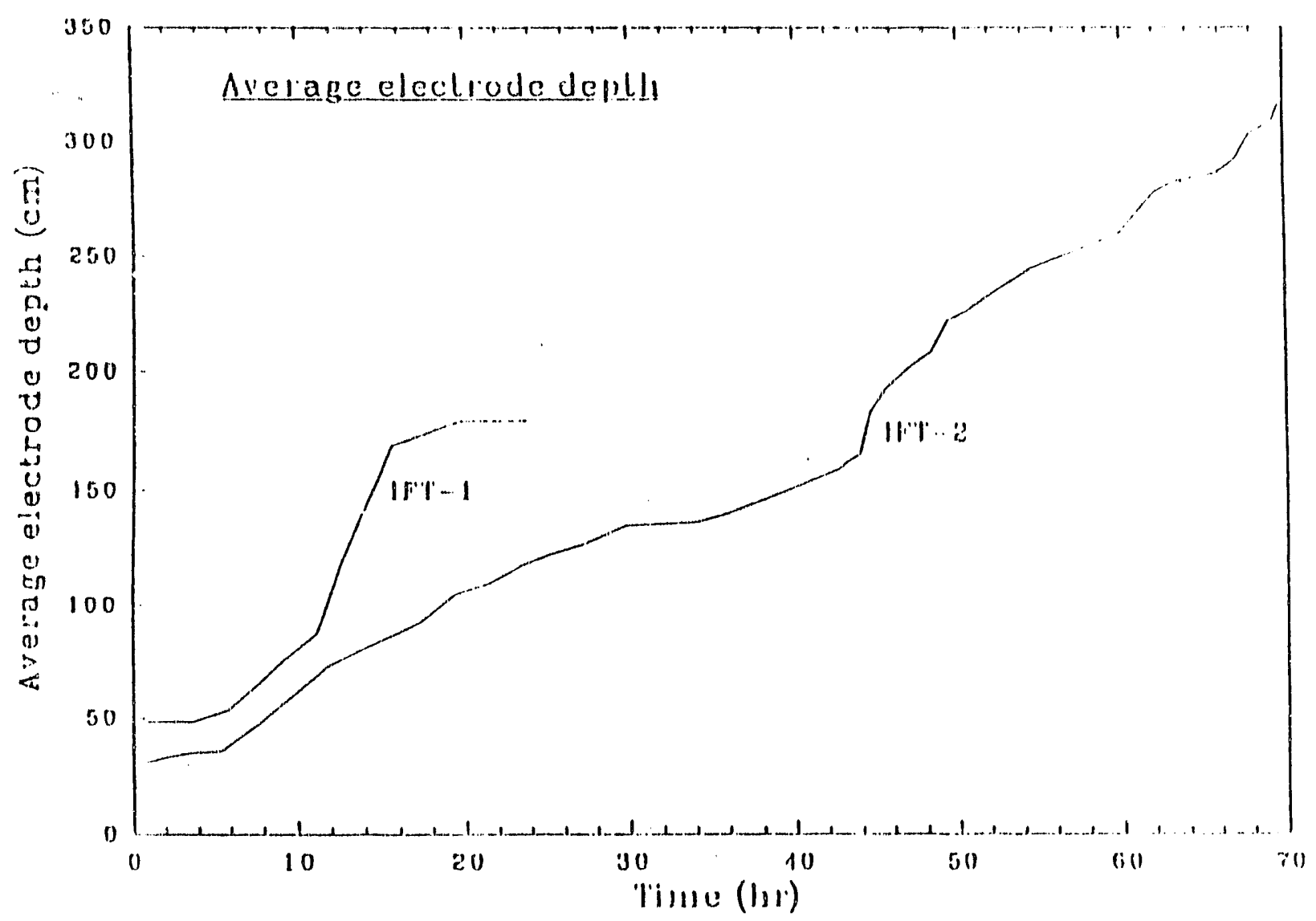

Figure 3. Depth of soil melting, deduced from average electrode depth data.

As indicated in Figure 4, gas released during the IFT-1 melt period occurred in 14 separate events, characterized by sharp temperature increases and/or pressure spikes in the off-gas collection hood. Concentrations of oxygen $\left(\mathrm{O}_{2}\right)$ and carbon monoxide $(\mathrm{CO})$ were monitored at the off-gas stack throughout the test. The oxygen concentration averaged between 20 and $21-\%$ during the test; however, short periods of reduced oxygen concentrations were measured at times consistent with gas releases from the melt and increased $\mathrm{CO}$ as a consequence of gas combustion in the hood. As shown in Figure 5, carbon monoxide concentrations ranged from 0.1 to $0.4 \%$, with occasional spikes greater than $0.4 \%$, up to a maximum of $1.1 \%$ at startup (associated with consumption of graphite starter). Several press ire spikes resulted in a slight decrease in the oxygen concentration but were not accompanied $b y$ increases in carbon monoxide. li .ollows that the gas release from ie melt in those cases was due to a release of steam from the sludge cans that contained water.

Tracer release data were assessed from samples of the retrieved (a) vitrified glass product, (b) confinement hood, (c) off-gas piping, (d) off-gas scrub solutions, (e) off-gas HEPA and inlet filters, (f) soil and sand used in pit preparations, and ( $\mathrm{g}$ ) soil adjacent to the vitrified glass product. Sampling strategies and detailed data are given in Reference 4, which can be summarized as follows. For present purposes, results are expressed in terms of the initial inventory of the respective rare earths, rather than their oxides as follows:

\begin{tabular}{cr} 
Oxide Inventory & Rare Earth Inventory \\
\hline $\mathrm{DyO}_{3}=1336 \mathrm{~g}$ & $\mathrm{Dy}=1164 \mathrm{~g}$ \\
$\mathrm{~Tb}_{4} \mathrm{O}_{7}=1337 \mathrm{~g}$ & $\mathrm{~Tb}=1137 \mathrm{~g}$ \\
$\mathrm{Yb}_{2} \mathrm{O}_{3}=1331 \mathrm{~g}$ & $\mathrm{Yb}=1169 \mathrm{~g}$
\end{tabular}



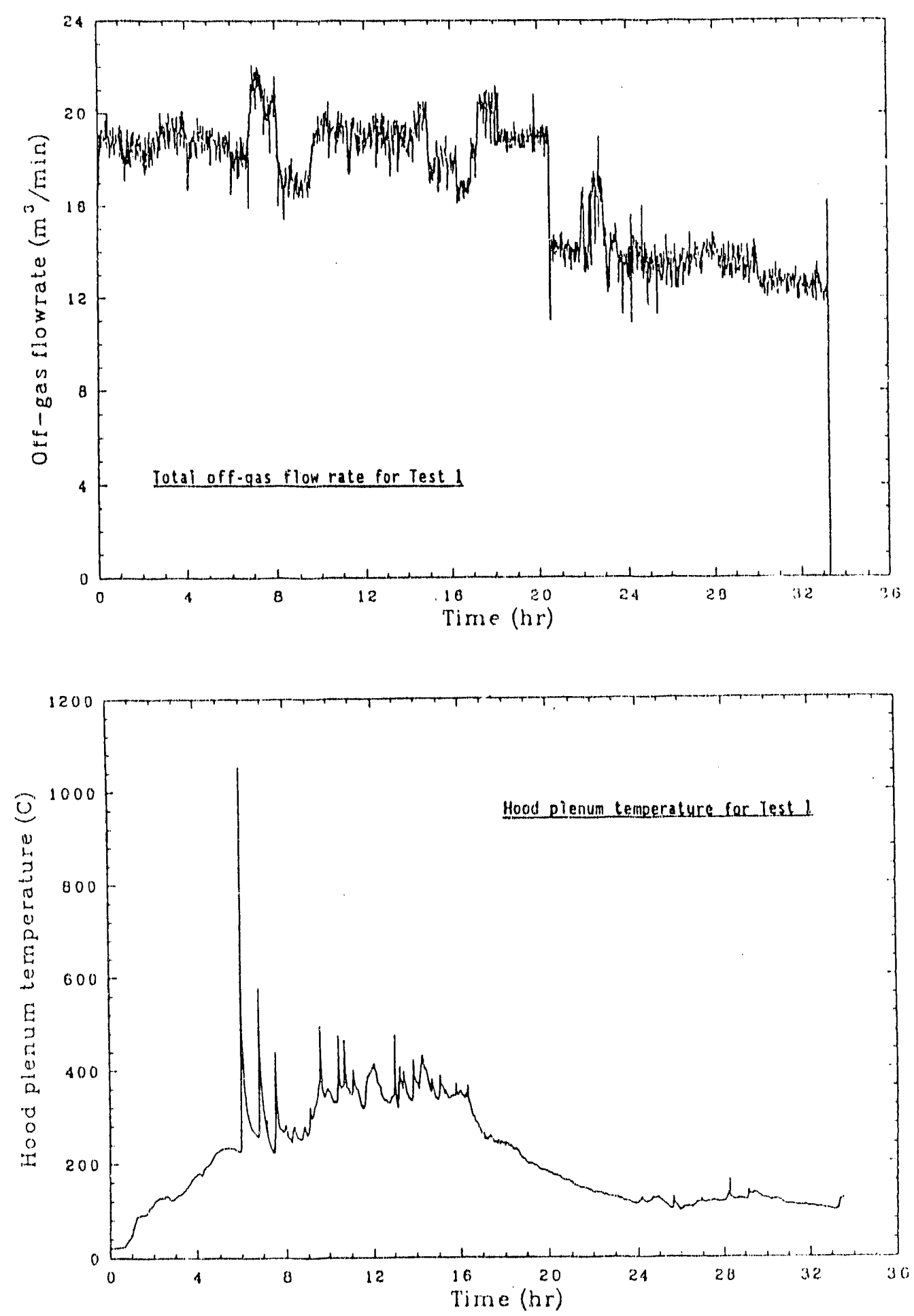

Figure 4. Measured off-gas flow rate and hood plenum temperature during the IFT-1 experiment. 

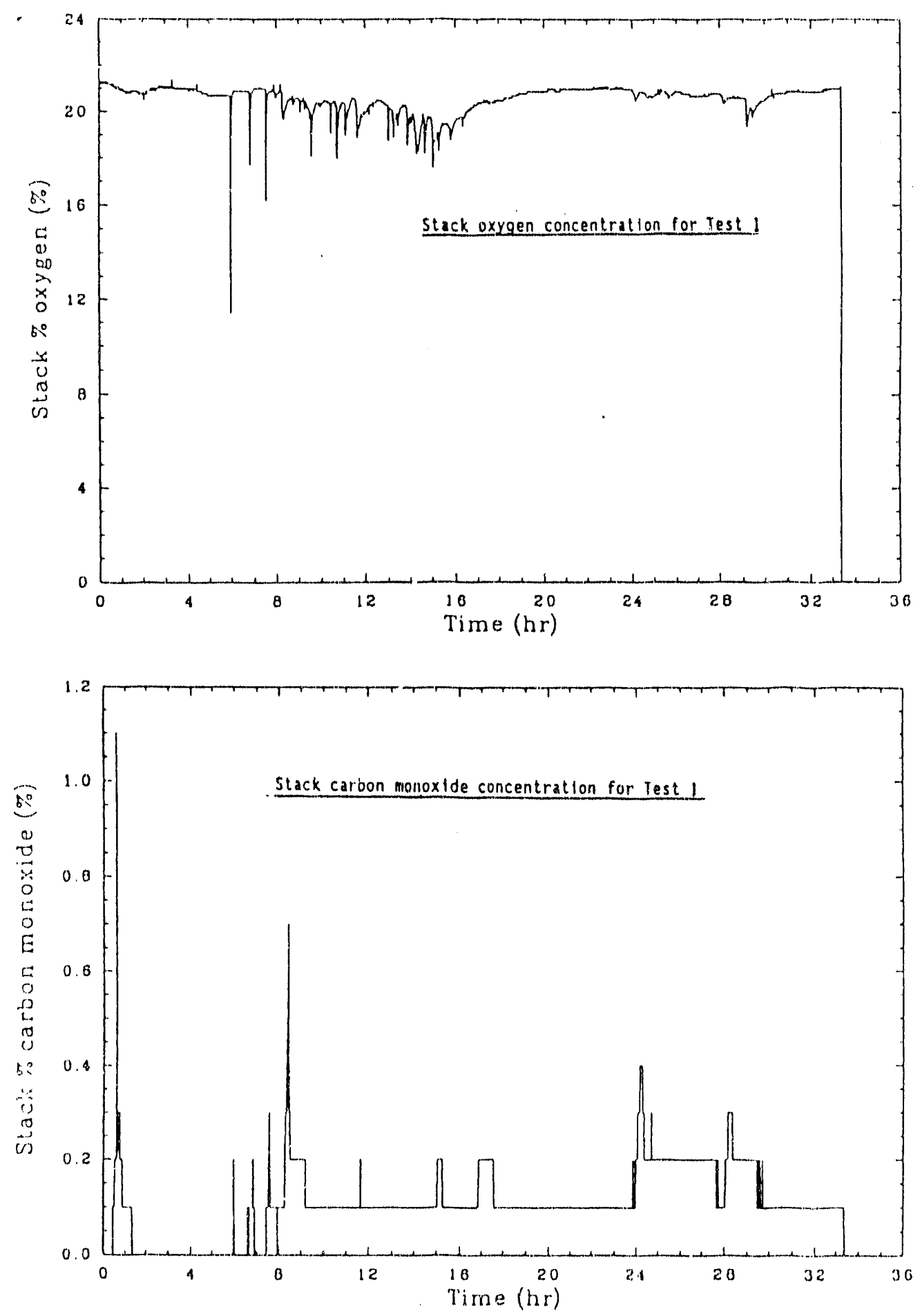

Figure 5. Measured oxygen $\left(\mathrm{O}_{2}\right)$ and $\mathrm{CO}$ hood concentrations during the IFT-1 experiment. 
After testing, the amounts of tracers were measured in retrieved samples of vitrificd soil, as well as at various locations within the collection hood, off-gas piping surfaces, scrub solution, and HEPA filters (collectively referred to as the off-gas collection system). Although quantitative determination of tracer amounts was hampered by sampling uncertainties, results indicate that the majority of the tracers were retained in the vitrified product. Nevertheless, several pereent of the tracer material was found within the off-gas collection system for test IFT-1 as follows:

\section{IFT-1 Tracer Release Data}

\begin{tabular}{|c|c|c|c|c|}
\hline Oxide Inventory & Rare Earth & $\begin{array}{l}\text { Hood/Duct } \\
\text { Deposits }\end{array}$ & $\begin{array}{l}\text { Scrub } \\
\text { Solution } \\
\end{array}$ & $\begin{array}{l}\text { Max. Release } \\
\text { Fraction }\end{array}$ \\
\hline $\mathrm{Dy}_{2} \mathrm{O}_{3}=13.36 \mathrm{~g}$ & Dy $=1164 \mathrm{~g}$ & $4.7-6.2 \mathrm{~g}$ & $7.5 \mathrm{~g}$ & 0.012 \\
\hline $\mathrm{Tb}_{4} \mathrm{O}_{7}=1337 \mathrm{~g}$ & $\mathrm{~Tb}=1137 \mathrm{~g}$ & $28-29.9 \mathrm{~g}$ & $14.0 \mathrm{~g}$ & 0.039 \\
\hline $\mathrm{Yb}_{2} \mathrm{O}_{3}=1331 \mathrm{~g}$ & $Y b=1169 \mathrm{~g}$ & $11-12.3 \mathrm{~g}$ & $17.5 \mathrm{~g}$ & 0.025 \\
\hline Total $=4004$ & $=3473 \mathrm{~g}$ & & & age $\overline{0.025}$ \\
\hline
\end{tabular}

These results form the basis for data comparisons used in this report.

\subsection{IFT-2 Test and Tracer Results}

Figure? indicates that the $\mathrm{Dy}_{2} \mathrm{O}_{3}$ tracer used in the IFT-2 experiment was placed only at one location, that is, in the middle of the stacked drum region at a buried depth of $\approx 5 \mathrm{ft}(60) \mathrm{in})$. Thus, release of tracer material would not be expected until ISV melting at this depth, as compared to the IFT-1 test conditions of tracer burial between 2 and 5 ft. The IFT-2 experiment was initiated at 1540 hours on July 11,1990 . Power to the electrodes was initially at $10 \mathrm{~kW}$ and gradually increased over the next 8 hours to $400 \mathrm{~kW}$. The test duration was 69.5 hours, with an achieved maximum melt depth of $3.9 \mathrm{~m}$ (129 in.) and an average melt rate of $1.8 \mathrm{in} . / \mathrm{h}$. As is noted in Figure 3 , a considerably slower melting rate is evident for IFT-2 versus IFT-1.

As discussed in Reference 4, there were three distinct IFT-2 test phases which can be correlated to exposure of buried waste samples to ISV melting:

- The instrumented can at the $0.6 \mathrm{~m}(2 \mathrm{ft}) \mathrm{depth}$

- The layer of stacked drums

- The layer of stacked boxes.

Analysis of pressure and thermocouple data indicate that destruction of the instrumented can was not coincident with hood pressurization, but rather that hood pressurization was caused by steam release. Further into the test, the stacked can region, which contained the $\mathrm{Dy}_{2} \mathrm{O}_{3}$ tracer material, was exposed to a slowdown in the melting rate and fewer hood pressure spikes. Onc consequence of the slow melting process was that most of the water in the sludge cans vaporized and escaped into the surrounding soil well ahead of the approaching melt front. These factors, combined with the additional $2 \mathrm{ft}$ of soil overburden, effectively prevented dynamic pressure spiking characteristic of IFT. 1 . 
The stacked box region was encountered at about 45 hours. During the time the melt front reached the stacked box region, hood temperature spiking was noted, which is considered the result of continued pyrolysis and combustion of the top layer of boxes (see Reference 4).

As in IFT-1, the vast majority of the dysprosium (Dy) tracer material was found to be associated with the ISV recrystallized soil. Hood/piping smear data, as well as results from HEPA filter analysis and scrub tank data, indicate that Dy was not released from the melt. Based on limited posttest soil sampling (similar as performed for IFT-1), it appears that there were no significant differences between tracer pretest soil concentrations and posttest concentrations derived from collected vitrified soil samples. On this basis, nil release of tracer material $\left(\mathrm{Dy}_{2} \mathrm{O}_{3}\right)$ was deduced for the IFT-2 experiment (see Reference 4).

\subsection{Summary of IFT Tracer Release Data}

Differences in test conditions relating to tracer release behavior should be noted. One difference concerns pit configuration, namely the additional $2 \mathrm{ft}$ of overburden in IFT-2 compared to IFT-1, as well as the stacked layered waste in IFT-2 versus the randomly-dump configuration employed in IFT-1. Likewise, a more rapid melting process was associated with IFT-1. Differences in pit configuration and melting rate could have influenced tracer release. Comparison between test results is complicated by the use of three different tracers in IFT-1, as compared to one tracer $\left(\mathrm{Dy}_{2} \mathrm{O}_{3}\right)$ in IFT-2. The one common tracer between the two tests, $\mathrm{Dy}_{2} \mathrm{O}_{3}$, was buried at different depths in the two tests. Likewise, the use of the posttest smear data from IFT-1 as pretest smear data for IFT-2 is suspect, since deposited material may have been lost during hood transport between the two test sites.

Accelerated melting combined with differences in burial depth may have promoted enhanced tracer release for IFT-1. Previous data from ISV tests at Pacific Northwest Laboratory (PNL) (see Reference 2) suggest that elements at greater depth are retained preferentially in the melt. This is consistent with the apparent reduced release of $\mathrm{Dy}_{2} \mathrm{O}_{3}$ tracer in IFT-2 compared to IFT-1. However, the data from IFT-1 alone do not support the hypothesis that elements at greater depth are preferentially retained in the melt. The use of different tracers in IFT-1 precludes definitive conclusions. There are too many differences between test conditions in the IFTs to allow definitive conclusions regarding the effect of depth and melting rate on tracer release.

Despite the above stated concerns, the tracer collection data indicate greater release for IFT-1 than IFT-2, which may relate to the clear differences in the degree of off-gassing noted for the two experiments. Figure 6 presents a comparison of measured hood temperatures and vacuum pressure for the two tests. The IFT-2 data show only 3 spiking events in hood vacuum pressure and a corresponding tempe ature increase, versus 14 spiking events for IFT-1. Although IFT-2 contained potentially more volatile waste then IFT-1, the vacuum pressure and temperature data suggest a more dynamic off-gassing process for IFT-1. An assessment of such off-gassing effects on tracer relcase potential is presentec in subsequent sections of this report. 

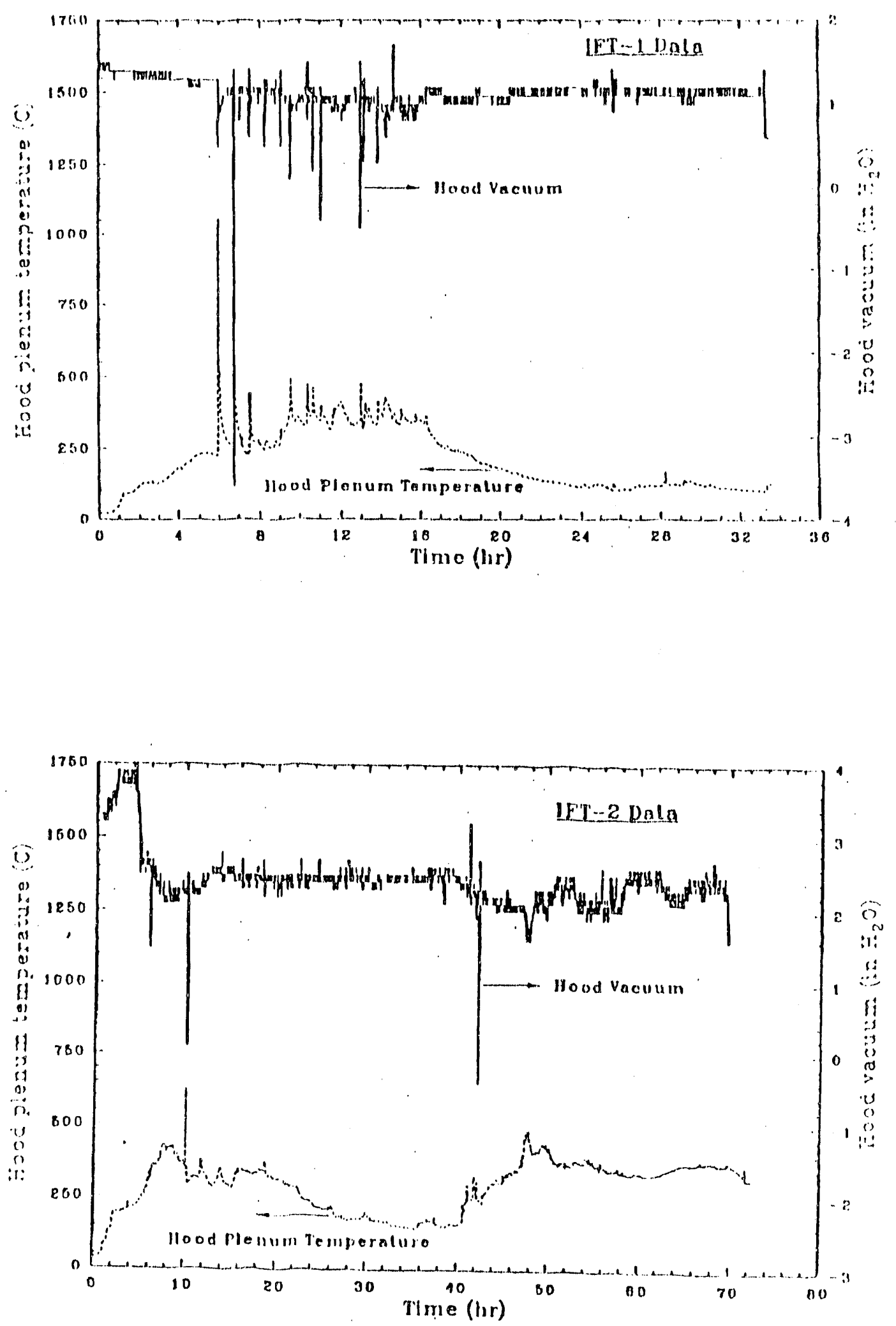

Figure 6. Comparison of off-gassing behavior noted in tests IFT-1 and IFT-2. 


\section{OVERVIEW OF MASS TRANSPORT DIJRING ISV MELTING}

An assessment of the ISV tracer release behavior can be app. vached from consideration of the fundamental equation for mass transport from a liquid pool:

$m_{\text {rel }}=k_{m} A\left(C_{\text {bulk }}-C_{\text {surface }}\right)$

where

$$
\begin{aligned}
& \mathrm{m}_{\mathrm{rel}}(\mathrm{g} / \mathrm{s})=\text { rate of mass released from free surface } \\
& \mathrm{k}_{\mathrm{m}}(\mathrm{cm} / \mathrm{s})=\text { overall mass transport coefficient } \\
& \mathrm{A}\left(\mathrm{cm}^{2}\right)=\text { surface area for release } \\
& C_{\text {bulk }}\left(\mathrm{g} / \mathrm{cm}^{3}\right)=\text { bulk concentration of species in the melt } \\
& \mathrm{C}_{\text {surface }}\left(\mathrm{g} / \mathrm{cm}^{3}\right)=\text { concentration at the melt surface. }
\end{aligned}
$$

The difficulty in application of Equation (1) lies in the specification of $k_{m}$, which is largely dictated by physical conditions. In this section, various models are examined for $\mathrm{k}_{\mathrm{m}}$, depending on governing physical conditions. Figure 7 illustrates the processes to be investigated.
a. A stagnant pool, where mass transport is controlled solely by species diflusion through the melt
b. A well-mixed pool, where mass transport is controlled by convective currents in the melt due to internal heating
c. Mas: transport due to carry-off by escaping gas bubbles.

To establish a basis to identify which mechanism would predominate for ISV melt environments, characteristic time constants $\left(t=k_{n} / R_{p}\right.$; where $R_{p}$ is the characteristic pool depth) are estimated and compared for each mechanism using characteristic IFT test conditions, the shortest time being indicative of the predominant release mechanism. Having established the dominant mass transport mode for IFT conditions, quantitative predictions of tracer release are then presented in Section 4 for the IFT-1 experiment.

\subsection{Diffusion Controlled Mass Transport}

As illustrated in Figure 7, if the melt is quiescent, random motion will still occur, leading to diffusion of solute molecules from regions of high concentration to low concentration. Thus, there exists an ever-present movement of solute species in the direction in which its concentration is lower, so that over time concentration equilibrium is established. This process is referred to as "diffusion" and its mathematical treatment is described by Fick's law. 
- = Tracer molecule

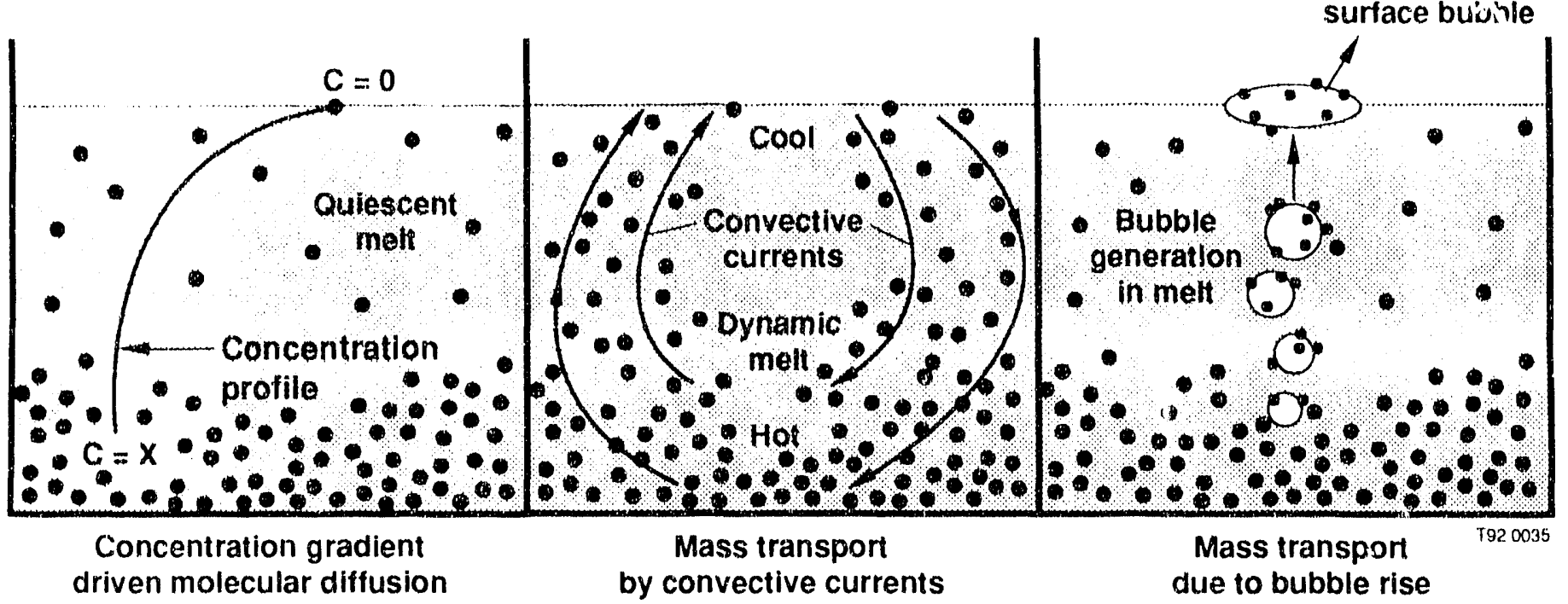

Figure 7. Illustration of potential mass transport modes for quiescent, dynamic, and gaseous melts.

For order-of-magnitude analysis, the ISV melt can be modeled as a hemispherical pool, where the mass transport coefficient $\left(k_{m}\right)$ and associated time constant $\left(t_{\text {dift }}\right)$ for diffusion can be approximated by the following expressions:

$\mathrm{k}_{\mathrm{m}}=\pi \mathrm{D} / \mathrm{R}_{\mathrm{p}}$

$\mathrm{t}_{\mathrm{difl}}=\mathrm{R}_{\mathrm{p}} / \mathrm{k}_{\mathrm{m}}$

where

$D=$ diffusion coefficient $\left(\mathrm{cm}^{2} / \mathrm{s}\right)$

$R_{p}=$ pool depth (cm).

\subsection{Convection Controlled Mass Transport}

Figure 7 also illustrates the condition where convection currents arise within the ISV melt pool due 10 internal heating. In such free convection systems, both heat and mass transfer are coupled phenomena. Analytic solutions for such coupled heat-mass transport systems are available only for idealized geometries and restrictions on density driven flow patterns. Thus, common practice is (n) make use of similarity analysis in conjunction with experimental data, to estimate the overall mass transfer coefficient $\left(\mathrm{k}_{\mathrm{m}}\right)$. For free convection, the following expression suggested in Reference 9 is employed:

$k_{m}=0.36\left(D / R_{p}\right) R a^{0.23}(\mathrm{Sc} / \mathrm{Pr})^{0.23}$

$t_{\text {comv }}=R_{p} / k_{m}$ 
where

$$
\begin{aligned}
& \mathrm{D}=\text { diffusion coefficient }\left(\mathrm{cm}^{2} / \mathrm{s}\right) \\
& \mathrm{R}_{\mathrm{p}}=\text { pool depth }(\mathrm{cm}) \\
& \mathrm{Ra}=\text { Rayleigh number }\left(\mathrm{g} \beta \mathrm{Q} R_{p}^{5} / \alpha \mathrm{k} \mu_{\mathrm{k}}\right) \\
& \mathrm{Sc}=\text { Schmidt number }\left(\mu_{\mathrm{k}} / \mathrm{D}\right) \\
& \mathrm{Pr}=\text { Prandtl number }\left(\mu_{\mathrm{k}} / \alpha\right) \\
& \mathrm{g}=\text { gravitational constant }\left(\mathrm{cm} / \mathrm{s}^{2}\right) \\
& \beta=\text { thermal expansion coefficient }\left(\mathrm{K}^{-1}\right) \\
& \mathrm{Q}=\text { volumetric heat source }\left(\mathrm{W} / \mathrm{cm}^{3}\right) \\
& \alpha=\text { thermal diffusivity }\left(\mathrm{cm}^{2} / \mathrm{s}\right) \\
& \mu_{\mathrm{k}}=\text { kinematic viscosity }\left(\mathrm{cm}^{2} / \mathrm{s}\right) \\
& \mathrm{k}=\text { thermal conductivity }(\mathrm{W} / \mathrm{cm}-\mathrm{K})
\end{aligned}
$$

\subsection{Mass Transfer Due to Bubble Rise}

Figure 7 illustrates the basic characteristics of tracer release due to bubble rise. For ISV melts which contain sufficient quantities of vaporous material, spherical bubbles will form and rise through the melt capturing tracer molecules in the process. The imbalance of pressure and surface tension forces at the melt surface leads to the formation of elliptical vapor domes, which become unstable with increased gas pressure releasing entrapped gas and tracers in the process.

To estimate the rate of bubble rise, the force balance illustrated in Figure 8 is cmployed; where a submerged spherical bubble, under the influence of buoyancy, will accelerate as it rises through the melt. Eventually the bubble will reach a constant terminal velocity $\left(V_{t}\right)$, where the forces of gravity $\left(F_{g}\right)$ and drag $\left(F_{d}\right)$ just balance the buoyancy force $\left(F_{t}\right)$, so that the following equilibrium force balance applies:

$(4 / 3) \pi\left(R_{b}^{3}\right) Q_{1} g=(4 / 3) \pi\left(R_{b}^{3}\right) Q_{g} g+6 \pi R_{b} \mu\left(V_{1}\right)$

where

$R_{b}=$ bubble radius 


$$
\begin{aligned}
& \mathbf{Q}_{\mathrm{l}}=\text { melt density } \\
& \mathbf{Q}_{\mathrm{g}}=\text { gas density } \\
& \mathbf{g}=\text { gravitation constant } \\
& \mathrm{H}=\text { melt viscosity. }
\end{aligned}
$$

Noting that $\mathbf{e}_{1}>>\mathbf{Q}_{g}$, the terminai risc velocity can be expressed as:

$V_{1}=2\left(R_{b}^{2}\right) e_{1} g / 9 \mu$

The limiting or maximum mass transport coefficient $\left(\mathrm{k}_{\mathrm{n}}\right)$ for tracer release due to bubble escape from the melt can be approximated as the terminal bubble relocity $\left(V_{t}\right)$, i.e.,:

$$
\mathrm{k}_{\mathrm{m}} \approx \mathrm{V}_{\mathrm{l}}=2\left(R_{b}^{2}\right) \mathrm{e}_{1} \mathrm{~g} / 9_{\mu}
$$

The associated time constant for bubble rise can thus be expressed as $t_{b r}=R_{p} / k_{m}$, where $R_{p}$ is again the pool depth. Inspection of Equation (8) indicates that the principal parameter to be specified is the buhble radius $\left(R_{b}\right)$, where a range of 1 to $5 \mathrm{~cm}$ is used for scoping predictions.

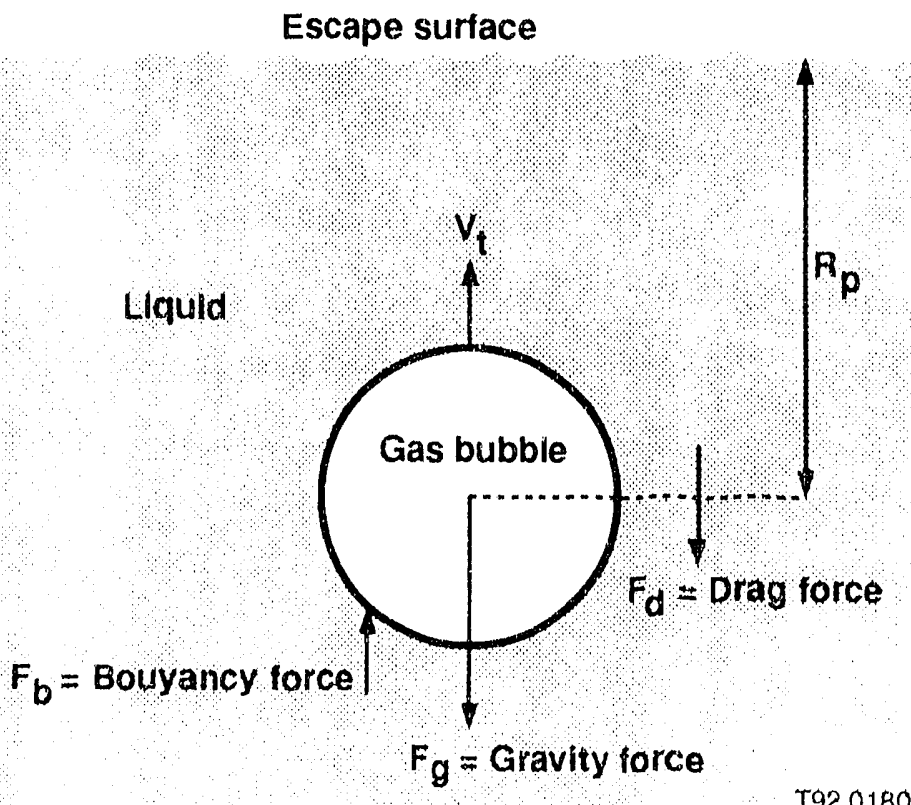

Figure 8. Simple force balance on a rising gas bubble in a viscous liquid. 


\subsection{Scoping Calculations}

Using property values presented in Table 2 (see also Appendix A), an assumed pool depth of $100 \mathrm{~cm}$, and a heating rate of $300 \mathrm{~kW}$ (typical of the IFT-1 heating rate, see Reference 1), characteristic release times are estimated in Tables 3-5. Although modeling approximations are apparent, nevertheless it is evident that bubble rise provides the most rapid means for tracer transport from basalt-based melts as follows:

$\begin{array}{ll}\text { Release Mechanism } & \text { Charactcristic Release Time } \\ \text { Diffusion } & \approx 73,700 \text { days } \\ \text { Free Convection } & \approx 790 \text { days } \\ \text { Bubble Rise } & <1 \text { minute }\end{array}$

With respect to species diffusion through molten soil, extremely long diffusion controlled release times are predicted in Table 3 , due to both the small diffusivity associated with molecular diflusion in liquids and the rather long distance for direct species migratic to be about $100 \mathrm{~cm}$ ). Although the calculations presented are simple order-of-magnitude estimates, nevertheless, diffusion times are clearly i juite slow.

The characteristic release time associated with convective currents within an iniernally heated pool (IFT-1 heating rate of $\approx 300 \mathrm{~kW}$ ) is estimated to be significantly smaller than that predicted for diffusion. Nevertheless, predicted values for free convection are on the order of $\approx 800$ days, which is significantly greater then typical ISV melt duration times of 1 to 2 days. Thus, free convection alone would not be responsible for large-scale release of oxide species, on the time frame of ISV process duration.

In contrast to both diffusion and convective controlled mass transport, the time scale associated with gas bubble rise through the melt is estimated in Table 5 to be on the order of a minute or less, depending on bubble size. The indication of this result is that carry-off of oxide species (either $\mathrm{Dy}_{2} \mathrm{O}$. $\mathrm{Th}_{4} \mathrm{O}_{7}, \mathrm{Yb}_{2} \mathrm{O}_{3}$, or $\mathrm{PuO}_{2}$ ) by escaping gas bubbles (duc to off-gassing of $\mathrm{CO}, \mathrm{CO}_{2}$, or water vapor) would be the dominant ISV release mechanism. Thus, more detailed investigation of this process is presented in the following section. 
Table 2. Summary of soil melt properties and system parameters.

\begin{tabular}{|c|c|}
\hline Property & Value \\
\hline Soll compesition (wi- $-\%$ ) & $62-\mathrm{SiO}_{2} / 12-\mathrm{Al}_{2} \mathrm{O}_{4} / 5-\mathrm{Fc}_{2} \mathrm{O}_{3} / 20$ - wher \\
\hline Mell lemperature $\left(\mathrm{T}_{\mathrm{mp}}\right)$ & $1447^{\circ} \mathrm{C}(1720 \mathrm{~K})$ \\
\hline Melt density $(\rho)$ & $2.2 \mathrm{~g} / \mathrm{cc}$ \\
\hline Melt viscosity $(\mu)$ & $300 \mathrm{~g} / \mathrm{s}-\mathrm{cm}(300) \mathrm{poisc})$ \\
\hline Melt kinematio viscosity $\left(\mu_{k}\right)$ & $\mu / \rho=136 \mathrm{~cm}^{2} / \mathrm{s}$ \\
\hline Melt thermal conductivity (k) & $0.0335 \mathrm{cal} / \mathrm{s} \cdot \mathrm{cm}-\mathrm{K}(14 \mathrm{~W} / \mathrm{m}-\mathrm{K})$ \\
\hline Melt specific heat $\left(C_{p}\right)$ & $0.26 \mathrm{cal} / \mathrm{g}-\mathrm{K}$ \\
\hline Mell thermal diffusivity $\left(\alpha=k / \rho C_{0}\right)$ & $0.0586 \mathrm{~cm}^{2} / \mathrm{s}$ \\
\hline Diflusion coefficient (D) & $0.5 \mathrm{E}-6 \mathrm{~cm}^{2} / \mathrm{s}$ (assumed, all species) \\
\hline \multicolumn{2}{|l|}{ Mell coefficient of thermal } \\
\hline Melt surlace tension $(o)$ & $10 \times 0) \mathrm{dy} / \mathrm{cm}$ (asiumed) \\
\hline \multicolumn{2}{|l|}{ System Paramelers } \\
\hline$=$ pool depth & $=100 \mathrm{~cm}$ (assumed) \\
\hline$V_{p}=$ pool volume $\left(2 \frac{\pi}{3} R_{p}^{3}\right)$ & $=2.09 \mathrm{E}+6 \mathrm{~cm}^{3}$ \\
\hline $\begin{array}{l}Q_{c}=\text { power supply } 10 \text { ISV pond } \\
Q \quad=\text { pool volumetric heating rate }\end{array}$ & $\begin{array}{l}=71,7(0) \mathrm{cal} / \mathrm{s}(300 \mathrm{~kW}) \\
=Q_{\mathrm{c}} N_{p}=0.034 \mathrm{cal} / \mathrm{cm}^{3}-\mathrm{s}\end{array}$ \\
\hline
\end{tabular}

Table 3. Estimation of time constant for diffusion-governed release.

$$
\begin{aligned}
& k_{\mathrm{m}}=\pi \mathrm{D} / \mathrm{R}_{\mathrm{p}}=\pi\left[0.5 \times 10^{\circ} \mathrm{cm}^{2} / \mathrm{s}\right] /(160 \mathrm{~cm})=1.57 \mathrm{E}-8 \mathrm{~cm} / \mathrm{s} \\
& \mathrm{L}_{\text {dufl }}=R_{\mathrm{p}} / k_{\mathrm{m}}=0.37 \mathrm{E}+9 \mathrm{~s}=73.6281 \text { days }
\end{aligned}
$$


Table 4. Estimation of tims constant for free convection.

$$
\begin{array}{rlrl}
\mathrm{k}_{\mathrm{m}} & =0.36\left(\mathrm{D} / \mathrm{R}_{\mathrm{p}}\right) \mathrm{Ra}^{0.23}(\mathrm{Sc} / \mathrm{Pr})^{0.23} \\
\mathrm{t}_{\mathrm{conv}} & =\mathrm{R}_{\mathrm{p}} / \mathrm{k}_{\mathrm{m}} & \\
\mathrm{g} & =980 \mathrm{~cm} / \mathrm{s}^{2} & \beta=3.1 \mathrm{E}-5 \mathrm{~cm} / \mathrm{cm}-\mathrm{K} \\
\mathrm{Q} & =0.034 \mathrm{cal} / \mathrm{cm}^{3}-\mathrm{s} & \alpha=0.0586 \mathrm{~cm} / \mathrm{s} \\
\mu_{\mathrm{k}} & =136 \mathrm{~cm}^{2} / \mathrm{s} & \mathrm{k}=0.0335 \mathrm{cal} / \mathrm{s}-\mathrm{cm}-\mathrm{K} \\
\mathrm{D} & =0.5 \mathrm{E}-6 \mathrm{~cm}^{2} / \mathrm{s} &
\end{array}
$$

$$
\begin{aligned}
\mathrm{AA} & =\mathrm{g} \beta \mathrm{QR} R^{5}=(980)(3.1 \mathrm{E}-5)(0.0335)\left(100^{5}\right)=1.02 \mathrm{E}+7 \mathrm{cal}-\mathrm{cm}^{3} / \mathrm{K}-\mathrm{s}^{3} \\
\mathrm{BB} & =\alpha \mu_{\mathrm{k}} \mathrm{k}=(0.0586)(136)(0.0335)=0.267 \mathrm{cal}-\mathrm{cm}^{3} / \mathrm{K}-\mathrm{s}^{3} \\
\mathrm{Ra} & =\left(\mathrm{g} \beta \mathrm{QR} / \alpha \mu_{\mathrm{k}} \mathrm{k}\right)=\mathrm{AA} / \mathrm{BB}=3.82 \mathrm{E}+7 \\
\mathrm{Sc} & =\mu_{\mathrm{k}} / \mathrm{D}=2.73 \mathrm{E}+8 \quad \operatorname{Pr}=\mu_{\mathrm{k}} / \alpha=2.32 \mathrm{E}+3 \quad \mathrm{Sc} / \mathrm{Pr}=11.77 \mathrm{E}+4 \\
\mathrm{k}_{\mathrm{m}} & =0.36\left(\mathrm{D} / \mathrm{R}_{\mathrm{p}}\right) \mathrm{Ra}^{0.23}(\mathrm{Sc} / \mathrm{Pr})^{0.23} \\
& =0.36(0.5 \mathrm{E}-6 / 100)(55.4)(14.66)=1.47 \mathrm{E}-6 \mathrm{~cm} / \mathrm{s} \\
\mathrm{t}_{\mathrm{r}, \mathrm{conv}} & =\mathrm{R} / \mathrm{k}_{\mathrm{m}} \approx 6.8 \mathrm{E}+7 \text { seconds } \approx 790 \text { days }
\end{aligned}
$$

Table 5. Estimation of time constant for bubble rise.

$$
\begin{array}{ll}
\mathrm{k}_{\mathrm{m}} \approx \mathrm{V}_{\mathrm{l}}=2\left(R_{b}^{2}\right) \mathrm{e}_{\mathrm{L}} \mathrm{g} / 9 \mu & \mathrm{t}_{\mathrm{br}}=\mathrm{R}_{\mathrm{p}} / \mathrm{k}_{\mathrm{m}} \\
\mathrm{R}_{\mathrm{p}}=\text { pool depth }=100 \mathrm{~cm} & \mathrm{R}_{\mathrm{b}}=\text { bubble radius }=1 \text { and } 5 \mathrm{~cm} \\
\mathrm{Q}_{\mathrm{l}}=\text { melt density }=2.2 \mathrm{~g} / \mathrm{cm}^{3} & \mu=\text { melt viscosity }=300 \mathrm{~g} / \mathrm{cm} \mathrm{s} \\
\mathrm{g}=\text { gravity constant }=980 \mathrm{~cm} / \mathrm{s}_{2} & \\
\underline{\mathrm{R}}_{\mathrm{h}}=1 \mathrm{~cm} & \\
\mathrm{k}_{\mathrm{ln}} \approx \mathrm{V}_{\mathrm{l}}=2\left(R_{b}^{2}\right) \mathrm{e}_{\mathrm{l}} \mathrm{g} / 9 \mu=2(1)^{2}(2.2)(980) /[9 \times 300]=1.597 \mathrm{~cm} / \mathrm{s} \\
\mathrm{t}_{\mathrm{br}}=\mathrm{R}_{\mathrm{p}} / \mathrm{k}_{\mathrm{m}} \approx 6.3 \mathrm{~seconds} \\
\underline{\mathrm{R}}_{\mathrm{l}}=5 \mathrm{~cm} \\
\mathrm{k}_{\mathrm{m}} \approx \mathrm{V}_{\mathrm{l}}=2\left(R_{b}^{2}\right) \mathrm{e}_{\mathrm{l}} \mathrm{g} / 9 \mu=2(5)^{2}(2.2)(980) /[9 \times 300)=39.9 \mathrm{~cm} / \mathrm{s} \\
\mathrm{l}_{\mathrm{br}}=\mathrm{R}_{\mathrm{p}} / \mathrm{k}_{\mathrm{m}} \approx 2.5 \mathrm{~seconds}
\end{array}
$$




\section{PREDICTIONS OF ISV TRACER RELEASE DUE TO BUBBLE RISE}

Of the three transport modes examined in the previous section (i.e.,diffusion through a stagnant pool, mass transport by convective currents, and carry-oll by escaping gas bubbles), clearly bubble escape provides the dominant release mode for ISV melts; thus, a more detailed investigation of this process is presented here. Phenomena investigated include characterization of bubble size requirements for release, bubble growth and coalesence behavior, and an evaluation of empiricallyhased mass transport correlations for bubble release from liquids. Once governing parameters have been established, predictions are made of tracer release for conditions associated with the ISV IFT-1 experiment and results compared with test findings.

\subsection{Minimum Bubble Size}

As depicted in Figure 9, release of gas bubbles from the ISV melt is assumed to be controlled by completion between buoyancy driven bubble rise versus convective currents that tend to continuously entrain the bubble within the melt. Under such assumptions bubble release will occur only if the buoyant velocity is large enough to overcome the convective currents. Comparison of the bubble rise velocity with the convective velocity thus determines the minimum bubble size that can escape the melt.

As noted in Section 3, the terminal rise veloci.y $\left(V_{1, \text { rise }}\right)$ of a spherical bubble can be approximated from the force balance between drag and, fravity versus the upward buoyancy, yiclding the following expression:

$V_{t, \text { rise }}=\left[\frac{2 \rho g R_{b}^{2}}{9 \mu}\right]$

where

$$
\begin{aligned}
& \rho \quad=\text { melt density }\left(\mathrm{g} / \mathrm{cm}^{3}\right) \\
& \mathrm{g} \quad=\text { acceleration due } \mathrm{t} \text { ) gravity }\left(\mathrm{cm} / \mathrm{s}^{2}\right) \\
& \mathrm{R}_{\mathrm{h}} \quad=\text { bubble radius }(\mathrm{cm}) \\
& \mu \quad=\text { melt viscosity }(\mathrm{g} / \mathrm{s}-\mathrm{cm}) .
\end{aligned}
$$




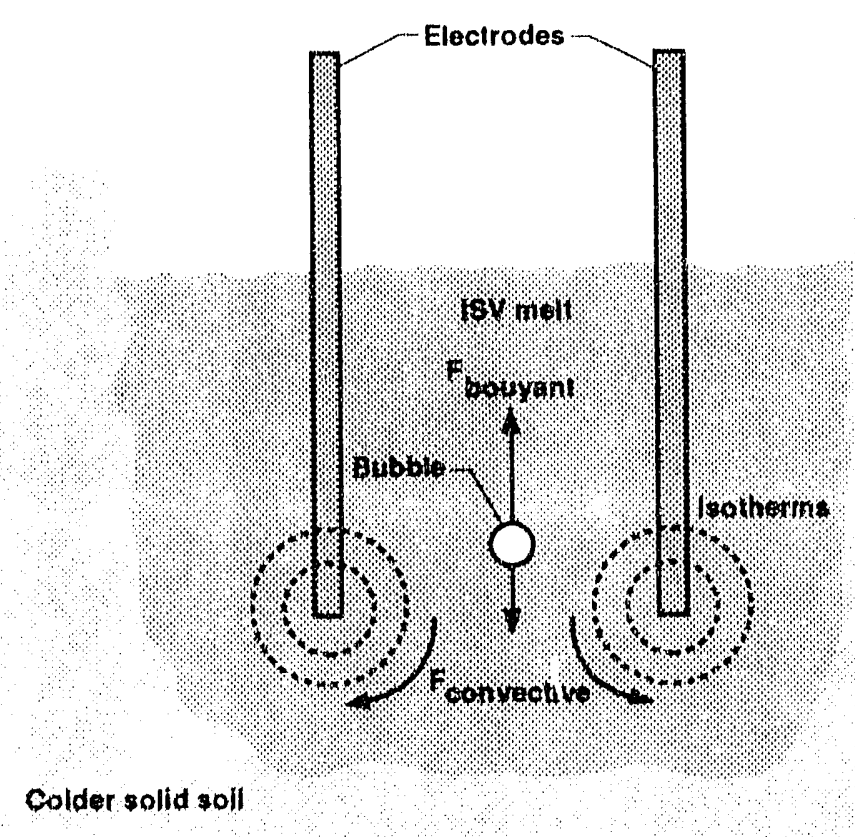

1920184

Figure 9. Illustration of buoyant rise versus circular convective currents for bubble entrainment.

The convective velocity can be obtained from an energy balance and is given by (see Reference 9):

$V_{\text {conv }}=\left\lfloor\frac{2 Q}{\rho A C_{p} \Delta T}\right]$

where

$Q=$ heating rate of pool (calls)

$A=$ cross-sectional area of pool $\left(\mathrm{cm}^{2}\right)$

$\mathrm{C}_{\mathrm{p}}=$ heat capacity $(\mathrm{cal} / \mathrm{g}-\mathrm{K})$

$\Delta \mathrm{T}=$ temperature difference from pool center to surface $(\mathrm{K})$.

It should be recognized that the temperature difference $(\Delta T)$ and, thus, local convective velocities may vary with pool depth. Nevertheless, the above expression can be used for order-of- 
magnitude estimates of free convective currents within the melt, where the minimum bubble radius $\left(R_{b, \text { min }}\right)$ for escape can be obtained from the inequality that $V_{t, \text { rise }}>V_{\text {conv }}$ :

$R_{b, \text { min }}=\left[\frac{9 Q \mu}{\rho^{2} A C_{p} g \Delta T}\right]^{1 / 2}$

Calculational results for Equation (11) are presented in Table 6 at typical ISV heating rates of $3(0) \mathrm{KW}$ and soil melt properties. As indicated for temperature differentials $(\Delta \mathrm{T}$, in the range of $50-3.30 \mathrm{~K}$ and soil melt viscosities $(\mu)$ of $300-500 \mathrm{~g} / \mathrm{cm}-\mathrm{s}(300-500$ poise), minimum bubble radii on the order of $\approx(0.24-0.08 \mathrm{~cm}$ are predicted. These radii are representative of a minimum bubble size for escape, where convective currents are assumed to entrain smaller bubbles within the melt.

\subsection{Maximum Bubble Size}

Regardless of the initial bubble size, growth will occur due to a decrease in hydrostatic head as the bubble rises through the melt. However the bubble cannot grow to be arbitrarily large, since surface instabilities at the leading edge eventually cause it to become unstable and shatter. A frequently cited criterion for bubble breakup is that deduced by Levich. ${ }^{10}$ This criterion is based on the assumption that once the dynamic pressure created by circulation of gases within the bubble exceed its surface tension, the bubble becomes unstable yielding the following expression for the maximum bubble size: ${ }^{10}$

$$
R_{t, \text { max }}=\frac{0.9(\sigma)}{V_{t, \text { the }}^{2}\left(\rho_{8} \rho_{1}^{2}\right)^{1 / 3}}
$$

where $V_{1, \text { rise }}$ is the terminal rise velocity [see Equation (9)] and $\rho_{\mathrm{g}}$ and $\rho_{\mathrm{l}}$ are the density of the gas and liquid (melt), respectively. Substitution of Equation (9) into Equation (12), yields the following Sth-order expression for the maximum bubble radius:

$$
R_{h, \text { max }}^{5}=\frac{(18.2)\left(\sigma \mu^{2}\right)}{g^{2} \rho_{1}^{2}\left(\rho_{g} \rho_{1}^{2}\right)^{1 / 3}}
$$

Table 7 presents calculational predictions using the Levich criterion (sec Reference 10) and suggests maximum bubbles radii of aboul $6 \mathrm{~cm}$. For water properties, Equation (13) yiclds maximum bubble radii of about $1.8-2.0 \mathrm{~cm}$ (see References 10 and 11 ), which partially alltributable to a lower surfice tension $(\approx 70 \mathrm{dy} / \mathrm{cm})$ compared to that of molten soil $(\approx 1000) \mathrm{dy} / \mathrm{cm})$. For present purposes only, bubbles sufficiently far removed from the effects of hydrodynamic instabilities and wave breakup will be considered stable bubble carriers for tracer release, that is, a maximum bubble radius $\left(R_{b, \text { mix }}\right)$ of about $2 \mathrm{~cm}$. 
Table 6. Estimation of minimum bubble size for escape from ISV melts.

\section{Governing Equation}

Parameter Values

$\rho \quad=$ melt density $=2.2 \mathrm{~g} / \mathrm{cm}^{3}$

$\mathrm{C}_{\mathrm{p}}=$ melt sp.cific heat $=0.26 \mathrm{cal} / \mathrm{g} \cdot \mathrm{K}$

$\mathrm{Q}=$ pool he ating rate $(300 \mathrm{KW})=7.17 \mathrm{E}+4 \mathrm{cal} / \mathrm{s}$

$A=$ ISV-IFT cross-sectional pool area $\approx 10 \mathrm{ft} \times 10 \mathrm{ft} \approx 9.3 \mathrm{E}+4 \mathrm{~cm}^{2}$

$\mathrm{g} \quad=$ gravity constant $=980 \mathrm{~cm} / \mathrm{s}^{2}$

$\Delta \mathrm{T}=$ pool lemperature difference $=50,100,300 \mathrm{~K}$

$\mu=$ melt viscosity $=300,500 \mathrm{~g} / \mathrm{cm}-\mathrm{s}$

Calculation

$\mathrm{B}^{\prime}=\left[9 \mathrm{Q} / \rho^{2} \mathrm{AC} \mathrm{p}\right]=5.626 \mathrm{E}-3 \mathrm{~K}-\mathrm{s}-\mathrm{cm}^{3} / \mathrm{g}$

$\begin{array}{llll}\Delta \mathrm{T}_{1} \mathrm{~K} & \frac{\mu, \mathrm{g} / \mathrm{cm}-\mathrm{s}}{50} & \frac{\mathrm{B}^{\prime} \mu / \Delta \mathrm{T}, \mathrm{cm}^{2}}{0.03376} & \underline{\mathrm{R}}_{\mathrm{b}, \min 2} \mathrm{~cm} \\ & 300 & 0.0563 & 0.184 \\ & 500 & & 0.237 \\ 100 & 300 & 0.0169 & 0.130 \\ & 500 & 0.0281 & 0.168 \\ 300 & 300 & & \\ & 500 & 5.626 \mathrm{E}-3 & 0.075 \\ & & 9.377 \mathrm{E}-3 & 0.097\end{array}$


Table 7. Estimation of maximum bubble size for ISV melts.

\section{Governing Equation}

$R_{l, \text { max }}^{5}=\frac{(18.2)\left(\sigma \mu^{2}\right)}{g^{2} \rho_{1}^{2}\left(\rho_{g} \rho_{l}^{2}\right)^{1 / 3}}$

\section{Parameter Values}

$\rho_{1}=$ melt density $=2.2 \mathrm{~g} / \mathrm{cm}^{3}$

$\mathrm{sg}=$ specilic gravity $=2.2$

$\mathrm{g} \quad=$ gravity constant $=980 \mathrm{~cm} / \mathrm{s}^{2}$

$\sigma \quad=$ suriace tension (assumed) $=1000 \mathrm{dy} / \mathrm{cm}\left(\mathrm{g} / \mathrm{s}^{2}\right)$

$\mu=$ melt viscosity $=300,500 \mathrm{~g} / \mathrm{cm}-\mathrm{s}$

$\mathrm{T}_{\mathrm{m}}=$ melt temperature $=1720 \mathrm{~K}(2636 \mathrm{~F})$

\section{Calculation of Gas Density}

$\rho_{\mathrm{g}} \quad=$ density of gas (water vapor at $1720 \mathrm{~K}, \mathrm{P}_{\mathrm{h}}$ )

$\mathrm{X}=$ pool height (assumed) $=4 \mathrm{ft}=122 \mathrm{~cm}$

$\mathrm{P}_{\mathrm{h}}=$ pressure head $=14.7 \mathrm{psi}+\left[\mathrm{X}(\mathrm{sg})\left(62.4 \mathrm{lb} / \mathrm{ft}^{3}\right) / 144=3.8 \mathrm{psi}\right)$

$=18.5 \mathrm{psi}$

$\rho_{\mathrm{g}} \quad=$ density of water vapor (at $\left.1720 \mathrm{~K}, 18.5 \mathrm{psi}\right)=1.52 \mathrm{E}-4 \mathrm{~g} / \mathrm{cm}^{3}$

Calculation

$$
\begin{aligned}
& A=18.2\left(10(0) \mathrm{g} / \mathrm{s}^{2}\right)=10.2 \mathrm{E}+3 \mathrm{~g} / \mathrm{s}^{2} \\
& B=\left(980 \mathrm{~cm} / \mathrm{s}^{2}\right)^{2}\left(2.2 \mathrm{~g} / \mathrm{cm}^{3}\right)^{2}=4.65 \mathrm{E}+6 \mathrm{~g}^{2} / \mathrm{s}^{4}-\mathrm{cm}^{4} \\
& C=\left|\left(1.52 \mathrm{E}-4 \mathrm{~g} / \mathrm{cm}^{3}\right)\left(2.2 \mathrm{~g} / \mathrm{cm}^{3}\right)^{2}\right|^{1 / 3}=0.0907 \mathrm{~g} / \mathrm{cm}^{3} \\
& D=A /[B C]=0.0434 \mathrm{~cm}^{7}-\mathrm{s}^{2} / \mathrm{g}^{2} \\
& R_{b, \text { mix }}=\left(0.0434 \mu^{2}\right)^{0.2}
\end{aligned}
$$

$\begin{array}{cc}\text { ․ } \mathrm{g} / \mathrm{cm}-2 & \underline{\mathrm{R}}_{\mathrm{b}, \max L \mathrm{~cm}} \\ 3(\mathrm{k}) & 5.2 \\ 5(0) & 6.4\end{array}$




\subsection{Bubble Coalescence}

From the preceding estimates of bubble size $\left(\mathrm{R}_{b} \approx 0.2-2.0 \mathrm{~cm}\right)$ it is clear that considerable coalescence must accompany bubble rise through the melt. To estimate the extent of such changes in bubble morphology due to coalescence, the bubble equation-of-state must be specilied; that is, one must be able to estimate the number of gas atoms contained in a bubbie as a function of its size. Here the correlation recommended by Olander ${ }^{12}$ is employed as follows:

$N_{g b}=\frac{V_{b}}{\left[A+B R_{b}\right]}$

where

$$
\begin{aligned}
& N_{\mathrm{gb}}=\text { number of gas atoms per bubble of radius } \mathrm{R}_{\mathrm{b}} \\
& \mathrm{V}_{\mathrm{b}}=\text { Bubble volume }=4 \pi R_{b}^{3} / 3 \\
& \mathrm{R}_{\mathrm{b}}=\text { bubble radius } \\
& \mathrm{A}=85 \mathrm{E}-24 \mathrm{~cm}^{3} \\
& \mathrm{~B}=\mathrm{kT} / 2 \mathrm{o} \\
& \mathrm{k}=\text { Boltzmann Constant }=1.38 \mathrm{E}-16 \mathrm{dy}-\mathrm{cm} / \mathrm{K} \\
& \mathrm{T}=\text { melt temperature } \\
& \sigma \quad=\text { melt surface tension. }
\end{aligned}
$$

Table 8 presents calculational results, where the number of gas atoms is estimated $\left(\mathrm{N}_{\mathrm{gb}}\right)$ for bubbles of a particular size. Bubble radii at nucleated conditions $\left.\left(R_{b} \approx 10-10\right) A^{\circ}\right)$ and for bubbles large enough to escape from the ISV convective pool are assessed for their number of gas atoms. The salient feature to note is that to go from nucleated radii on the order of $R_{b} \approx 10-100 A^{\circ}$ $\left(10^{-7}-10^{-6} \mathrm{~cm}\right)$ to macrobubbles of radii $R_{b} \approx 1.0-2.0 \mathrm{~cm}$, requires extensive coalescence of numerous microbubbles into fewer but much larger macrobubbles. Thus, for microbubbles to grow to a size that is sufficiently large to allow buoyancy induced escape from the melt, requires large-scale sweeping of gas atoms into the rising bubble, which is also indicative of sweeping of solute tracer species as well.

Since detailed estimates of the collision frequency, resultant transient nature of bubble growth, and sweeping of solute tracer species by gas migration requires complex numerical computation, common practice (for order-of-magnitude estimates) is to make use of empirical relations developed for mass transport due to bubble rise; the approach that is used here. 
Table 8. Estimated bubble morphology characteristics due to coalescence.

\section{Fission Gas Bubble Equation-of State}

$$
\begin{aligned}
& \mathrm{N}_{\mathrm{gb}}=\text { number of gas atoms per bubble of radius } \mathrm{R} \\
& =\frac{\mathrm{V}_{\mathrm{b}}}{\left[\mathrm{A}+\mathrm{BR}_{\mathrm{b}}\right]} \\
& V_{b}=\text { bubble volume }=4 \pi R_{b}^{3} / 3 \quad A=85 \mathrm{E}-24 \mathrm{~cm}^{3} \\
& \mathrm{R}_{\mathrm{b}}=\text { bubble radius } \quad \mathrm{B}=\mathrm{kT} / 2 \mathrm{o} \\
& \mathrm{k}=\text { Boltzmann Constant }=1.38 \mathrm{E}-16 \mathrm{dy}-\mathrm{cm} / \mathrm{K} \\
& \mathrm{T}=\text { melt temperature }=1720 \mathrm{~K} \\
& \sigma \quad=\text { melt surface tension (assumed) }=1000) \mathrm{dy} / \mathrm{cm}
\end{aligned}
$$

\begin{tabular}{|c|c|c|c|}
\hline$\underline{\mathrm{R}}_{\mathrm{n}, 2} \mathrm{~cm}$ & $\underline{V}_{10} \mathrm{~cm}^{3}$ & {$[A+B R], \mathrm{cm}^{3}$} & $\underline{N}_{g b}$ atoms/bubbles \\
\hline \multicolumn{4}{|c|}{ Nuclcated bubble radii } \\
\hline $1.0 \mathrm{E}-7$ & $4.19 \mathrm{E}-21$ & 9.7 E-23 & 43 \\
\hline $1.0 \mathrm{E}-6$ & $4.19 \mathrm{E}-18$ & $2.05 \mathrm{E}-22$ & 20,440 \\
\hline
\end{tabular}

Calculation

Bubble radii after coalescence

\begin{tabular}{llll}
0.01 & $4.19 \mathrm{E}-6$ & $1.2 \mathrm{E}-18$ & $3.49 \mathrm{E}+12$ \\
0.10 & $4.19 \mathrm{E}-3$ & $1.2 \mathrm{E}-17$ & $3.49 \mathrm{E}+14$ \\
$1 .(0)$ & 4.19 & $1.2 \mathrm{E}-16$ & $3.49 \mathrm{E}+16$ \\
$2 .(0)$ & 33.5 & $2.4 \mathrm{E}-16$ & $1.40 \mathrm{E}+17$ \\
\hline
\end{tabular}

\subsection{Mass Transport Coefficient for Bubble Rise}

Although random-walk type numerical models can be employed to assess delailed gas and solute (tracer) migration and collision characteristics as bubbles form, grow, and rise through the melt, common practice is to use empirical relations developed for mass transport due to bubble rise-the method employed here. Such an approach generally involves the use of empirical expressions for the Sherwood number (Sh), specifically developed for bubbles rising in a liquid. Knowing the Sherwood number (Sh) and the molecular diffusivity (D) of the various solute species in the melt, the overall mass transport coefficient $\left(\mathrm{k}_{\mathrm{m}}\right)$ can then be obtained:

$k_{\mathrm{m}}=\operatorname{Sh}(\mathrm{D}) / \mathrm{d}_{\mathrm{b}}$

where $d_{h}$ is the characteristic bubble diameter. Such factors as bubble shape, flow regime, and density of bubbles (swarms), all influence overall mass transport and, thus, must be factored into such expressions for the Sherwood number.

From the preceding discussion, it is obvious large-scale coalescence precedes bubble rise, resulting in the sweeping of numerous smaller bubbles into fewer but much larger bubbles that contain the vast majority of escaping gas or vapor atoms. Likewise, convective currents will tend to 
re-entrain the smaller bubbles within the melt, so no net mass release from the mell can occur by these small bubbles. Thus, overall release characteristics can be considered governed by the larger isolated bubbles that have the potential to escape from the melt. For isolated bubbles, the following generalized expressions for Sherwood number (Sh) have been suggested in the literature (see References 11 and 13):

$\mathrm{Sh}=1.13\left(\mathrm{Pe}^{1 / 2}\right)\left[\frac{\mathrm{d}_{\mathrm{b}}}{0.45+0.2 \mathrm{~d}_{\mathrm{b}}}\right]$

$\mathrm{Sh}=0.65 \mathrm{Pe}^{1 / 2} \quad$ for $\mathrm{Re}<10$

$\mathrm{Sh}=1.13\left[1-\frac{2.96}{\mathrm{Re}^{1 / 2}}\right]^{1 / 2} \mathrm{Pe}^{1 / 2} \quad 100 \leq \operatorname{Re} \leq 400$

where

$$
\begin{aligned}
& \text { Re }=\text { Reynolds Number }=V_{b}\left(\rho_{1}\right) d_{b} / \mu \\
& P c=\text { Peclet Number }=V_{b} d_{t} / D \\
& S h=\text { Sherwood Number }=k_{m} d_{b} / D \\
& D=\text { Diffusion coefficient }\left(\mathrm{cm}^{2} / \mathrm{s}\right) \\
& V_{b}=\text { Bubble rise velocity }(\mathrm{cm} / \mathrm{s}) \\
& d_{b}=\text { Bubble diarneter }(\mathrm{cm}) \\
& \rho_{1}=\text { Liquid or melt density }\left(\mathrm{g} / \mathrm{cm}^{3}\right) \\
& \mu=\text { Melt viscosity }(\mathrm{g} / \mathrm{s}-\mathrm{cm}) .
\end{aligned}
$$

Solving for the Sherwood Number (Sh) gives the overall mass transport coefficient $\left(k_{m}\right)$, which when combined with the following equation, yields the rate of mass transfer of a solute species due to bubble rise through the melt:

$m_{r e l}=k_{r n} A\left(C_{\text {bulk }}-C_{\text {surface }}\right)$,

where

$\mathrm{m}_{\mathrm{rel}} \quad=$ rate of mass released from free surface $(\mathrm{g} / \mathrm{s})$ 


$$
\begin{array}{ll}
k_{\mathrm{m}} & =\text { overall mass transport cocflicient }(\mathrm{cm} / \mathrm{s}) \\
\mathrm{A} & =\text { surface area for release }\left(\mathrm{cm}^{2}\right) \\
\mathrm{C}_{\text {pulk }} & =\text { bulk concentration of solute species in the melt }\left(\mathrm{g} / \mathrm{cm}^{3}\right) \\
\mathrm{C}_{\text {surface }} & =\text { concentration of solute species at the melt surface }\left(\mathrm{g} / \mathrm{cm}^{3}\right) \text {. }
\end{array}
$$

Knowing the bubble size $\left(\mathrm{R}_{\mathrm{b}}\right)$ and making use of the appropriate expression for the Sherwood number (Sh), overall mass transport/release behavior can be determined, where calculational estimates for the ISV IFT-1 test conditions are presented in the following section.

\subsection{Best Estimate Calculation}

Using models developed in this chapter a best-estimate calculation is made of tracer release fior the IFT-1 test conditions, for which tracer release data can be summarized as follows (sec Section 2):

Oxide Inventory

$$
\begin{aligned}
& \mathrm{DyO}_{3}=13.36 \mathrm{~g} \\
& \mathrm{~Tb}_{4} \mathrm{O}_{7}=1337 \mathrm{~g} \\
& \mathrm{Yb}_{2} \mathrm{O}_{3}=13.31 \mathrm{~g}
\end{aligned}
$$

Rare Earth Inventory

$$
\begin{aligned}
\text { Dy } & =1164 \mathrm{~g} \\
\mathrm{~Tb} & =1137 \mathrm{~g} \\
\mathrm{Yb} & =1169 \mathrm{~g} \\
\text { Total } & \approx 3473 \mathrm{~g}
\end{aligned}
$$

Making use of the hood and off-gas duct smear data, as well as scrub solution sampling data given in Reference 4, tracer release fractions for the IF $[-1$ test are estimated to be on the order of $2-4 \%$ as follows:

\begin{tabular}{ccccc} 
Specics & $\begin{array}{c}\text { Initial } \\
\text { Inventory,g }\end{array}$ & $\begin{array}{c}\text { Hood/Duct } \\
\text { Deposits, g }\end{array}$ & $\begin{array}{c}\text { Scrub } \\
\text { Solution, }\end{array}$ & $\begin{array}{c}\text { Maximum Fraction } \\
\text { Releasc }\end{array}$ \\
\cline { 2 - 4 } & 1164 & $4.7-6.2$ & 7.5 & $13.7 / 1164=0.012$ \\
$\mathrm{~Tb}$ & 1137 & $28.6-29.9$ & 14 & $43.9 / 1137=0.039$ \\
$\mathrm{Yb}$ & 1169 & $11.1-12.3$ & 17.5 & $\frac{29.8 / 1169=0.025}{\text { Averagc }=0 .(25)}$
\end{tabular}

These data are compared with predicted release fractions assuming carry-olf of tracers due to bubble rise through the melt, using the calculational methodology outlined in Table 9.

For present purposes, only those bubbles that are large enough to overcome convection entrainment effects but small enough to be removed from the influence of hydrodynamic instabilities and breakup, will be considered stable bubble carriers for tracer release-that is, bubble radii $\left(R_{1}\right)$ of $0.5102 .0 \mathrm{~cm}$. Predicted results are given in Table 10 at a viscosity of 30() poisc (lypical of INEL soil). As indicated, terminal bubble velocities (Step-2) of $V_{b}=0.4-6.4 \mathrm{~cm} / \mathrm{s}$ are estimated, with associated Reynolds numbers (Step-3) in the range of $\mathrm{Re} \approx(0 .(0) 3-(0.187$. Depending on diffusivity (D $=0.10-0.5 \mathrm{E}-6 \mathrm{~cm}^{2} / \mathrm{s} ;$ sec Appendix B), Peclet numbers of $\mathrm{Pe} \approx 10^{+5}-10^{+8}$ are estimated. 
Table 9. Calculational methodology for estimation of overall mass release fraction.'

Step-1. Bubble radii are determined from minimum/maximum criteria given in Sections $4.1 \& 4.2$.

Step-2. The characteristic bubble rise velocity is then estimated from Equation (9):

$$
V_{t, \text { rise }}=\left[\frac{2 \rho g R_{b}^{2}}{9 \mu}\right] .
$$

Step-3. Knowing bubble velocity, the effective bubbie Reynolds (Re) and Peclet (Pe) numbers are estimated:

$$
\operatorname{Re}=V_{b}\left(\rho_{1}\right) d_{b} / \mu \quad P e=V_{b} d_{b} / D
$$

Step-4. Having determined Re \& Pc, the appropriate expression for the Sherwood (Sh) number is applied, from which the mass iransport coefficient $\left(k_{m}\right)$ is estimated:

$$
k_{m}=\operatorname{Sh}(D) / d_{b} \text {. }
$$

Step-5. Estimates of the IFT-1 concentration (C) and surface area (A) conditions are then made, which when inserted into the generalized mass transfer equation give the mass release rate $\left(\mathrm{m}_{\text {rel }}\right)$ :

$$
m_{\text {rel }}(g / s)=k_{m} A\left(C_{\text {bulk }}-C_{\text {surface }}\right)
$$

Step-6. Knowing the release rate $\left(\mathrm{m}_{\text {rel }}\right)$ and the time $\left(\mathrm{t}_{\text {mell }}\right)$ at which the tracer material was subject to a melt environment, the total mass released $\left(\mathrm{M}_{\mathrm{ret}}\right)$ can be estimated:

$$
\mathrm{M}_{\mathrm{rel}}(\mathrm{g})=\mathrm{m}_{\mathrm{rel}}\left(\mathrm{t}_{\mathrm{melt}}\right)
$$

from which the release fraction (RF) can be estimated:

$$
\mathrm{RF}=\mathrm{M}_{\mathrm{rel}} \text { /Initial Inventory }
$$


Table 10. Best estimate calculational of tracer release fraction for the IFT-1 experiment.

ISV Melt Properties

Melt temperature $\left(\mathrm{T}_{\mathrm{mp}}\right)$

Melt density $(\rho)$

Melt viscosity $(\mu)$

Diffusion cocfficient (D)

Melt surface tension (o)

Mell surface area $(A)$

Gravitational constant
Value

$1447^{\circ} \mathrm{C}(1720 \mathrm{~K})$

$2.2 \mathrm{~g} / \mathrm{cc}$

$3(0)$ poise $(300) \mathrm{g} / \mathrm{s}-\mathrm{cm})$

$\approx 0.1$ to $0.5 \mathrm{E}-6 \mathrm{~cm}^{2} / \mathrm{s}$ (all species)

$\approx 1000 \mathrm{dy} / \mathrm{cm}$ (assumed)

$\approx(10-\mathrm{ft} \times 10-\mathrm{ft})=9.29 \mathrm{E}+4 \mathrm{~cm}^{2}$

$=980 \mathrm{~cm} / \mathrm{s}^{2}$

Bubble Velocity/Reynolds Number/Peclet Number

\begin{tabular}{ccccc}
\multicolumn{2}{c}{$\mathrm{V}_{\mathrm{b}}=2 R_{b}^{2} \mathrm{Q}_{\mathrm{L}} \mathrm{g} / 9_{\mu}$} & $\mathrm{Re}=\mathrm{V}_{\mathrm{h}} \rho \mathrm{d}_{\mathrm{b}} / \mu$ & $\mathrm{Pe}=\quad=\mathrm{V}_{\mathrm{b}} \mathrm{d}_{\mathfrak{b}} / \mathrm{D}$ \\
$\underline{\mathrm{d}}_{1 \mu \mathrm{cm}}$ & $\underline{\mathrm{V}}_{\mathrm{b},} \mathrm{cm} / \mathrm{s}$ & $\frac{\mathrm{Re}}{0.003}$ & $\frac{\operatorname{Pc}\left(\mathrm{D}=0.5 \mathrm{E}-6 \mathrm{~cm}^{2} / \mathrm{s}\right)}{8.0 \mathrm{E}+5}$ & $\frac{\operatorname{Pe}\left(\mathrm{D}=0.1 \mathrm{E}-6 \mathrm{~cm}^{2} / \mathrm{s}\right)}{4.0 \mathrm{E}+6}$ \\
1.0 & 0.40 & 0.0 & $5.1 \mathrm{E}+7$ & $2.6 \mathrm{E}+8$
\end{tabular}

Sherwood Number/Mass Transfer Coelficient

$$
\mathrm{Sh}=0.65 \mathrm{Pe}^{1 / 2} \quad \mathrm{k}_{\mathrm{m}}(\mathrm{cm} / \mathrm{s})=\operatorname{Sh}(\mathrm{D}) / \mathrm{d}_{\mathrm{b}}
$$$$
\underline{D}=0.5 \mathrm{E}-6 \mathrm{~cm}^{2} / \mathrm{s}
$$

\begin{tabular}{|c|c|c|}
\hline$\underline{d}_{\mu L} \mathrm{~cm}$ & Sh & $\mathrm{k}_{\mathrm{m}} \mathrm{cm} / \mathrm{s}$ \\
\hline 1.0 & 581 & $2.90 \mathrm{E}-4$ \\
\hline 4.0 & 4647 & $5.81 \mathrm{E}-4$ \\
\hline
\end{tabular}

$\mathrm{D}=0.1 \mathrm{E}-6 \mathrm{~cm}^{2} / \mathrm{s}$

$\frac{\mathrm{Sh}}{130 \mathrm{l}} \quad \frac{\mathrm{k}_{\mathrm{m} 2} \mathrm{~cm} / \mathrm{s}}{1.30 \mathrm{E}-4}$

IFT-1 Concentration and Melt Time Conditions

$\mathrm{I}_{\text {tric }}=$ Total tracer inventory $=3473 \mathrm{~g}$

$\mathrm{V}_{\mathrm{p} \text { (x)l }}=$ Melt volumc $=X_{\mathrm{ave}}(\mathrm{A})=(180 \mathrm{~cm})\left(9.29 \mathrm{E}+4 \mathrm{~cm}^{2}\right)=1.67 \mathrm{E}+7 \mathrm{~cm}^{3}$

$X_{1}=$ Melt pool depth at tracer location $=4 \mathrm{ft}=122 \mathrm{~cm}$

$\mathrm{X}_{2}=$ Maximum melt pool depth $=7.87 \mathrm{ft}=240 \mathrm{~cm}$

$X_{\text {ave }}=$ Average pool depth $\approx 180 \mathrm{~cm}$

$\mathrm{C}_{\text {bulk }}=\mathrm{I}_{\text {trac }} / \mathrm{V}_{\text {prosl }}=(3473 \mathrm{~g}) /\left(1.67 \mathrm{E}+7 \mathrm{~cm}^{3}\right)=2.08 \mathrm{E}-4 \mathrm{~g} / \mathrm{cm}^{3}$

$\mathrm{C}_{\text {surface }}=0$

$t_{\text {mell }} \approx(30 \mathrm{hr}-12.5 \mathrm{hr})=17.5 \mathrm{hr}=63,000 \mathrm{~seconds}$

Relcase Rate/Total Release/Relcasc Fraction

$\mathrm{m}_{\mathrm{rcl}}(\mathrm{g} / \mathrm{s})=\mathrm{k}_{\mathrm{m}}(\mathrm{A})\left(\mathrm{C}_{\text {bulk }}\right)=\mathrm{k}_{\mathrm{m}}\left(9.29 \mathrm{E}+4 \mathrm{~cm}^{2}\right)\left(2.08 \mathrm{E}-4 \mathrm{~g} / \mathrm{cm}^{3}\right)=19.32\left(\mathrm{k}_{\mathrm{m}}\right)$

$M_{\mathrm{rel}}(\mathrm{g})=\mathrm{m}_{\mathrm{rel}}\left(\mathrm{t}_{\text {melt }}\right)$

$\mathrm{RF}=\mathrm{M}_{\mathrm{rel}} /($ Initial Inventory $=3473 \mathrm{~g})$

$$
\mathrm{D}=0.5() \mathrm{E}-6 \mathrm{~cm}^{2} / \mathrm{s}
$$

$\underline{\mathrm{d}}_{12} \mathrm{~cm} \quad \underline{\mathrm{m}}_{\mathrm{rel} / \mathrm{g} / \mathrm{s}} \quad \underline{\mathrm{M}}_{\mathrm{rel} / \mathrm{g}}^{\mathrm{g}} \quad \mathrm{RF}$

$\begin{array}{cccc}1.0 & 0.0056 & 35.3 & 0.10\end{array}$

$\underline{D}=0.10 \mathrm{E}-6 \mathrm{~cm}^{2} / \mathrm{s}$

$\begin{array}{llll}4.0 & 0.0112 & 707 & 0.20\end{array}$

$\begin{array}{rrr}\underline{m}_{\text {rel } 2 \mathrm{~g} / \mathrm{s}} & \underline{\mathrm{M}}_{\text {rel } 2 \mathrm{~g}} & \frac{\mathrm{RF}}{0 .(0) 25} \\ 0 .(0) 50 & 3158 & 0.045 \\ 0.091 & 315 & 0.091\end{array}$


Since Reynolds numbers less than one are estimated $(\operatorname{Re}<1)$, the following expression is employed to estimate the Sherwood number (Step-4):

$\mathrm{Sh}=0.65 \mathrm{Pe}^{1 / 2} \quad$ for $\mathrm{Re}<1$

from which the mass transfer coefficient $\left(k_{m}\right)$ is estimated, yielding values on the order of $\mathrm{k}_{\mathrm{m}} \approx 10^{-4} \mathrm{~cm} / \mathrm{s}$.

The generalized mass transfer equation is then evaluated once the IFT-1 concentration and surface area (A) conditions are estimated. The surface area $(A)$ for tracer release is defined by the 10-ft $x 10-\mathrm{ft}\left(9.29 \mathrm{E}+4 \mathrm{~cm}^{2}\right)$ melt size for the IFT-1 test. Since the IFT-1 olf-gas collection system continuously sweeps released gases from the process hood, the tracer concentration $\left(\mathrm{C}_{\text {surface }}\right)$ at the ISV melt surface is taken to be zero.

The bulk tracer concentration in the melt $\left(\mathrm{C}_{\text {bulk }}\right)$ is estimated from the initial tracer inventory and the average melt depth which exposed tracer material to melt conditions; that is, the average between the tracer burial depth $(\approx 4 \mathrm{ft}, 125 \mathrm{~cm})$ and the final melt depth $(240 \mathrm{~cm})$. Predictions of the IFT-1 tracer concentration conditions indicate a bulk concentration on the order of $2.08 \mathrm{x}$ $10^{-4} \mathrm{~g} / \mathrm{cm}^{3}$ (see Table 10), which can be compared with solubility data indicating that the rare-earth oxides $\left(\mathrm{DyO}_{3}, \mathrm{~Tb}_{4} \mathrm{O}_{7}\right.$, and $\left.\mathrm{Yb}_{2} \mathrm{O}_{3}\right)$ and $\mathrm{PuO}_{2}$ would dissolve to at least $1.0 \mathrm{wt}-\%$ in $\mathrm{SiO}_{2}$-based melts (see Reference 5). Noting that the density of basaltic melts is on the order of $2.2 \mathrm{~g} / \mathrm{cn}^{3}$, the following tracer weight fraction is estimated for IFT-1:

$$
\frac{2.08 \times 10^{-4} \mathrm{~g}-\text { tracer }}{\mathrm{cm}^{3}-\mathrm{SiO}_{2}} \times \frac{\mathrm{cm}^{3} \times \mathrm{SiO}_{2}}{2.2 \mathrm{~g}-\mathrm{SiO}_{2}} \approx \frac{0.95 \times 10^{-4} \mathrm{~g} \text {-tracer }}{\mathrm{g}-\mathrm{SiO}_{2}} \approx 0.0095 \mathrm{wl}-\%
$$

Since the IFT-1 tracer weight fraction is well below the solubility limit $(1 \mathrm{wt}-\%)$ and since the tracers were added to the test pit in powder form, it is reasonable to assume that the tracers were dissolved in the melt on a molecular scale. Thus, the use of mass transport correlations assuming tracer molecular carry-off due to bubble escape is valid. For these conditions mass release rates on the order of $\mathrm{m}_{\mathrm{rel}} \approx 0.0025-0.0112 \mathrm{~g} / \mathrm{s}$ are estimated, depending on diffusivity and bubble size.

To estimate the total integral release, the time period associated with tracer exposure to melt conditions must be known. The melt time $\left(t_{\text {melt }}\right)$ is taken to be the time period from the point when tracer material was firs subjected to a melt environment to the time at which the IFT-1 test was terminated. As indicated in Figure 10, at about $12.5 \mathrm{hr}$, the $125 \mathrm{~cm}$ tracer burial position was first reached, while end of ISV melting was at about $30 \mathrm{hr}$. Having estimated these ISV test conditions, the total mass released $\left(M_{\text {rel }}\right)$ can be approximated as $M_{r e l}(g)=m_{\text {rel }}\left(t_{\text {melt }}\right)$, from which the release fraction (RF) can be estimated. Predicted tracer release fractions (RF) ranging from a low of $4.5 . \%$ $\left(D=0.10 \mathrm{E}-6 \mathrm{~cm}^{2} / \mathrm{s} ; \mathrm{d}_{\mathrm{b}}=1 \mathrm{~cm}\right)$, to a high of $20-\%\left(D=0.50 \mathrm{E}-6 \mathrm{~cm}^{2} / \mathrm{s} ; \mathrm{d}_{\mathrm{b}}=4 \mathrm{~cm}\right)$ are indicated. The low-end values compare favorably with an experimental release fraction of between 1.2 to $3.9-\%$. 

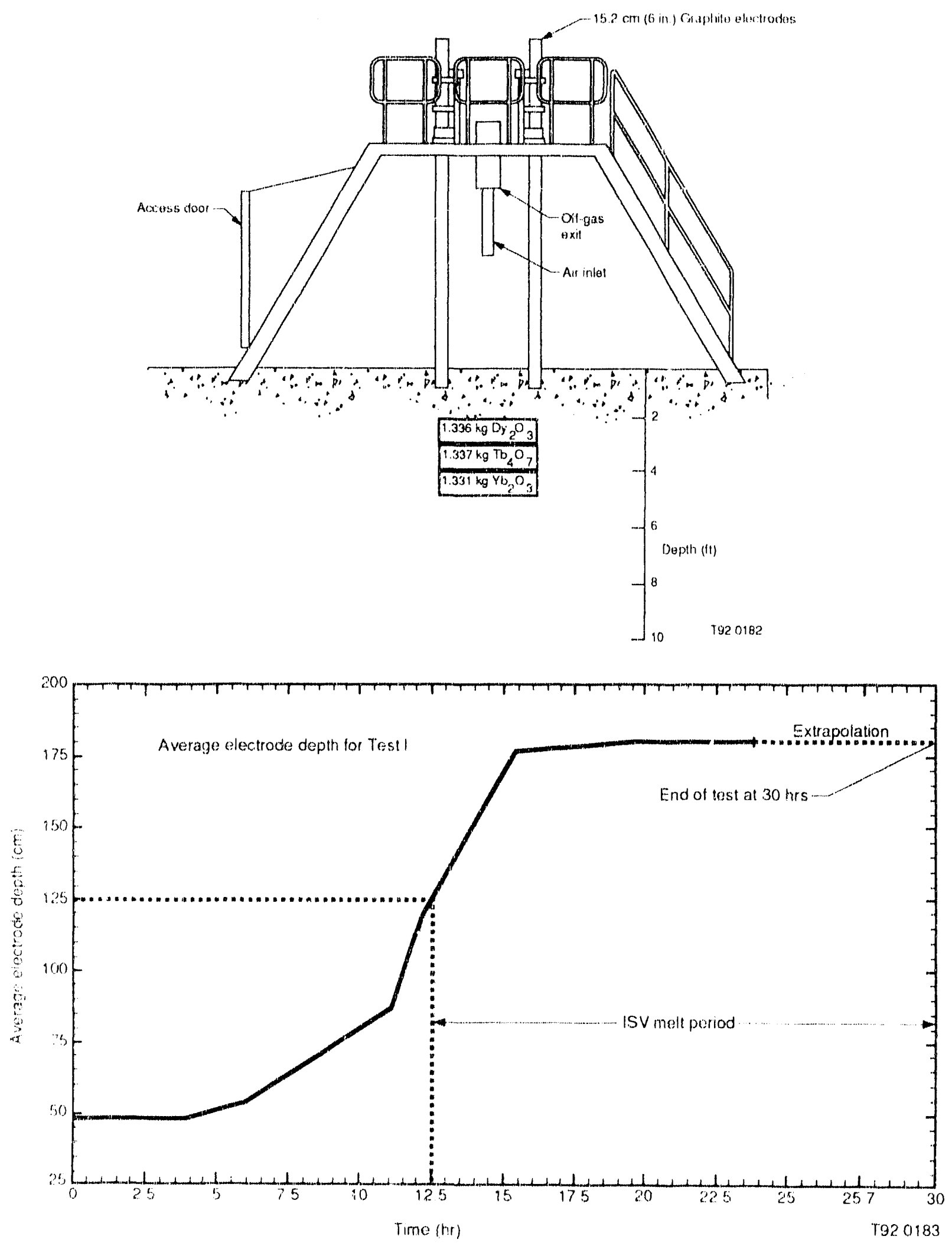

Figure 10. Summary of ISV IFT.1 test conditions. 


\subsection{Discussion of Results}

As indicated in Table 10, predicted tracer release fractions (RF) range from a low of $4.5 . \%$ for low diffusivities of $0.1 \mathrm{E}-6 \mathrm{~cm}^{2} / \mathrm{s}$ to a high of $20 . \%$ for high diffusivity $\left(0.5 \mathrm{E}-6 \mathrm{~cm}^{2} / \mathrm{s}\right)$ conditions. Since the IFT-1 off-gas collection system measurements indicate tracer release fractions ranging from 1.2 to $3.9 \%$, some calculational suceess is evident, albeit from an order-of-magnitude perspective. The best match between experimental findings and calculational predictions is for smallest bubble size ( $d_{h}$ $=1.0 \mathrm{~cm})$ and lowest diffusivity $\left(0.1 \mathrm{E}-6 \mathrm{~cm}^{2} / \mathrm{s}\right)$ used in these calculations. Both these values seem physically realistic, indicating that the observed tracer release behavior noted in the IFT-1 experiment can be accounted for by off-gassing effects.

It is interesting to note some of the nuances concerning modeling assumptions and the parameter values used. The underlying assumption of the analysis is that tracer release is due (n) molecular carry-off by escaping gas bubbles, so that the tracer dissolution in the melt is required. Predictions of the IFT-1 tracer concentration conditions indicate a bulk concentration on the order of $2.08 \times 10^{-4} \mathrm{~g} / \mathrm{cm}^{3}(0.0095 \mathrm{wt} \%)$, while solubility data indicate that the rare-earth oxides and $\mathrm{PuO}_{2}$ would dissolve to at least $1.0 \mathrm{wt}-\%$ in basaltic selts (see Reference 5). Since the estimated concentration is well below the solubility limit and since the tracers were added to the lesit pit in powder form, it is reasonable to assume that the tracers were dissolved in the melt on a molecular scale. Thus, the use of mass transport correlations assuming tracer molecular (atrry-ofli due to bubble: escape appears valid.

With respect to parameter uncertainties, specification of the cross-sectional area (A) of the ISV melt pool is somewhat uncertain sinee it varied during testing. However, the predicted mass release rate $\left(\mathrm{m}_{\mathrm{rel}}, \mathrm{g} / \mathrm{cm}\right)$ is independent of $\mathrm{A}$, as can be seen from inspection of the generalized mass transport equation:

$m_{\text {rel }}(g / s)=k_{m} A\left[C_{\text {bulk }}-\left(C_{\text {surface }}=0\right)\right]=k_{m} A\left(C_{\text {hulk }}\right)$

where

$C_{\text {hulk }}=I_{\text {trac }} / V_{\text {poot }}=I_{\text {trac }} J\left(V_{\text {porel }}=A \times\right.$ pool depth $)$.

Since the combined parameter $A\left(C_{\text {bulk }}\right)$ is a constant for constant pool depth, uncertainties in specification of the effective surface area $(A)$ do not impact overall predictions. The important dimensional parameter impacting cakculational results is the pool depth $\left(X_{\text {pxel }}\right)$, where the bulk concentration $\left(C_{\text {bulk }}\right)$ of the tracers within the melt pool varies indirectly with $X_{\text {pxot }}$. In the calculations presented, an average pool depth of $180 \mathrm{~cm}$ was chosen-that is, the average between the tracer burial depth $(\approx 4 \mathrm{ft}, 125 \mathrm{~cm})$ and the final melt depth $(240 \mathrm{~cm})$, where litte uncerainty exists with respect to these test conditions.

It is also noted that different correlations for the Sherweod number (Sh) due to buble rise have been suggested in the literature. A comparison of predictions for Sh are given in Table 11 employing Equations (16) and (17); while Equation (18) is not used since it applics for Reynolds numbers outside the present range. Calculational results indicate differences on the order of $\approx 2$ (0) 6 . which is within the range of uncertainties associated with estimation of melt prepertics and lest conditions. 
Table 11. Estimation of various mass transfer correlations for the Sherwood number and mass transfor coefficient.

Sherwood Number Correlations

$$
k_{m}=\operatorname{Sh}(D) / d_{b}
$$

Eq.A $\quad S h=0.65 \mathrm{Pe}^{1 / 2}$

Eq. B $\quad S h=1.13\left(P e^{1 / 2}\right)\left[\frac{d_{b}}{0.45+0.2 d_{b}}\right]$

$$
D=0.10 \mathrm{E}-6 \mathrm{~cm}^{2} / \mathrm{s} \quad \mu=300 \mathrm{~g} / \mathrm{s}-\mathrm{cm}
$$

\begin{tabular}{|c|c|c|c|c|c|c|}
\hline \multirow[b]{2}{*}{$\mathrm{d}_{12} \mathrm{~cm}$} & \multirow[b]{2}{*}{$\mathrm{Pe}$} & \multicolumn{2}{|c|}{ Sherwood Number } & \multicolumn{2}{|c|}{$\mathrm{k}_{\mathrm{m}}, \mathrm{cm} / \mathrm{s}$} & \multirow{2}{*}{$\begin{array}{l}\text { Ratio } \\
\text { A/B }\end{array}$} \\
\hline & & Eq.A & Eq. B & Eq. A & Eq. B & \\
\hline 1.0 & $4.00 \mathrm{E}+6$ & 1300 & 3480 & $1.30 \mathrm{E}-4$ & $3.48 \mathrm{E}-4$ & 2.68 \\
\hline 4.0 & $2.56 \mathrm{E}+8$ & 10400 & 57800 & $2.60 \mathrm{E}-4$ & $1.45 E-3$ & 5.56 \\
\hline
\end{tabular}


It is evident that a more precise time-dependent estimate could be obtained by assessing an instantaneous value for the mass release rate $\left(\mathrm{m}_{\text {rel }}, \mathrm{g} / \mathrm{s}\right)$ using a time-dependent melt depth, and then integrating over the entire period of testing. This would yield a high release rate at the initial 4. ft burial depth, and a lower release rate at the maximum ISV depth reached. However, for order-ofmagnitude estimates, use of an average melt depth of $180 \mathrm{~cm}$ is reasonable.

The principal parameter influencing calculational uncertainties, therefore, appears to be the absence of tracer diffusivity (D) data for $\mathrm{SiO}_{2}$-based melts. Until such data become available, exact predictions on tracer release cannot be made. Nevertheless, it is encouraging that predictions (sce Appendix B) of the diffusivity of the tracers $\mathrm{Dy}_{2} \mathrm{O}, \mathrm{Tb}_{4} \mathrm{O}_{7}$, and $\mathrm{Yb}_{2} \mathrm{O}_{3}$ in $\mathrm{SiO}_{2}$ melts yield values on the order of $10^{-6} \mathrm{~cm}^{2} / \mathrm{s}$, similar to that used in the above calculation. A comparison of predicted (Appendix B) and published ${ }^{14}$ diffusivities in soil melts is given in Table 12. As indicated, the diffusivities used in the mass transport calculations (D $=0.1-0.5 \mathrm{E}-6 \mathrm{~cm}^{2} / \mathrm{s}$ ) given in Table 10 are within the range of published diffusivitics. Thus, some predictive suceess is apparent in modeling the IFT-1 tracer release data. Because of a similar diffusivity for $\mathrm{PuO}_{2}$, similar release of plutonium might also be expected.

One last point that should be noted concerns the use of well-established mass transport correlations for bubble rise through liquids. Evidence for bubble escape from the ISV melt is illustrated in Figure 11, which was taken from a video photographic at the ISV melt surface. As indicated, an elliptical shape is evident in Figure 11. Although spherical bubbic geometry can be assumed for the melt interior, the formation of elliptical vapor domes at the melt surface is due 10 differences in surface tension forces for the underside of the vapor dome versus that at the upper thin-film gas/liquid interface. Over-pressurization and cyclic bursting of such surface bubbles thus leads to gas and associated tracer release. Since the formation of the surface bubble occurs as a result of the agglomeration of numerous gas bubbles rising through the mell (carriers for tracer transport), the limiting condition for tracer release is assumed to be associated with spherical bubble rise from the melt interior to the surlace. It is from this perspective that well-established mass transport correlations for spherical bubble rise through liquids were employed in the prediction of tracer release for the IFT-1 test. 
Table 12. Comparison of predicted and published diffusivities for molten soil materials.

System (Melts)

$\mathrm{Ca}$ in $\mathrm{CaO}-\mathrm{Al}_{2} \mathrm{O}_{3}-\mathrm{SiO}_{2}$ $(40 / 20 / 40)$

$\mathrm{Si}$ in $\mathrm{CaO}-\mathrm{Al}_{2} \mathrm{O}_{3}-\mathrm{SiO}_{2}$ $(40 / 20 / 40)$

$\mathrm{Fe}$ in $\mathrm{CaO}-\mathrm{Al}_{2} \mathrm{O}_{3}-\mathrm{SiO}_{2}$ $(30 / 15 / 55)$

$\mathrm{Fc}$ in $\mathrm{CaO}-\mathrm{Al}_{2} \mathrm{O}_{3}-\mathrm{SiO}_{2}$ $(43 / 22 / 35)$

$\mathrm{Tb}_{4} \mathrm{O}_{7}$ in $\mathrm{SiO}_{2}$

$\mathrm{Dy}_{2} \mathrm{O}_{3}$ in $\mathrm{SiO}_{2}$

$\mathrm{Yb}_{2} \mathrm{O}_{3}$ in $\mathrm{SiO}_{2}$

$\mathrm{PuO}_{2}$ in $\mathrm{SiO}_{2}$
Diffusivily, $\mathrm{cm}^{2} / \mathrm{s}$

$0.62 \times 10^{-6}$

$0.1 \times 10^{-6}$

$0.24-0.31 \times 10^{-5}$

$0.21-0.50 \times 10^{-5}$

$0.313 \times 10^{-6}$

$0.536 \times 10^{-6}$

$0.560 \times 10^{-6}$

$0.831 \times 10^{-6}$
Method

a

a

Predicted

Predicted

Predicted

Predicted

a. G. H. Geiger and D. R. Poirier, Transport Phenomena in Metallurgy, Addison-Wesley Pub. Co., Reading, MA (1973).

Predicted: see Appendix B. 


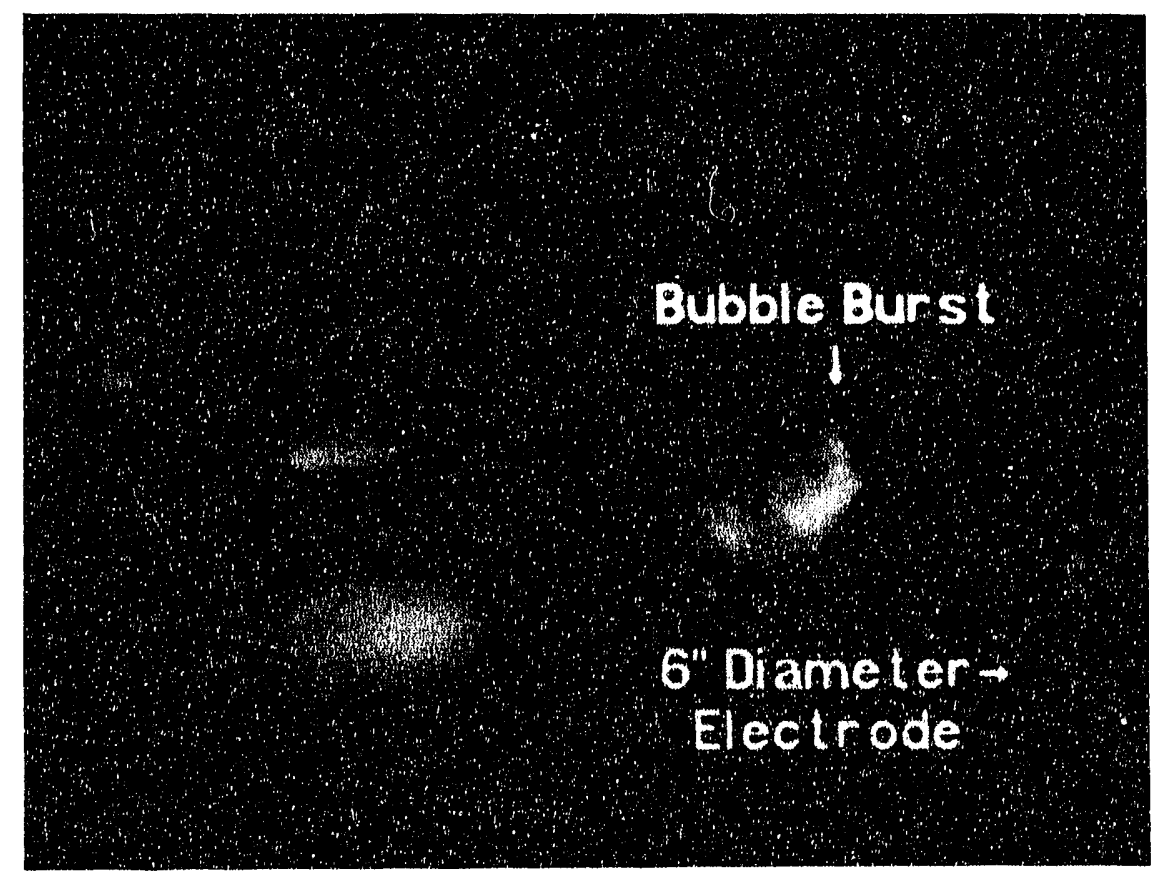

Figure 11. Photographic evidence of bubble bursting at ISV melt surface. 


\section{COMPARISON OF THE IFT-1 AND IFT-2 TRACER RELEASE TRENDS}

Analysis presented in the preceding sections indicate that some tracer release can be expected to accompany off-gassing from ISV melts. Using standard mass transport correlations for bubble rise from liquids, release estimates for the IFT-1 test (tracer release $=1.2$ to $3.9 \%$, depending on tracer type) range from a low of $4.5-\%$ for low diffusivity/small bubble $\left(D=0.1 \mathrm{E}-6 \mathrm{~cm}^{2} / \mathrm{s} ; \mathrm{d}_{\mathrm{b}}=1.0 \mathrm{~cm}\right)$ conditions, to a high of $20 \%$ for the high diffusivity/large bubble case $\left(D=0.5 \mathrm{E}-6 \mathrm{~cm}^{2} / \mathrm{s} ; \mathrm{d}_{\mathrm{b}}=\right.$ $4 .(\mathrm{cm})$. Thus, some calculational success is evident, albeit from an order-ol-magnitude perspective. The best match between the test data and calculational predictions is for the smallest bubble size $\left(d_{h}=1.0 \mathrm{~cm}\right)$ and lowest diffusivity $\left(0.1 \mathrm{E}-6 \mathrm{~cm}^{2} / \mathrm{s}\right)$ used in these calculations. The conclusion is thus made that the release of rare-earth tracers, can be attributed to tracer carry-off by escaping gas (either water vapor or noncondensibles). The question, then, is why similar tracer release did not occur for the IFT-2 experiment, where consideration is given to differences in test conditions with respect to the tracer type employed, concentration and tracer placement conditions, as well as differences in the extent of off-gassing for the two tests.

Table 13 presents a summary of waste pit inventory conditions for the IFI-1 and IFT-2 experiments. In the IFT-1 test, the rare-earth oxides of $\mathrm{Dy}_{2} \mathrm{O}_{3}, \mathrm{~Tb}_{4} \mathrm{O}_{7}$, and $\mathrm{Yb}_{2} \mathrm{O}_{3}$ were added 10 the test pit to simulate $\mathrm{PuO}_{2}$ behavior during ISV melting; however, only $\mathrm{Dy}_{2} \mathrm{O}_{3}$ was used in the IFT-2 experiment. It is also noted that the IFT-2 test pit contained about twice the inventory of $\mathrm{Dy}_{2} \mathrm{O}_{3}$ than in IFT-1, but no $\mathrm{Tb}_{4} \mathrm{O}_{7}$ or $\mathrm{Yb}_{2} \mathrm{O}_{3}$.

With respect to tracer type, differences in molecular transport properties could have inlluenced release behavior. Although diffusivity data are unavailable for the particular tracers used in the IFT experiments, diffusivities predicted in Appendix $\mathrm{B}$ range from $\approx 0.3 \mathrm{E}-6 \mathrm{~cm}^{2} / \mathrm{s}$ for $\mathrm{Tb}_{4} \mathrm{O}_{7}$ to $\approx 0.56 \mathrm{E}-6$ $\mathrm{cm}^{2} / \mathrm{s}$ for $\mathrm{Yb}_{2} \mathrm{O}_{3}$, which is less than a factor of two difference. Thus, it is difficult to explain the large variations in release noted between the two IFT experiments, based on cifferences in diffusivities. Likewise, similar chemical properties for $\mathrm{Dy}_{2} \mathrm{O}_{3}, \mathrm{~Tb}_{4} \mathrm{O}_{7}$, and $\mathrm{Yb}_{2} \mathrm{O}_{3}$ have been noted (see Reference 5), so that minor differences in tracer properties would not account for the large disparity in release noted between the IFT-1 and IFT-2 tests.

Another lactor which could have influenced release behavior is due to concentration effects. Inspection of the governing equation for mass transport indicates that the release rate is directly proportional to concentration:

$m_{r(c)}=k_{m} A\left(C_{\text {bulk }}-C_{\text {surface }}\right)$

As indicated in Table 13, the total tracer inventory for IFT-1 was $4.0(4) \mathrm{kg}$ versus $2.282 \mathrm{~kg}$ for IFT-2, while the soil overburden for IFT-2 was twice that of IFT-1. Thus, the tracer concentration for IFT-2 is estimated to be about one-fourth that of IFT-1, with a corresponding similar decrease in the release rate $\left(\mathrm{m}_{w \mathrm{e}}\right)$ for IFT-2 compared to IFT-1, all other factors being equal. The one-fourth difference in concentration does not explain nil release for IFT-2 versus 2 to $4-\%$ release for IFT-1. 
Table 13. Waste inventory in the IFT-1 and IFT-2 experiments.

\begin{tabular}{|c|c|c|}
\hline \multirow[b]{2}{*}{ Material } & \multicolumn{2}{|c|}{ Inventories } \\
\hline & IFT -1 & IFT-2 \\
\hline \multicolumn{3}{|l|}{ Waste Materials } \\
\hline Combustible & $666 \mathrm{lb}$ & $1,514 \mathrm{lb}$ \\
\hline Water & $478 \mathrm{lb}$ & $1,035 \mathrm{lb}$ \\
\hline FLOOR-DEI & $4.3 \mathrm{lb}$ & $94 \mathrm{lb}$ \\
\hline MICRO-CELL & $143 \mathrm{lb}$ & $308 \mathrm{lb}$ \\
\hline Metal & $2,473 \mathrm{lb}$ & $6,758 \mathrm{lb}$ \\
\hline Glass & $485 \mathrm{lb}$ & $237 \mathrm{lb}$ \\
\hline Concrete & $867 \mathrm{lb}$ & $6(x) \mathrm{lb}$ \\
\hline \multicolumn{3}{|l|}{ Tracers } \\
\hline $\mathrm{Dy}_{2} \mathrm{O}_{3}$ & $1.336 \mathrm{~kg}$ & $2.282 \mathrm{~kg}$ \\
\hline $\mathrm{Tb}_{4} \mathrm{O}_{7}$ & $1.3 .37 \mathrm{~kg}$ & $\cdots$ \\
\hline $\mathrm{Yb}_{2} \mathrm{O}_{3}$ & $1.331 \mathrm{~kg}$ & $\ldots$ \\
\hline Tracers (total) & $4.004 \mathrm{~kg}$ & $2.282 \mathrm{~kg}$ \\
\hline \multicolumn{3}{|l|}{ Soil } \\
\hline Soil Fill & $54,630 \mathrm{lb}$ & $49,963 \mathrm{lb}$ \\
\hline Soil Overburden & $2 \mathrm{ft}$ & $4 \mathrm{ft}$ \\
\hline
\end{tabular}

Although the direct effects of burial depth are not apparent from IFT-1 tracer release data, c.g.,:

\begin{tabular}{|c|c|c|}
\hline Species & Release Fraction & Burial Dopth \\
\hline$\overline{\mathrm{Dy}_{2} \mathrm{O}_{3}}$ & 0.012 & $\approx 2 \mathrm{ft}$ \\
\hline $\mathrm{Tb}_{4} \mathrm{O}_{7}$ & 0.039 & $\approx 3.5 \mathrm{ft}$ \\
\hline $\mathrm{Yb}_{2} \mathrm{O}_{3}$ & 0.025 & $\approx 5 \mathrm{ft}$ \\
\hline
\end{tabular}

it is noteworthy that differences in relative placement of tracer and vaporous material can be correlated to greater tracer release in IFT-1 than in IFT-2. As indicated in Figure 12, tracer materials for IFT-1 were placed 2 to $5 \mathrm{ft}$ below the surface, with combustible and sludge material distributed between 2 and $9 \mathrm{ft}$ from the surface. Thus, from the time when the tracer material was first exposed to melting and thereafter, vapors would have been continuously available for carry-off of the tracers. In the IFT-2 test, the $\mathrm{Dy}_{2} \mathrm{O}_{3}$ tracer was buried at about $5 \mathrm{ft}$, with combustible and sludge material distributed over a limited depth of between 4 to $7 \mathrm{ft}$. Thus, only during melting at $5.7 \mathrm{ft}$ would the IFT-2 tracer material have been exposed to vapor generation. The smaller 2 fi soil overburden for IFT-1 versus 4 ft for IFT-1 may also have impacted overall release behavior. , ththough such relative placement effects may not completely explain differences in tracer release behavior noted for the two experiments, the tracer release trends do correlate to such burial depth effects. 

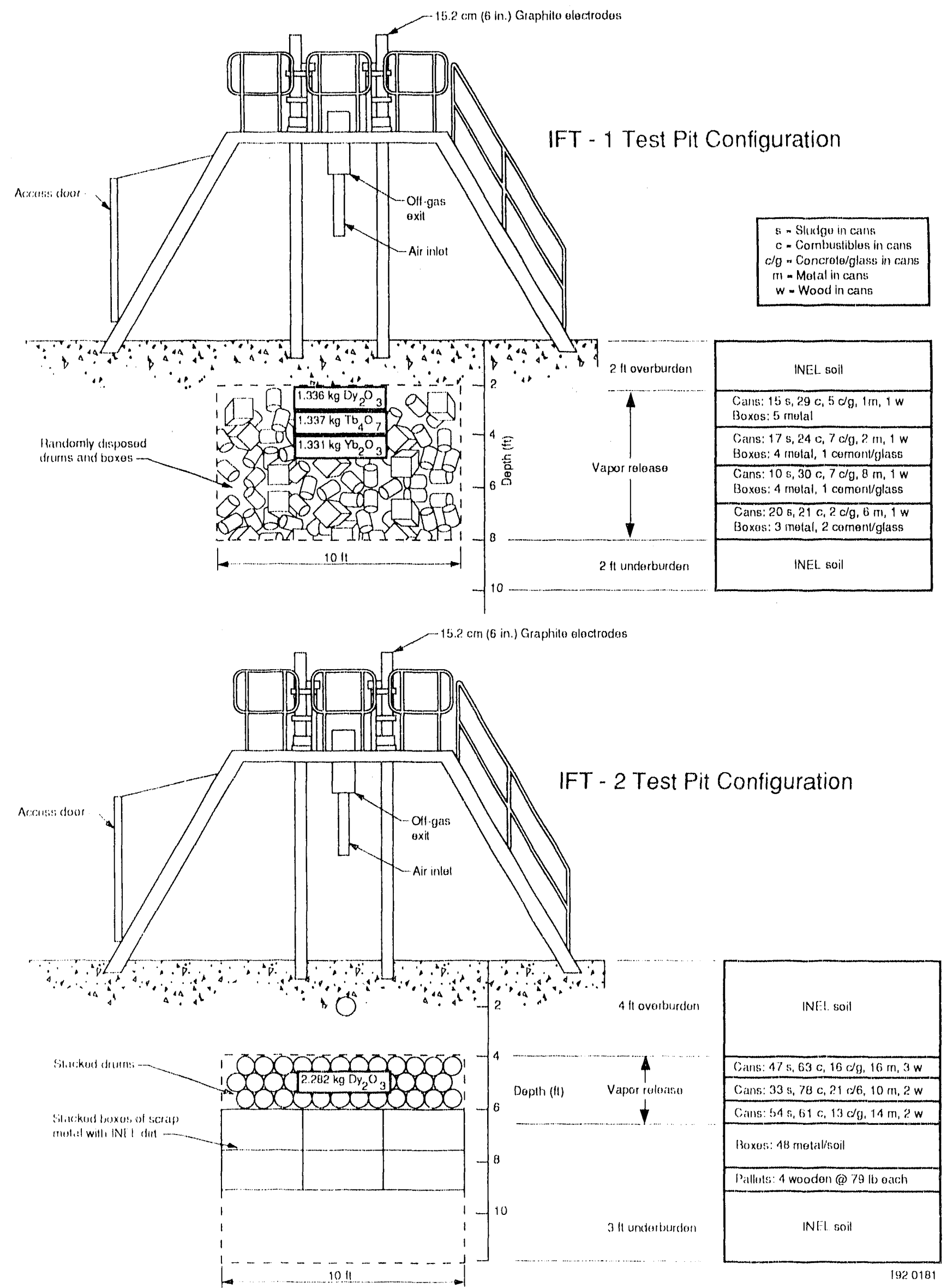

Figure 12. Illustration of relative burial positioning for tracer and vaporous materials for the IFT-1 and IFT-2 experiments. 
Another noteworthy factor is that although IFT-2 contained potentially more volatiles than IFT-1 (see Table 13), the amount of released gas in IFT-2 appeared to be much less than in IFT-1. Though direct measurements of off-gassing are not available, qualitative estimates of gas release can be deduced from Figure 13, where a comparison of hood temperature and vacuum pressure measurements are presented for the two experiments. The data for IFT-2 show three negative spikes in hood vacuum pressure and a corresponding temperature increase, indicative of three major gas release cvents. By comparison 14 spiking events are noted for IFT-1, suggesting a more frequent and dynamic off-gassing process in IFT-1. The greater anount of off-gassing noted for IFT-1 is consistent with the experimental observation of greater tracer release by escaping gas.

The reason for greater gas release in IFT-1 compared to IFT-2 is not obvious. Such factors as a faster melting rate and less soil overburden in IFT-1 compared to IFT-2 may have contributed to enhanced off-gassing in IFT-1, in spite of the fact that IFT-2 contained more than twice the inventory of combustible and sludge (water + FLOOR DRI + MICRO-CEL) matcrials.

One other noteworthy comment relates to the difference in gas release modes illustrated in Figure 14, namely gas escape in the form of small-volume bubbles versus large-volume/slug-type release. In the analysis presented, gas release was assumed in the form of spherical gas bubbles, for which well-established correlations are available for estimation of the Sherwood number (Sh) and associated mass transfer coefficient $\left(\mathrm{k}_{\mathrm{m}}\right)$. The data in Figure 13, however, indicate sudden gas release, related to hood pressure spiking and concurrent temperature rise. Under transient gas release conditions, standard Sherwood number correlations would not apply, where tracer release would be expected to depend on both the quantity of released gas and ejected melt. The fact that iracer deposits (see Reference 4, pp. 241-242) were found within the IFT-1 high-efficiency particulate air (HEPA) filter (located within the air inlet pipe to the process hood) is indicative of at least some tracer release by sudden/large-volume gas release, since positive hood pressures would have been required to foree tracer material upstream through the air inlet pipe resulting in deposition onto the HEPA filters. Although characterization of such transient gas release is beyond the scope of this study, it should be recognized that such slug-type release would also contribute to the overall release of tracer materials.

Although uncertainties exist, the tracer release trends from assessment of the IFT test data can be correlated to mass transport due to gas escape. Likewise, since the thermochemical (sec Reference 5) and transport properties (see Appendix $\mathrm{B}$ ) of $\mathrm{PuO}_{2}$ are similar to that of the rare-earth oxides ( $\mathrm{Dy}_{2} \mathrm{O}, \mathrm{Th}_{4} \mathrm{O}_{7}, \mathrm{Yb}_{2} \mathrm{O}_{3}$ ) used in the IFT tests, similar release of $\mathrm{PuO}_{2}$ is predicted. The conclusion is thus made that some release of rare-earth and plutonium oxides can be expected for conditions where significant off-gassing accompanies ISV processing. 

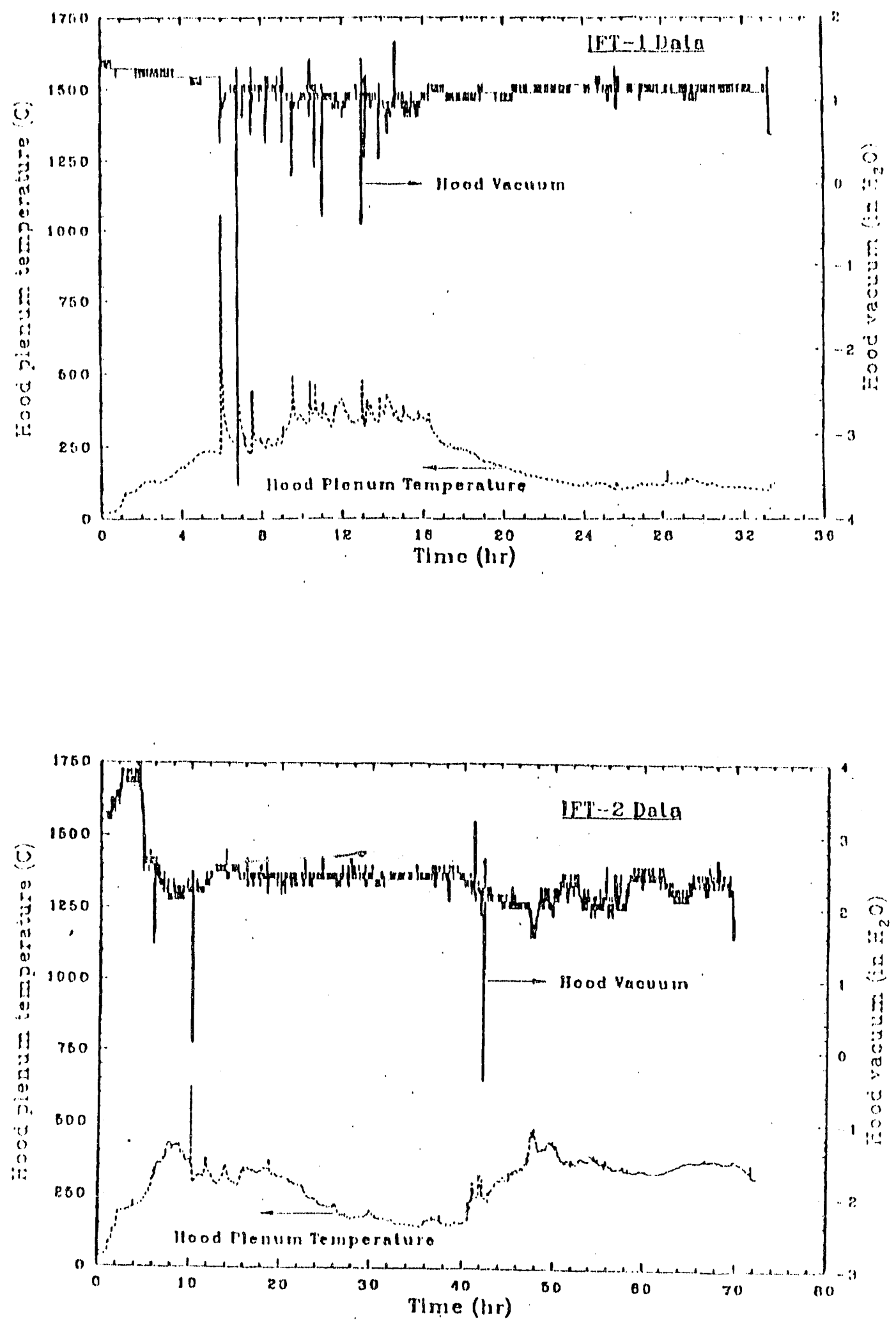

Figure 13. Comparison of measured hood pressure and temperatures noted in IFT-1 and IFT-2. 


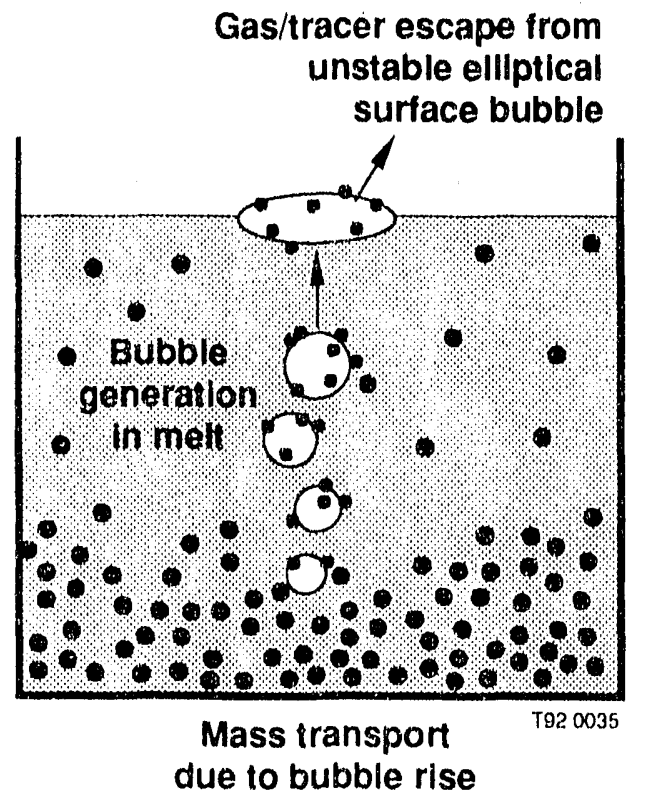

Gas escape by quiescent bubble rise from the melt.

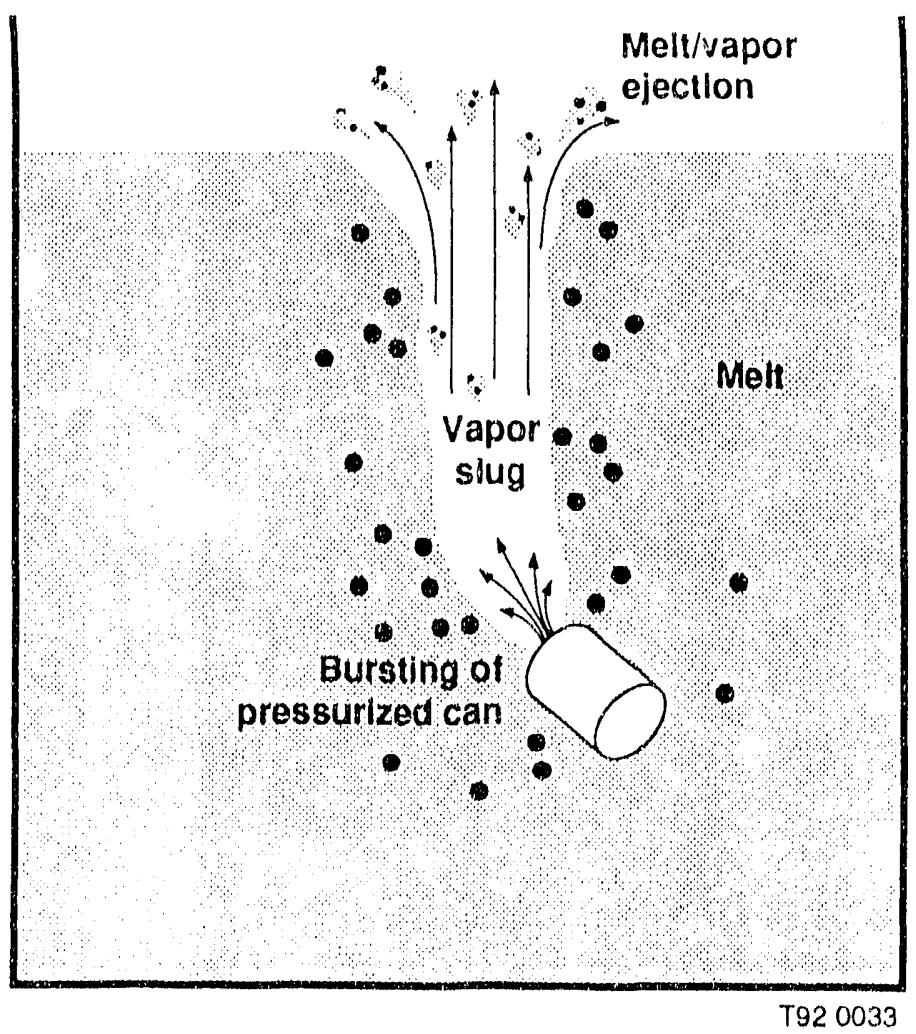

Gas escape and melt ejection duc to transient slug-type vapor relcase.

Figure 14. Illustration of gas escape by bubble rise, versus transient slug-type gas releasc. 


\section{SUMMARY AND CONCLUSIONS}

Test data on tare-earth oxide release during ISV were examined for the first two Intermediate Field Tests (IFT) conducted at the Idaho National Engineering Laboratory (INEL). In these experiments, small quantities of rare-earth oxides $\left(\mathrm{Dy}_{2} \mathrm{O}_{3}, \mathrm{Yb}_{2} \mathrm{O}_{3}\right.$, and $\mathrm{Th}_{4} \mathrm{O}_{7}$-referred to as tracer material) were added to the test pits to simulate buried transuranic waste (i.e., $\mathrm{PuO}_{2}$ ). In the lirst test, IFT-1, approximately 4-\% release of such tracers occurred during soil melting and associated offgassing, while essentially nil release was observed for the IFT-2 experiment. Within this report an assessment is made of processes which could explain such differences in tracer release behavior.

To quantify tracer release behavior, an order-ol-magnitude assessment was made of three potential transport mechanisms for ISV melt environments-tracer diffusion through a stagnant pool, tracer transport by convective currents due to melt internal heating, and tracer carry-off by escaping gas bubbles. Analysis indicates that tracer carry-off by gas bubbles would be the dominant release mechanism during ISV melting. A detailed assessment of this mechanism was thus pursued to benchmark the IFT tracer release data.

Predictions of tracer release for the IFT-1 experiment were mertr based upon an assessment of bubble size requirements for release, bubble growth and coaleser ece behavior, and an evaluation of empirically-based mass transport correlations for bubble release from liquids. At melt viscosities of $3(x)$ poise, bubble diameters of $1 \mathrm{~cm}$, and tracer diffusivities of $\approx 10^{-6} \mathrm{~cm}^{2} / \mathrm{s}$, reasonably good comparison between predicted tracer release behavior and the IFT-1 lest data were obtained. Since these parameters appear to be physically realist:; good comparison between theory and the IFT-1 data are apparent, albeit from an order-of-magnitude perspective.

The principal parameter influencing calculational uncertainties appears to be the absence of diffusivity data for $\mathrm{SiO}_{2}$-based melts. However, predicted diffusivities for $\mathrm{Dy}{ }_{2} \mathrm{O}, \mathrm{Th}_{4} \mathrm{O}_{7}, \mathrm{Yb}_{2} \mathrm{O}_{3}$, and $\mathrm{PuO}_{2}$ in $\mathrm{SiO}_{2}$-based melts yield values of $\approx 0.3 \times 10^{-6}$ to $0.5 \times 10^{-6} \mathrm{~cm}^{2} / \mathrm{s}$, which compare well with published data for $\mathrm{Fe}$ and $\mathrm{Ca}$ ion diffusivities in $\mathrm{SiO}_{2}$-based melts. Since $\mathrm{PuO}_{2}$ has similar chemical and transport (diffusivity) properties as the rare-earth oxides, release of $\mathrm{PuO}_{2}$ can also be predicted for the IFT-1 test under similar off-gassing conditions.

An attempt was made to assess the differences in tracer release behavior for the IFT-1 and IFT-2 experiments. Although IFT-2 contained potentially more volatiles than IFT-1, the extent of off-gassing in IFT-2 was much less than for IFT-1, based on hood pressure and temperature measurements. The reduced amount of both off-gassing and tracer release in IFT-2 is consistent with analysis results, indicating tracer transport tied to ofl-gassing. The hood pressure and temperature measurements for IFT-1 may also indicate large-volume transient gas release during portions of that test. For such transient gas release, standard mass transport corrclations do not apply; rather, the amount of released tracer material may best correlate to both the quantity of ejected melt and gas released. Nevertheless, no matter which gas release mechanism applies, the IFT-1 and IFT-2 tracer relcase trends can be correlated to some form of gas escape, so that the following conclusions are made.

- Rare-earth tracer release data can be correlated to gas escape during ISV melting. 
- Release of $\mathrm{PuO}_{2}$ can be expected for similar off-gassing conditions, since its chemical and transport propertics are similar to that of the rare-earth oxide tracers used in the IFT experiments.

- Uncertainties in predicted rare-earth oxide and $\mathrm{PuO}_{2}$ release associated with bubble rise through molten soil are largely due to lack of diffusivity data for such species in soil melts.

- $\quad$ Reduced off-gassing during ISV processing of buried waste should lead to improved retention of heavy-oxides within vitrified soil.

- Further investigation is suggested on tracer release for transient gas escape and molt ejection. 


\section{REFERENCES}

1. R. A. Callow, L. E. Thompson, and J. R. Weidner, In Situ Vitrification of Buried Waste: Interim Repori of Intermediate Field Tests at ldaho National Engineering Laboratory, EGG-WTD-9422, Rev. 1, February 1991.

2. J. L.. Buclt et al., In Sim Vitrification of Transuranic Wastes: Systems Evaluation and Applications Assessment. Batlclle Pacific Northwest Laboratory Report, PNL-48(K), Supplement 1, 1987.

3. A. W. Cronenberg, R. Callow, and R. McAtec, "Use of Rare Earth Tracers as Pu Surrogates in ISV Studies," Proc. Waste Management y2 Symposium, Tucson, AZ, March 1-5, 1992.

4. R. A. Callow et al., In Situ Vitrificution Applicution to Buried Waste: Final Report of Intermediate Field Tests at Idaho National Engineering Laboratory, EGG-WTD-9807, August $[(x) 1$.

5. R. E. McAtee and M. Beal, Comparison of the High Temperature Chemistry of Plutonium and Rare Earths: A Review Study, EGG-WTD 9801 , September 1991.

6. J. E. Flinn et al., Anmual Repon on TRU Waste Form Studies with Special Reference to IronEnriched Basalt, EGG.FM-5366, 1981.

7. B. Heshmatpour, G. L. Copeland, and R. L. Heestand, Decontamination of Transuranic Waste by Melt Refining, ORNL/TM-7951, 1981.

8. C. W. Hobbick, D. R. Schaltz, and G. D. Aden, Distribution and Remon'al of Radionuclides in Molten Stainless Steel, RHO-CD-1 144, 1981.

9. D. A. Petti et al., "Analysis of Fission Product Relcase Behavior from the TMI-2 Core," J. Nucl. Technology (87), pp. 24.3-263, August 1989.

10. V. (i. Levich, Physiconhemical Hydrodynamics, Prentice Hall, pp. 452.454, 1962.

11. D. A. Powers, J. E. Brockmann, and A. W. Shiver, "VANESA: A Mechanistic Model for Radionuclide Release and Aerosol Generation During Core Debris Interactions with Concrete," NUREG/CR-4.308, SAND85-1.370, July 1986.

12. D. R. Olander, Fundamental Aspects of Nuclear Reactor Fuel Elements, U.S. Energy Rexcarch and Development Administration Publication, 1976.

13. T. K. Sherwoed, R. L.. Pigford, and C. R. Wilke, Mass Transfer, McGraw-Hill Book Co, New York. pp. 231-234. 1975.

14. G. H. Geiger and D. R. Poirier, Trangport Phenomena in Metallurgen, Addison. Wesley Pub. (o., Reiding, MA, 1973. 


\section{Appendix A}

Soil Melt Properties for Transport Modeling 


\section{Appendix A}

\section{Soil Melt Properties for Transport Modeling}

Important to an accurate prediction of tracer or $\mathrm{PuO}_{2}$ molecular transport in molten soil is knowledge of melt physical properties, of which the following are of primary importance and summarized in this appendix.

- soil chemical composition - density

- lusion temperature viscosity

- thermal conductivity - surface tension

- $\quad$ specific heat

\section{A.1 Chemical Composition}

Samples of the uncontaminated soil from INEL burial sites have been analyzed to determine inorganic composition, ${ }^{1,2}$ with results summarized in Table A 1 . The INEL soil samples were found 10 have a relatively high weight content of $\mathrm{SiO}_{2}$ and $\mathrm{Al}_{2} \mathrm{O}_{3}$. The addition of approximately 5 wt $\%$ $\mathrm{Na}_{2} \mathrm{O}$ (as $\mathrm{Na}_{2} \mathrm{CO}_{3}$ ) was shown to reduce the melting point by about $100^{\circ} \mathrm{C}$ and substantially decreased the viscosity, as is evident from the data presented in Table A-2 (see Reference 2).

Table A-1. Composition results of INEL soil analyses.

Oxide Composition, wt $\quad$ C

\begin{tabular}{|c|c|}
\hline $\mathrm{SiO}_{2}$ & 62.60 \\
\hline $\mathrm{Al}_{2} \mathrm{O}_{3}$ & 11.8 .5 \\
\hline $\mathrm{Fc}_{2} \mathrm{O}_{3}$ & 4.25 \\
\hline $\mathrm{CaO}$ & 3.68 \\
\hline $\mathrm{K}_{2} \mathrm{O}$ & 2.99 \\
\hline $\mathrm{MgO}$ & 1.72 \\
\hline $\mathrm{Na}_{2} \mathrm{O}$ & 1.37 \\
\hline $\mathrm{TiO}_{2}$ & 0.68 \\
\hline $\mathrm{MnO}_{2}$ & 0.10 \\
\hline $\mathrm{BaO}$ & 0.09 \\
\hline $\mathrm{ZrO}_{2}$ & 0.05 \\
\hline $\mathrm{B}_{2} \mathrm{O}_{3}$ & 0.05 \\
\hline $\mathrm{NiO}$ & 0.04 \\
\hline $\mathrm{SrO}$ & 0.02 \\
\hline $\mathrm{Cr}_{2} \mathrm{O}_{3}$ & 0.112 \\
\hline Total Oxide & $89.5 \%$ \\
\hline Moisture & $7.5 \%$ \\
\hline
\end{tabular}


Table A-2. INEL soil melt properties with $\mathrm{Na}_{2} \mathrm{O}$ addition.

\begin{tabular}{lll}
\multicolumn{1}{c}{ Property } & \multicolumn{1}{c}{ INEL Soil } & $\begin{array}{c}\text { INEL Soil } \\
\text { with } 5 \% \mathrm{Na}_{2} \mathrm{O}^{\circ}\end{array}$ \\
\cline { 2 - 3 } Sintering temperature & $\sim 1200^{\circ} \mathrm{C}$ & $-1100^{\circ} \mathrm{C}$ \\
Melt viscosity at $1600^{\circ} \mathrm{C}$ & $\sim 4000-500$ poise & $-5(\%)$ poise \\
\hline a. $\mathrm{Na}_{2} \mathrm{O}$ added as $\mathrm{Na}_{2} \mathrm{CO}_{3}$. & & \\
\hline
\end{tabular}

\section{A.2. Fusion Temperature}

The fusion temperature of various soils is given in Table A-3 and corresponds to the temperature at which its conductivity begins to increase at higher rates than the soil in its solid state (see References 1 and 2). The temperature at which the soil is completely liquified is assumed to) be -20()$^{\circ} \mathrm{C}$ higher than this initial fusion temperature. Fusion temperatures for all soils tested ranged from 1100 to $14000^{\circ} \mathrm{C}$.

Table A-3. Fusion temperatures of soils.

\begin{tabular}{lc}
\hline Site & $\begin{array}{c}\text { Fusion Temperature } \\
\left({ }^{\circ} \mathrm{C}\right)\end{array}$ \\
\cline { 2 - 2 } Barnwell & $14(0)$ \\
Hanford & 1100 \\
INEL & $11(0)$ \\
LANL & $1100(130)$ \\
ORNL & 1100 \\
\hline
\end{tabular}

\section{A.3. Thermal Conductivity}

Soil thermal conductivity varies with composition, density, and temperature. Although conductivity data are unavailable for INEL soils, measured values are available for soil samples taken from other Department of Energy (DOE)-operated sites. Representative values at ambient temperatures are given in Table $A-4$, while Figure A-1 illustrates the influence of temperature on conductivity. As indicated, soil conductivities ( $k$ ) at ambient temperature are low, ranging from 0.099 to $0.15 \mathrm{~W} / \mathrm{mK}$, but increase dramatically with increased temperature. 
Table A-4. Soil thermal conductivity at ambient temperature.

$\underline{\text { Site }}$ Thermal Conductivity, $\mathrm{W} / \mathrm{m}-\mathrm{K}$

Barnwell

0.151

Hanford

0.131

LANL

0.109

ORNL

0.104

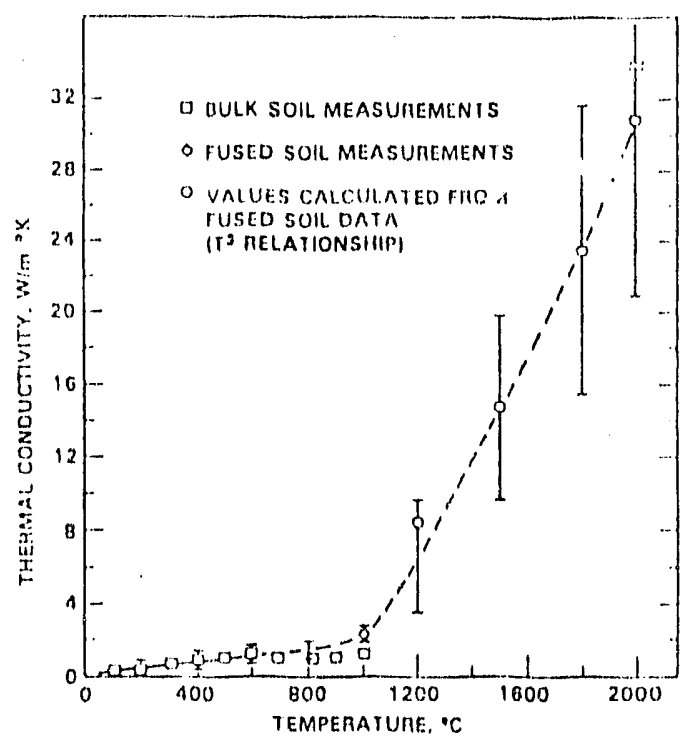

Figure A-1. Thermal conductivities of Hanford soil (see Reference 1).

\section{A.4. Specific Heat}

Measured values of the specific heat of Hanford soil are presented in Figure A-2, indicating a range of $0.19-0.22 \mathrm{cal} / \mathrm{g}^{\circ} \mathrm{C}$ (see Reference 1) at low temperatures and $0.25-0.28 \mathrm{cal} / \mathrm{g}^{\circ} \mathrm{C}$ at melt tcmperatures $\left(>1300^{\circ} \mathrm{C}\right)$.

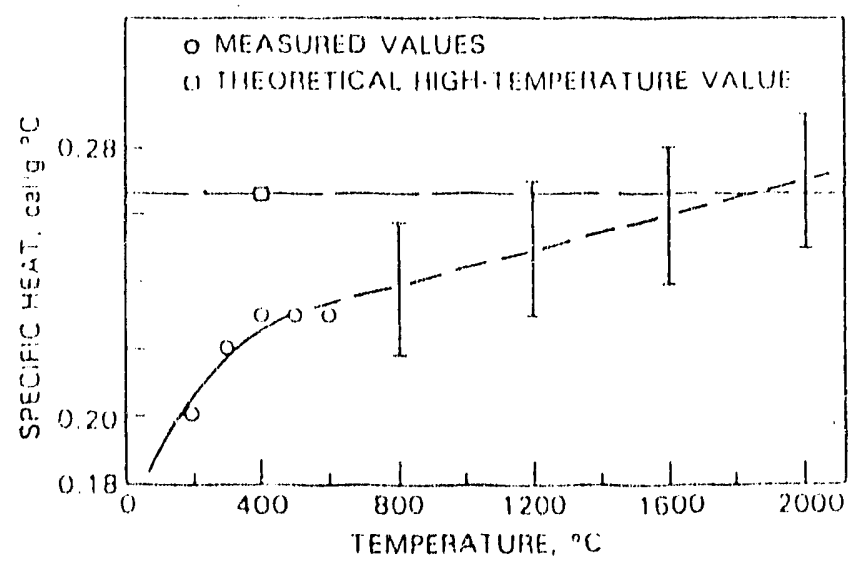

Figure 2. Specific heat of Hanford soil at various temperatures. 


\section{A.5 Soil Density}

Vitrified and resolidified soils exhibit densities in the range of $2.2-2.5 \mathrm{~g} / \mathrm{cm}^{3}$ (sec Reference 1), regardless of their initial densities. Table A-5 presents various measured values for several soil types subject to melting and refreezing, while Figure A-3 illustrates the manner in which soil density varies during ISV processing. As indicated, little density change $(1.65 \mathrm{~g} / \mathrm{cc})$ is noted until the soil begins to fuse at $-700-900^{\circ} \mathrm{C}$, at which point the density increases until the soil is completely fused at $\sim 140(1)^{\circ} \mathrm{C}$.

Table A-5. Bulk density of vitrified soil.

Site

\section{Vitrified Density, g/ce}

Hanford

2.43

LANL

2.33

Maxcy Flats

2.30

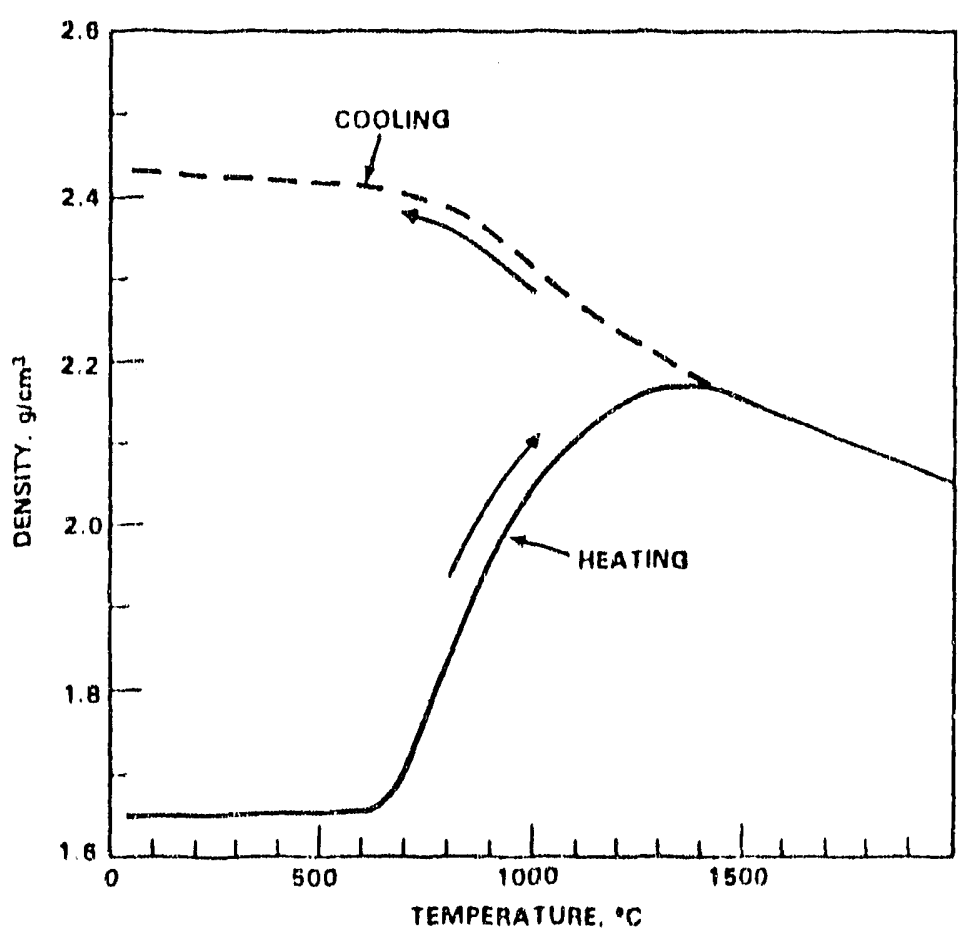

Figure A-3. Change in Hanford soil density during processing (sec Reference 1).

A decrease in density then occurs at higher temperatures, due to the thermal expansion of the rnaterial. During cooling, the density is shown to increase again as the melt contracts and solidifies, reaching a final value of $\approx 2.4-2.5 \mathrm{~g} / \mathrm{cc}$.

\section{A.6 Viscosity of Molten Soil}

Soils consist of basic and acidic oxide constituents, of which the most common acidic components are $\mathrm{SiO}_{2}$ and $\mathrm{Al}_{2} \mathrm{O}_{3}$, while $\mathrm{CaO}, \mathrm{FeO}$, and $\mathrm{MgO}$ are common basic components. Upon melting, the soil viscosity can be expected to vary with composition, since viscous flow occurs by 
breaking of microstructural bonds within the melt-that is, the bonds between the acidic and basic soil components. The effects of composition and temperature are illustrated in Figure $\mathrm{A}-4,{ }^{3}$ where the horizontal axis represents the sum of the molar content of $\mathrm{X}\left(\mathrm{SiO}_{2}\right)$ plus $\mathrm{X}_{\mathrm{a}}$, where $\mathrm{X}_{\mathrm{a}}$ depends on the total $\mathrm{Al}_{2} \mathrm{O}_{3}$ (alumina) content and $\mathrm{Al}_{2} \mathrm{O}_{3} / \mathrm{CaO}$ molar ratio. The salient point to note from Figure $\mathrm{A}-4$, is the wide variation in the viscosity of $\mathrm{CaO}-\mathrm{Al}_{2} \mathrm{O}_{3}-\mathrm{SiO}_{2}-\mathrm{MgO}$ based soils with composition. For example at melt lemperatures of about $1450^{\circ} \mathrm{C}$ (similar lo INLL soil melt temperatures) and low $\mathrm{CaO}$ content (represented by $\mathrm{X}_{\mathrm{SiO} 2}+\mathrm{X}_{\mathrm{a}}=0.4$ ), a viscosity of 4 poise is indicated $(\log \mu=0.6 ; \mu=4)$; while at high $\mathrm{CaO}$ content (represented by $\mathrm{X}_{\mathrm{SiO} 2}+\mathrm{X}_{\mathrm{a}}=0.8$ ) the viscosity is $25(0)$ poise $(\log \mu=3.4 ; \mu \approx 2500)$ ). Thus, almost a three order of magnitude variation in viscosity is evident with change in $\mathrm{CaO}$ content.

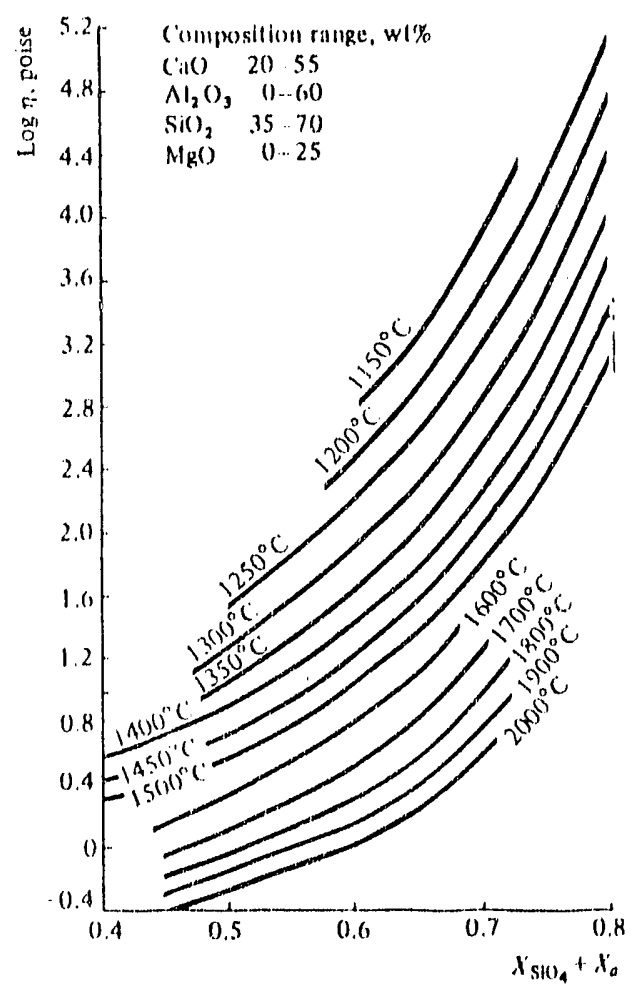

Figure A-4. Effect of composition and temperature on the viscosity of $\mathrm{SiO}_{2}-\mathrm{A}_{2} \mathrm{O}_{3}-\mathrm{CaO}-\mathrm{MgO}$ hased melts (see Reference 3 ).

Soil melt viscosities of several soil types are also shown in Figure A-5 (see Reference 1), indicating a wide range of values as well as a decrease in viscosity with increasing temperature. The higher content of $\mathrm{Fe}_{2} \mathrm{O}_{3}$ in the Hanford soil is thought to have contributed to its lower viscosity at similar temperatures as ihe other soils. For present purposes, Hanford viscosity values are used for INEL soils, that is $\approx 300$ poise at soil melt temperatures of $1450^{\circ} \mathrm{C}$.

\section{A.7 Melt Surface Tension}

Since measurements for the surface tension (o) of INEL soil melts are unavailable, values for $\mathrm{Al}_{2} \mathrm{O}_{3}\left(\sigma=840 \mathrm{dy} / \mathrm{cm},{ }^{4}\right.$ and $\mathrm{UO}_{2}\left(\sigma=1000 \mathrm{dy} / \mathrm{cm},{ }^{5}\right.$ are employed. For present purposes a value of $\mathrm{I}(\mathrm{KK}) \mathrm{dy} / \mathrm{cm}$ is assumed for $\mathrm{SiO}_{2}-\mathrm{A}_{2} \mathrm{O}_{3}-\mathrm{CaO}-\mathrm{MgO}$ based melis. 


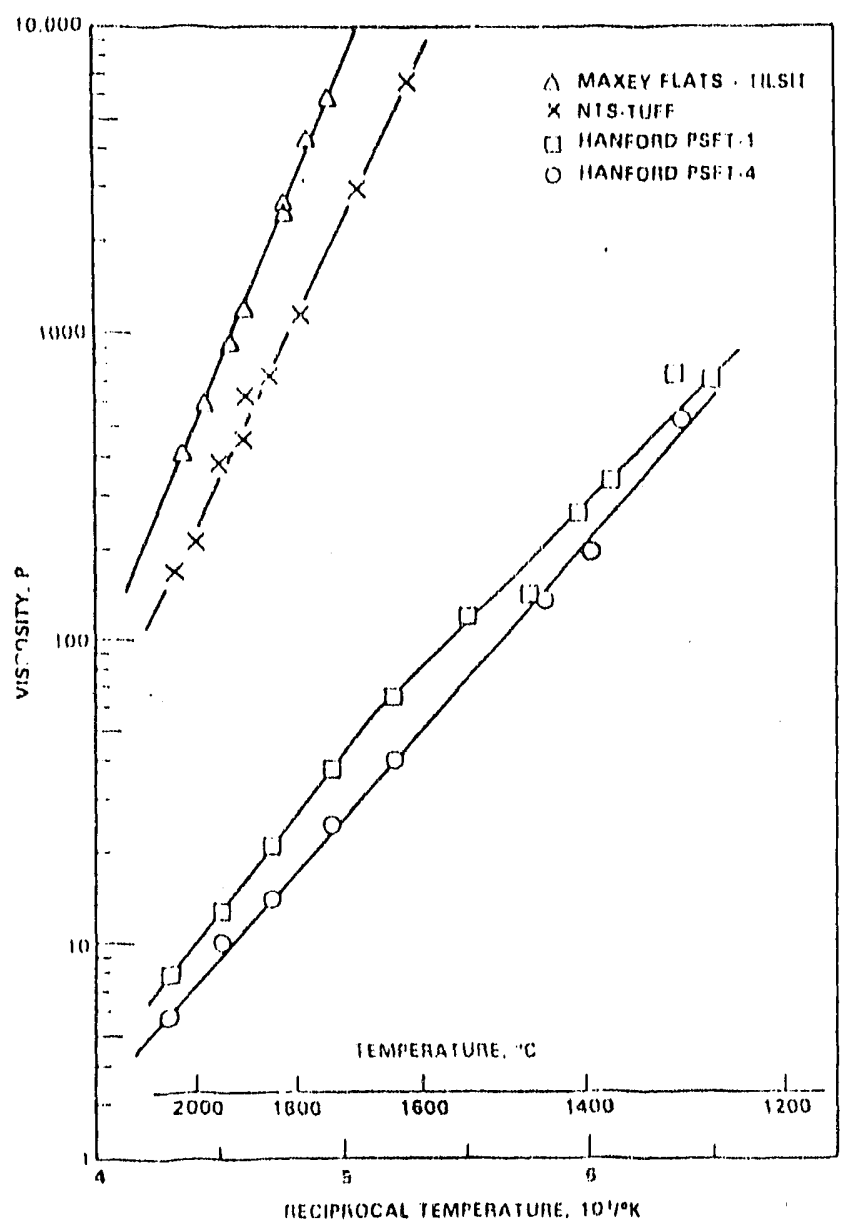

Figure A-5. Viscosities of molten soils (see Reference 1).

\section{A.8 Summary}

Table A-6 summarizes soil melt properties used within the body of this report.

Table A-6. Summary of soil melt properties.

\section{Properly}

Soil Composition (wt-\%)

Melt Temperature $\left(\mathrm{T}_{\mathrm{mp}}\right)$

Melt Densily $(\rho)$

Mclt Viscosity $(\mu)$

Kinematic Viscosity $\left(\mu_{k}=\mu / \rho\right)$

Melt Conductivity (k)

Melt Specific Heat $\left(C_{p}\right)$

Thermal Diffusivity $\left(\alpha=k / \rho C_{p}\right)$

Melt Surlace Tension ( $\sigma)$
Value

$62-\mathrm{SiO}_{2} / 12-\mathrm{Al}_{2} \mathrm{O}_{3} / 5-\mathrm{Fe}_{2} \mathrm{O}_{3} / 2($ )-other

$1447^{\circ} \mathrm{C}(1720 \mathrm{~K})$

$2.2 \mathrm{~g} / \mathrm{cm}^{3}$

300 poise

$136 \mathrm{~cm}^{2} / \mathrm{s}$

$0.0335 \mathrm{cal} / \mathrm{s}-\mathrm{cm}-\mathrm{K}\left(14 \mathrm{~W} / \mathrm{m}-\mathrm{K}^{\prime}\right)$

$0.26 \mathrm{cal} / \mathrm{g}-\mathrm{K}$

$0.0586 \mathrm{~cm}^{2} / \mathrm{s}$

$1000 \mathrm{dy} / \mathrm{cm}$ (assumed) 


\section{A.9 References}

1. J. L. Buelt et al., "In Situ Vitrification of Transuranic Wastes: An Updated Systems Evaluations and Applications Assessment," PNL-4800 (Suppl. 1), Pacific Northwest Laboratory, Richland, WA, March 1987.

2. K. H. Oma, M. A. H. Reimus, and C. L. Timmerman, "Support for the In Situ Vitrilication Treatability Study at the Idaho National Engineering Laboratory: FY 1988 Summary," PNL-6787, Pacific Northwest Laboratory, Richland, WA, February 1989.

3. G. H. Geiger and D. R. Poirier, Transport Phenomena in Metallungy, Addison-Wesley Publishing Co., Reading MA, pp. 23-30, 1973.

4. A. G. Guy and J. J. Hren, Elements of Physical Metallurgy, Addison-Wesley Publishing Co., Reading MA, p. 274, 1974.

5. D. R. Olander, Fundamental Aspects of Nuclear Reactor Fuel Elements, Department of Energy Publication, p. 203, 1976. 


\section{Appendix B}

\section{Diffusivity Estimates for Mass Transport Analysis}


B-2 


\section{Appendix B}

\section{Diffusivity Estimates for Mass Transport Analysis}

Since molecular transport of various species through liquids largely depends on their diflusivity $\left(D_{a, 1}\right)$ within melt, knowledge of diffusion propertics is of primary importance to the prediction of overall transport behavior. This is true whether the governing process is direct diffusion, natural convection, or by carry-off of escaping gas bubbles; the primary dimensionless groupings for characterization of such transport processes are:

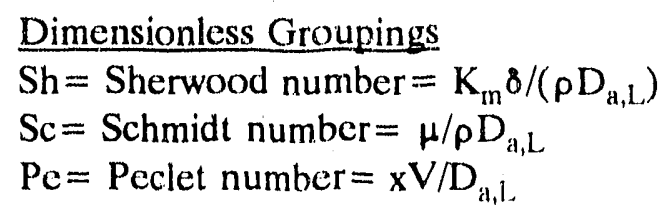

where

$$
\begin{aligned}
& \mathrm{K}_{\mathrm{m}}=\text { mass transfer coefficient } \\
& \mathrm{x}_{10}=\text { distance parameters } \\
& \rho=\text { melt density } \\
& \mathrm{D}_{\mathrm{a}, \mathrm{l}}=\text { molecular diffusivity of species-a in liquid } \\
& \mu=\text { melt viscosity } \\
& \mathrm{V}=\text { velocity } \\
& \mathrm{o}=\text { melt surface tension. }
\end{aligned}
$$

Unfortunately, data is not available for the diffusivities of the rare-earth and Pu oxides in soil-based melts; thus, predictive models are examined here for estimation of such diffusivities.

\section{B.1 Overview of Molecular Diffusivities in Liquid}

Of the three thermodynamic states (solid, liquid, and vapor), the liquid state is the least understond and least amenable to mathematical modeling. This problem is due to the fact that the structure of a liquid, on a molecular scale, is considerably more difficult to visualize than the randomness associated with gases, or the regularity of atomic arrangement found in solids. In theory, liquids maintain a structure which is a compromise between order and disorder, for which exact modeling is difficult.

Owing to the fact that no satisfactory theory of the liquid state has been developed, it is impossible to provide an exact picture of molecular diffusion in liquids. Nevertheless, empirical data 
have established the remarkable characteristic that liquids with low viscositic: (<1 poise) exhibit similar molecular diffusivities on the order of $10^{-5} \mathrm{~cm}^{2} / \mathrm{s}$, even though their solid state properties may be quite different. In the absence of measured values for $D_{a, L}$, empirically-based models are examined to estimate the diffusivities for $\mathrm{Dy}_{2} \mathrm{O}_{3}, \mathrm{~Tb}_{4} \mathrm{O}_{7}, \mathrm{Yb}_{2} \mathrm{O}_{3}$ and $\mathrm{PuO}_{2}$, namely the SutherlandEinstein, Wilke-Chang, and Scheibel models.

\section{B.2 Sutherland-Einstein Diffusivity Model}

One of the more successful approaches for estimating the diffusivity of an individual solute atom or molecule in a liquid is via the Sutherland-Einstein model: ${ }^{1}$

$D_{a, L}=\left[\frac{k T}{6 \pi \mu_{L} r_{a}}\right]\left[\frac{1+\left(3 \mu_{L} / \beta r_{a}\right)}{1+\left(2 \mu_{L} / \beta r_{a}\right)}\right]$

where

$D_{a, L}=$ the diffusion coefficient of solute molecule (a) in solvent (L)

$\mathrm{k}=$ Boltzmann's constant

$r_{\mathrm{a}}=$ molecular radius of the diffusing species

$\mathrm{T}=$ absolute temperature

$\beta=$ molecular friction coefficient which increases with the size of the diffusing species

$\mu_{\mathrm{I}}=$ the dynamic viscosity of the solvent.

In the extreme limits where $\beta=O$ and $\beta=\infty$, Equation (B-1) reduces to:

$D_{a, 1}=\frac{k T}{4 \pi r_{a} \mu_{1}} \quad$ if $\beta=0$

$D_{i, 1}=\frac{k T}{6 \pi r_{a} \mu_{L}} \quad$ if $\beta=\infty$

Inspection of Equation (B-3) indicates that the parameter influencing species diffusivity is its molecular radius $\left(\mathrm{r}_{\mathrm{a}}\right)$. As discussed in Reference 2 , molecule size is a difficult property to determine One factor is that electronic probability distribution never becomes exactly zero; thus, the distance designated as the boundary of the atom is an arbitrary choice. Likewise, the electronic configuration is affected by neighboring atoms; hence the size of the atom constituent may change from one 
compound to another. Since data on molecular size are unavailable for the rare-earth tracers $\left(\mathrm{Dy}_{2} \mathrm{O}_{3}\right.$, $\mathrm{Tb}_{4} \mathrm{O}_{7}$, and $\mathrm{Yb}_{2} \mathrm{O}_{3}$ ) used in the INEL-ISV studies, an alternate approach is chosen for estimation of $D_{i, 1}$.

\section{B.3 Wilke-Chang Diffusivity Model}

Wilke and Chang (see References 1 and 2) have suggested the following semi-cmpirical model for prediction of molecular diffusivities in liquids, where the diffusivity depends on the more readily definable molar volume:

$\left.D_{a, L}\left(\mathrm{~cm}^{2} / \mathrm{s}\right)=1.28 \mathrm{E}-7 \mathrm{~T} \mid \frac{\mathrm{M}^{1 / 2}}{\mu_{\mathrm{L}} \mathrm{V}^{0.6}}\right\rceil$

where

$M=$ molecular weight of the solvent $M(\mathrm{~g} / \mathrm{mole})$

$\mathrm{T}=$ absolute temperature $\mathrm{T}(\mathrm{K})$

$\mu_{1}=$ viscosity of the liquid (cP)

$V=$ molar volume of the solute molecuse $\left(\mathrm{cm}^{3} / \mathrm{mole}\right)$.

Table B-1 presents the required molar properties of the diffusing species ( $\mathrm{Dy}_{2} \mathrm{O}_{3}, \mathrm{~Tb}_{4} \mathrm{O}_{7}, \mathrm{Y}_{2} \mathrm{O}_{3}$, and $\mathrm{PuO}_{2}$ ), white Table $\mathrm{B}-2$ presents predicted results using the Wilke-Chang model. As indicated, the diffusivities predicted using the Wilke-Chang model are approximately $10^{-8} \mathrm{~cm}^{2} / \mathrm{s}$, which are about iwo orders-of-magnitude less than the self-diffusivities for the common slags $\left(10^{6} \mathrm{~cm}^{2} / \mathrm{s}\right.$; see Table B-.3). ${ }^{3}$ Since the diffusivities predicted using the Wilke-Chang model are suspect, an alternate makdel is investigated, Scheibel's model. 
Table B-1. Tracer and soil molecular propertıes.

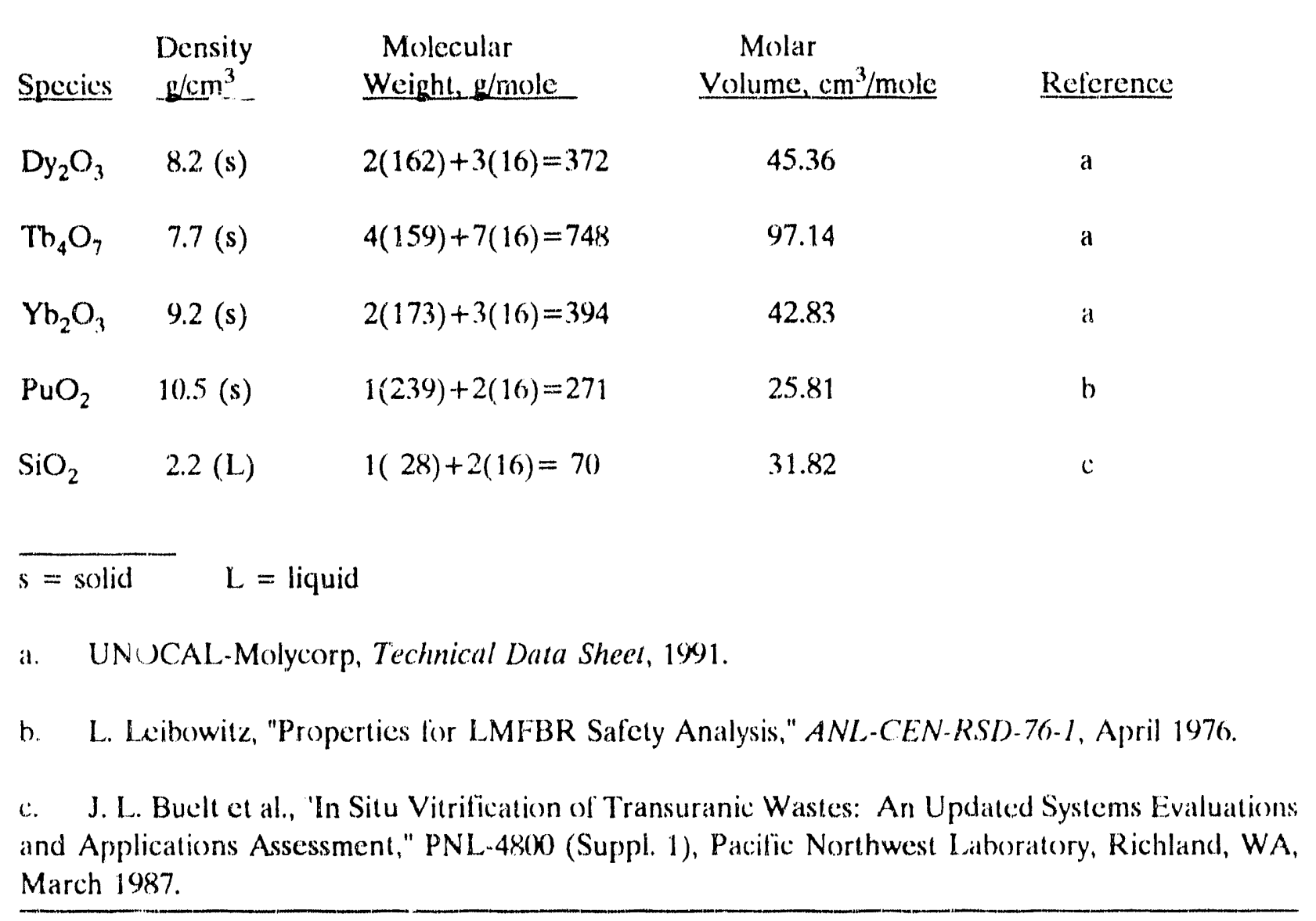

Table B-2. Tracer and $\mathrm{PuO}_{2}$ diffusivities using Wilke-Chang model.

$\mathrm{D}_{\mathrm{a}, \mathrm{L}, \mathrm{cm}}\left(\mathrm{cm}^{2} / \mathrm{s}\right)=1.28 \mathrm{E}-7 \mathrm{~T}\left[\frac{\mathrm{M}^{1 / 2}}{\mu_{1} \mathrm{~V}^{0.6}}\right]$

Propertics of $\mathrm{SiO}_{2}$ Mclt

$$
\begin{aligned}
& \mathrm{M}=\text { molecular weight }=70 \mathrm{~g} / \mathrm{molc}, \\
& \mathrm{T}=\text { melt temperature }=1720 \mathrm{~K}, \\
& \mu_{1}=\text { melt viscosity }=300 \mathrm{poisc}=3.0 \mathrm{E}+4 \mathrm{cP}, \\
& \mathrm{A}=1.28 \mathrm{E}-7(\mathrm{~T})\left(\mathrm{M}^{1 / 2}\right) / \mu_{1}=6.14 \mathrm{E}-8
\end{aligned}
$$

\begin{tabular}{|c|c|c|c|}
\hline Species & $V_{1} \mathrm{~cm}^{3} /$ mole & $V^{+10}$ & $\mathrm{D}_{1} \mathrm{~cm}_{3} / \mathrm{s}$ \\
\hline $\mathrm{Th}_{1} \mathrm{O}_{7}$ & 97.14 & 15.57 & $0.394 \mathrm{E}-8$ \\
\hline $\mathrm{D}_{2} \mathrm{O}_{3}$ & 45.36 & 9.86 & $0.623 \mathrm{E}-8$ \\
\hline $\mathrm{Yb}_{2} \mathrm{O}_{3}$ & 42.83 & 9.53 & $0.644 \mathrm{E}-8$ \\
\hline $\mathrm{PuO}_{2}$ & 25.81 & 7.97 & $0.770 \mathrm{E}-8$ \\
\hline
\end{tabular}

where in this case the molar volume of the solute $\left(V_{a}\right)$ is that of Fe: 
Table B-3. Diffusivities in molten silicates.

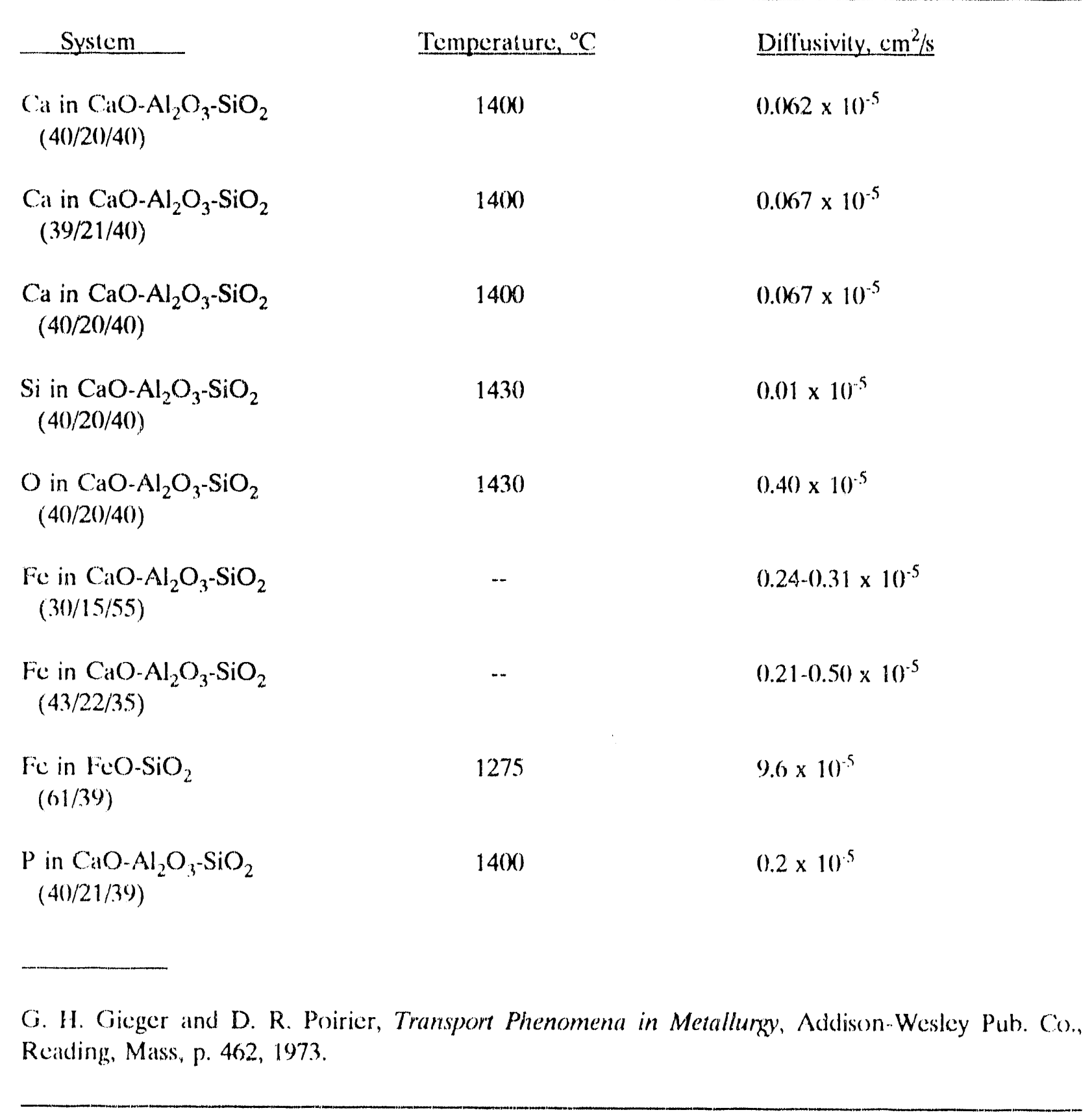




\section{B.4 Schelbel's Diffusivity Model}

Scheibel (see References 1 and 4 ) has suggested a model where the diffusivity depends on the molar volumes of both the solute $\left(\mathrm{V}_{\mathrm{a}}\right)$ and solvent $\left(\mathrm{V}_{\mathrm{b}}\right)$, as well as the melt viscosity $\left(\mu_{\mathrm{L}}\right)$, where property units are the same as used in the Wilke-Chang model:

$$
\mathrm{D}\left(\mathrm{cm}^{2} / \mathrm{s}\right)=\left(\frac{8.2 \mathrm{E}-8 \mathrm{~T}}{\mu\left(\mathrm{V}_{\mathrm{a}}\right)^{1 / 3}}\right)\left[1+\left(\frac{3 \mathrm{~V}_{\mathrm{b}}}{\mathrm{V}_{\mathrm{a}}}\right)^{2 / \mathrm{s}}\right]
$$

Table B-4 presents calculational results using the molar volumes given in Table B-1. As indicated, the diffusivities are again estimated to be on the order of $10^{-8} \mathrm{~cm}^{2} / \mathrm{s}$, similar to values predicted by the Wilke-Chang model. These low diffusivity estimates appear to result from the rather high viscosity used for molten soils ( 300 poise versus 0.01 poise for water), so that the numerical coefficients used in these empirical models appear inappropriate for high viscosity liquids. Thus, a scaling approach is employed, as outlined in the following section.

Table B-4. Tracer and $\mathrm{PuO}_{2}$ diffusivities using Scheibel's model.

$$
\mathrm{D}\left(\mathrm{cm}^{2} / \mathrm{s}\right)=\left(\frac{8.2 \mathrm{E}-8 \mathrm{~T}}{\mu\left(\mathrm{V}_{\mathrm{a}}\right)^{1 / 3}}\right)\left[1+\left(\frac{3 \mathrm{~V}_{\mathrm{b}}}{\mathrm{V}_{\mathrm{a}}}\right)^{2 / 3}\right]
$$

\section{Properties of $\mathrm{SiO}_{2}$ Melt}

\begin{tabular}{|c|c|c|c|c|c|}
\hline Species & $\underline{V}_{\mathrm{a}} \mathrm{cm}^{3} / \mathrm{mole}$ & $\underline{V}_{j}^{1 / 3}$ & $\mathrm{~A} / \mathrm{V}_{\mathrm{a}}{ }^{1 / 3}$ & $B$ & $D_{1} \mathrm{~cm}^{2} / \mathrm{s}$ \\
\hline $\mathrm{Tb}_{4} \mathrm{O}_{7}$ & 97.14 & 4.596 & $1.02 \mathrm{E}-9$ & 1.988 & $0.203 \mathrm{E}-8$ \\
\hline $\mathrm{Dy}_{2} \mathrm{O}_{3}$ & 45.36 & 3.566 & $1.32 \mathrm{E}-9$ & 2.64 & $0.349 \mathrm{E}-8$ \\
\hline $\mathrm{Yb}_{2} \mathrm{O}_{3}$ & 42.83 & 3.498 & $1.34 \mathrm{E}-9$ & 2.706 & $0.363 \mathrm{E}-8$ \\
\hline $\mathrm{PuO}_{2}$ & 25.81 & 2.955 & $1.59 \mathrm{E}-9$ & 3.39 & $0.539 \mathrm{E}-8$ \\
\hline
\end{tabular}

$$
\begin{aligned}
& \mathrm{V}_{\mathrm{b}}=\text { solvent molal volume }\left(\mathrm{SiO}_{2}\right)=31.82 \mathrm{~cm}^{3} / \mathrm{mole}, \\
& \mathrm{T}=\text { melt temperature }=1720 \mathrm{~K}, \\
& \mu_{\mathrm{L}}=\text { melt viscosity }=300 \text { poise }=3.0 \mathrm{E}+4 \mathrm{cP}, \\
& \mathrm{A}=8.2 \mathrm{E}-8(\mathrm{~T}) /\left(\mu_{\mathrm{L}}\right)=4.70 \mathrm{E}-9 \\
& \mathrm{~B}=\left[1+\left(3 \mathrm{~V}_{\mathrm{b}} / \mathrm{V}_{\mathrm{a}}\right)^{2 / 3}\right]
\end{aligned}
$$




\section{B.5 Modified Scheibel's Model}

Although the Wilke-Chang and Scheibel models yield reasonable results for common liquids with low viscosities (water $\approx 0.01$ poise), the ecelficients they suggest do not apply for complex melts with rather high viscosities $\left(\mathrm{SiO}_{2}-\mathrm{Al}_{2} \mathrm{O}_{3}-\mathrm{CaO} \approx 300\right.$ poise). Since data are lacking on tracer and $\mathrm{PuO}_{2}$ diffusivitics in $\mathrm{SiO}_{2}$-based melts, and since standard models appear inappropriate for predicting D for soil melts, a scaling approach is employed. In this approach the diffusivity suggested for iron ( $\mathrm{Fc}=$ $0.25 \times 10^{-5} \mathrm{~cm}^{2} / \mathrm{s}$; see Table B-3) is used since it represents a dilute species which is different from the main soil constituents $\left(\mathrm{SiO}_{2}, \mathrm{Al}_{2} \mathrm{O}_{3}, \mathrm{CaO}\right)$, as is the case for the tracer oxides and $\mathrm{PuO}_{2}$. Here it is assumed that the general form of Scheibel's model applies, where the coefficient (X) is estimated from diffusivity data for $\mathrm{Fe}$ :

$D\left(\mathrm{~cm}^{2} / \mathrm{s}\right)=0.25 \mathrm{E}-5=\left(\frac{\mathrm{XT}}{\mu\left(\mathrm{V}_{\mathrm{a}}\right)^{1 / 3}}\right)\left[1+\left(\frac{3 \mathrm{~V}_{\mathrm{b}}}{\mathrm{V}_{\mathrm{a}}}\right)^{2 / 3}\right]$

where in this case the molar volume of the solute $\left(\mathrm{V}_{\mathrm{a}}\right)$ is that of $\mathrm{Fe}$ :

$$
\begin{aligned}
& V_{a}=\text { molar volume of iron }(\mathrm{Fe}) \text { solute }=7.12 \\
& \mathrm{~V}_{\mathrm{b}}=\text { molar volume of liquid solvent }=31.82 \\
& \mu_{\mathrm{L}}=\text { viscosity }=3.0 \mathrm{E}+4 \mathrm{cP} \\
& \mathrm{X}=\text { scaling coefficient. }
\end{aligned}
$$

Solution of the above equation for the scaling cocficient $(X)$, is given in Table B-5, yielding a value of $\mathrm{X}=1.263 \mathrm{E}-5$. Thus, the modified Scheibel equation for molten $\mathrm{SiO}_{2}$-based soils becomes:

$D\left(\mathrm{~cm}^{2} / \mathrm{s}\right)=\left(\frac{1.263 \mathrm{E}-5 \mathrm{~T}}{\mu\left(\mathrm{V}_{\mathrm{a}}\right)^{1 / 3}}\right)\left[1+\left(\frac{3 \mathrm{~V}_{\mathrm{b}}}{\mathrm{V}_{\mathrm{a}}}\right)^{2 / 3}\right]$

Table B-6 presents calculational results for the "modified Scheibel," scaled to the known Fe diffusivity in $\mathrm{SiO}_{2}$-based melts. Diffusivity values on the order of $10^{-6} \mathrm{~cm}^{2} / \mathrm{s}$ are indicated, which compare well with values cited in the literature for $\mathrm{SiO}_{2}$-based melts (sec Table B-3). Based on agreement of predicted results using the "modified Scheibel" equation with published diffusivities for mollen slags, the diffusivities for tracer and $\mathrm{PuO}_{2}$ species used in this report are taken to be those predicted from the "modilied Scheibel" equation (see Table B-6). 
Table B-5. Estimation of coefficient for modified Scheibel model.

$\mathrm{D}\left(\mathrm{cm}^{2} / \mathrm{s}\right)=0.25 \mathrm{E}-5=\left(\frac{\mathrm{XT}}{\mu\left(\mathrm{V}_{\mathrm{a}}\right)^{1 / 3}}\right)\left[1+\left(\frac{3 \mathrm{~V}_{\mathrm{b}}}{\mathrm{V}_{\mathrm{a}}}\right)^{2 / 3}\right]$

\section{Properties}

$\mathrm{V}_{\mathrm{a}}=$ solute molar volume $(\mathrm{Fe})=7.12 \mathrm{~cm}^{3} / \mathrm{mole}$,

$V_{b}=$ solvent molar volume $\left(\mathrm{SiO}_{2}\right)=31.82 \mathrm{~cm}^{3} / \mathrm{mole}$,

$\mathrm{T}=$ melt temperature $=1720 \mathrm{~K}$,

$\mu_{\mathrm{L}}=$ melt viscosity $=300$ poisc $=3.0 \mathrm{E}+4 \mathrm{cP}$,

$\mathrm{A}=(0.25 \mathrm{E}-5)\left(\mu_{\mathrm{L}}=3.0 \mathrm{E}+4\right)\left(\mathrm{V}_{\mathrm{a}}=7.12^{1 / 3}\right)=8.389 \mathrm{E}-5$

$\mathrm{B}=\left[1+\left(3 \mathrm{~V}_{\mathrm{b}} / \mathrm{V}_{\mathrm{a}}\right)^{2 / 3}\right]=6.644$

$\mathrm{X}=\mathrm{A} / \mathrm{B}=1.263 \mathrm{E}-5$

Modified Scheibel Equation

$\left.\mathrm{D}\left(\mathrm{cm}^{2} / \mathrm{s}\right)=\left(\frac{1.263 \mathrm{E}-5 \mathrm{~T}}{\mu\left(\mathrm{V}_{\mathrm{a}}\right)^{1 / 3}}\right) \mid 1+\left(\frac{3 \mathrm{~V}_{\mathrm{b}}}{\mathrm{V}_{\mathrm{a}}}\right)^{2 / 3}\right]$

Table B-6. Tracer diffusivities using modified Scheibel model.

$\mathrm{D}\left(\mathrm{cm}^{2} / \mathrm{s}\right)=\left(\frac{1.263 \mathrm{E}-5 \mathrm{~T}}{\mu\left(\mathrm{V}_{\mathrm{a}}\right)^{1 / 3}}\right)\left[1+\left(\frac{3 \mathrm{~V}_{\mathrm{b}}}{\mathrm{V}_{\mathrm{a}}}\right)^{2 / 3}\right]$

Properties of $\mathrm{SiO}_{2}$ Melt

$\mathrm{V}_{\mathrm{b}}=$ solvent molal volume $\left(\mathrm{SiO}_{2}\right)=31.82 \mathrm{~cm}^{3} / \mathrm{mole}$,

$\mathrm{T}=$ melt temperature $=1720 \mathrm{~K}$,

$\mu_{L}=$ melt viscosity $=300$ poise $=3.0 \mathrm{E}+4 \mathrm{cP}$,

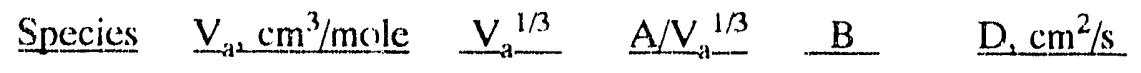

$\begin{array}{llllll}\mathrm{Tb}_{4} \mathrm{O}_{7} & 97.14 & 4.596 & 1.58 \mathrm{E}-7 & 1.988 & 0.313\end{array}$

$\mathrm{Dy}_{2} \mathrm{O}_{3} \quad 45.36 \quad 3.566 \quad 2.03 \mathrm{E}-7 \quad 2.64 \quad 0.536 \mathrm{E}-6$

$\begin{array}{llllll}\mathrm{Yb}_{2} \mathrm{O}_{3} & 42.83 & 3.498 & 2.07 \mathrm{E}-7 & 2.706 & 0.560 \mathrm{E}-6\end{array}$

$\begin{array}{llllll}\mathrm{PuO}_{2} & 25.81 & 2.955 & 2.45 \mathrm{E}-7 & 3.39 & 0.831 \mathrm{E}-6\end{array}$




\section{B.6 References}

1. S. Bretsznajder, Prediction of Transport and Other Physical Properties of Fluids, Pergamon Press, Oxford, 1971.

2. C. R. Wilke and P. Chang, J. Am. Inst. Chem. Engr. (1), p. 26, 1955.

3. G. H. Geiger and D. R. Poirier, Transport Phenomena in Metallurgy, Addison-Wesley Publ. Co., Reading, MA, 1973.

4. E. G. Schcibel, Ind. Engr. Chem. (46), p. 2007, 1954. 

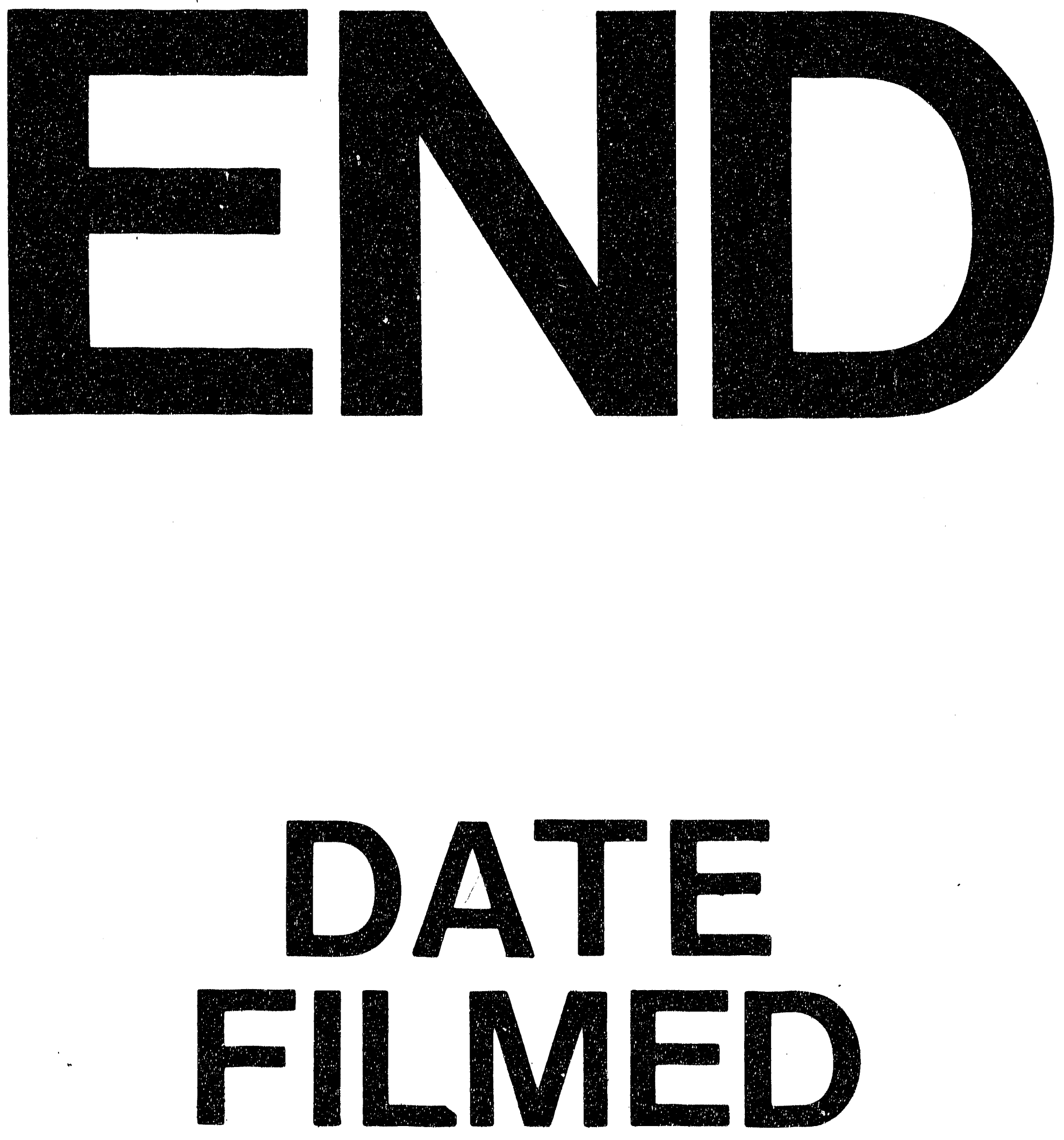

䙵

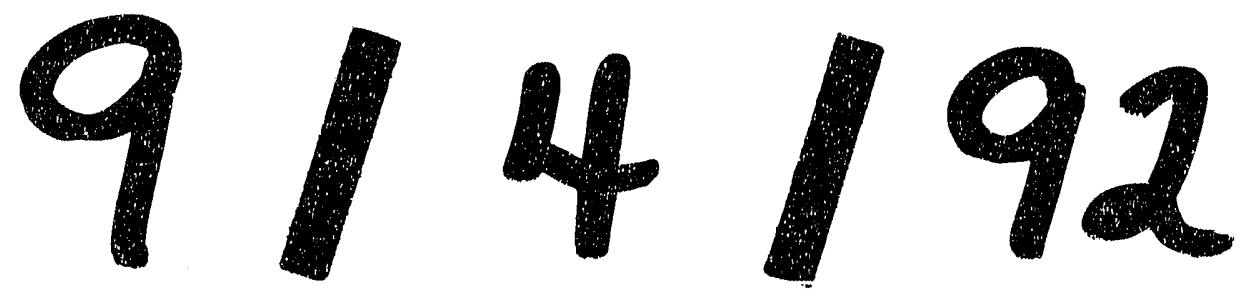


